Naomi Bennett

Peace Unwoven:

\title{
Transgressive Women in Old Icelandic Heroic and Mythological Literature, and in Saxo \\ Grammaticus' \\ Gesta Danorum.
}

\author{
A thesis \\ submitted to the Victoria University of Wellington \\ in fulfilment of the requirements for the degree of \\ Master of Arts in English Literature.
}

School of English, Film, Theatre and Media Studies.

Victoria University of Wellington 


\section{Acknowledgements}

A great deal of thanks goes to my supervisor, teacher and mentor, Dr Christine Franzen, for introducing me to Old Icelandic literature, and for her constant enthusiasm and encouragement. Thank you so much for all your time and effort, and your belief in me.

Thanks also to my long-suffering office-mates, Saskia Voorendt, Lujan Herrera and Sonia Johnson, for the time spent street-watching, coffee drinking and musing about literature. It has been fun!

Thanks especially to my family and to my husband Tom. Without your patience and love this thesis would never have happened.

Naomi Bennett, June 2009. 


\section{Abbreviations and Referencing}

\section{$\underline{\text { Abbreviations }}$}

Due to the number of texts referred to in this thesis, after the first citation a short title is used in the text (see below).

Texts

Fornaldarsögur

Ásmundar saga kappabana

Bósa saga ok Herrauðs

Egils saga einhenda ok Ásmundar berserkjabana

Eireks saga víðdförla

Frá Fornjóti ok hans ættmönnum

Friðpjófs saga ins frœkna

Gautreks saga

Gríms saga loðinkinna

Göngu-Hrólfs saga

Hálfdanar saga Eysteinssonar

Hálfs saga ok Hálfsrekka

Hervarar saga ok Heiðreks

Hrólfs saga Gautrekssonar

Hrólfs saga kraka

Hrómundar saga Gripssonar

Illuga saga Gríðarfóstra

Ketils saga hœngs

Örvar-Odds saga

Ragnars saga loðbrókar

Völsunga saga

Yngvars saga víðförla

Porsteins saga Víkingssonar

Af Upplendinga konungum

Pattir

Helga pattr Pórissonar

Norna-Gests páttr

Ragnarssona páttr

Sörla páttr

Tóka páttr Tókasonar

Völsa páttr

Porsteins páttr bæjarmagns

Riddarasögur

Hærra Ivan

Möttuls saga

Ívens saga

Parcevals saga

Valvens páttr

Erex saga

\section{Short titles}

Asmund

Bosi and Herraud

Egil and Asmund

Eirek

Fornjoti

Fridthjof

Gautrek

Grim Shaggy-Cheek

Gongu-Hrolf

Halfdan Eysteinsson

Half

Heidrek

Hrolf Gautreksson

Hrolf Kraki

Hromund

Illugi

Ketil Trout

Arrow-Odd

Ragnar L

Volsungs

Yngvar

Thorstein Vikingsson

Upplending

Helgi Thorisson

Norna-Gest

Ragnarssons

Sorli

Toki

Volsi

Thorstein

Haerra

Mottul

Iven

Parceval

Valven

Erex 
Skikkju rímur

Geitarlauf

Janual

Tristrams saga ok Ísöndar

Tristrams kvæði

Saga af Tristram ok Ísodd
Skikkjurimur

Geitarlauf

Janual

Tristram ok Isondar

Tristram's kvaedi

Tristram and Isodd

Mythology

Prose Edda

- Gylfaginning

- Skáldskaparmál

Gylfaginning

- Háttatal

Skalds

Hattatal

Heimskringla

- Ynglinga Saga

Poetic Edda

Yngling

- Völuspá (The Seeress' Prophecy)

Voluspa

Havamal

- Hávamál (Sayings of the High One)

Vafthrudnir

- Vafprúðnismál (Vafthrudnir's Sayings)

Grimnismal

- Grímnismál (Grimnir's Sayings)

Skirnir

- Skírnismál (Skirnir's Journey)

Harbard

- Hárbarðsljóð (Harbard's Song)

Hymir

- Hymiskviða (Hymir's Poem)

Loki

- Lokasenna (Loki's Quarrel)

Thrym

Volund

- Völundarkviða (The Lay of Volund)

Alvissmal

- Alvíssmál (All-Wise’s Sayings)

- Helgakviða Hundingsbana I (1st Poem of Helgi Hundinsbani)Helgi I

- Helgakviða Hjörvarðssonar (The Poem of Helgi Hiorvardsson)Helgi Hi

- Helgakviða Hundingsbana II(2nd Poem of Helgi Hundingsbani)Helgi II

- Frá Dauða Sinfjötli (The Death of Sinfjotli)

Sinfjotli

- Grípisspá (Gripir's Prophecy)

- Reginsmál (The Lay of Regin)

Gripisspa

- Fáfnismál (The Lay of Fafnir)

Regin

- Sigrdrífumál (The Lay of Sigrdrifa)

Fafnir

- Sigurðarkviða in meiri (Fragment of a Poem about Sigurd) Sigurd meiri

Sigurd sk

- Sigurðarkviða in skamma (A Short Poem about Sigurd)

Brynhild

- Helreið Brynhildar (Brynhild's Ride to Hell)

Niflungs

- Dráp Niflunga (The Death of the Niflungs)

Gudrun II

- Guðrúnarkviða in forna (The Second Lay of Gudrun)

Gudrun III

- Guðrúnarkviða in priðja (The Third Lay of Gudrun)

Oddrun

- Oddrúnarkviða (Oddrun's Lament)

- Atlakviða (The Lay of Atli)

- Atlamál in grænlenzku (The Greenlandic Poem of Atli)

Atlakvida

Atlamal

- Guðrúnarhvöt (The Whetting of Gudrun)

- Hamðismál (The Lay of Hamdir)

Gudrunahvot

- Baldrs draumar (Baldr's Dreams)

Hamdir

Baldr

- Rígspula (The List of Rig)

Rig

- Hyndluljóð (The Song of Hyndla)

Hyndla 


\section{$\underline{\text { Referencing }}$}

Each text is fully referenced on its first occurrence in the footnotes, with Old Icelandic title, chapter, and publication details, both in the original language and in translation. Translations are referenced before editions. Subsequent short references are in-text, unless a quotation is used.

\section{Gesta Danorum}

This is referenced according to chapter and page, both in the translation and in the edition. Translation page numbers are square-bracketed.

\section{Fornaldarsögur}

As I have used online editions, after the initial citation I use a short title, chapter, and page number of the translation. Byock has his own chaptering system. Where this differs from the editions, his chapters are square-bracketed.

\section{Riddarasögur}

After the first reference I use a short title, chapter or line number where relevant, and page numbers. The edition and translation are on facing pages.

\section{Eddas and Heimskringla}

These are referenced by page number in the translations, and chapters of the editions. 


\section{Note on the translations}

Due to the volume of texts I have read for this thesis, most of my reading has been in translation. Because of this, I am using the translations in my main text, with the original Latin or Old Icelandic in the footnotes. Hopefully this will increase the readability of this thesis for people who are not fluent readers of Old Icelandic in particular. Most of the translations I have used are published, although some I have only been able to source on the internet. Specific terms have been checked against the original Old Icelandic where deemed necessary. While these translations, published and unpublished, may not always be entirely literal, they have been an extremely useful way of coming to terms with the fornaldarsögur corpus. Had I needed to translate them myself, this thesis would not have happened.

\section{Orthographical note}

Instead of 'hooked o', the online editions I have consulted use ö, as has been standard practice for some time, including in modern Icelandic. I have also followed this practice where consulting print editions.

When quoting Old Icelandic and Latin I have followed as much as possible the orthography of the text at hand, although this may vary in different editions. In my own prose, I have anglicised spellings as in the translations I have used. 


\section{Contents}

Acknowledgements $\quad$ ii

Abbreviations

Referencing $\quad$ V

Note on the Translations vi

Orthographical Note vi

Contents vii

Introduction 1

Chapter One: Women, magic and the supernatural 8

$\begin{array}{ll}\text { Introduction } & 8\end{array}$

Magical Protection 9

$\begin{array}{ll}\text { Healing } & 13\end{array}$

$\begin{array}{ll}\text { Prophecy } & 17\end{array}$

$\begin{array}{ll}\text { Cursing } & 23\end{array}$

$\begin{array}{ll}\text { Spell-casting } & 28\end{array}$

Knowledge/teaching of magic 32

$\begin{array}{ll}\text { Magical corruption } & 33\end{array}$

Shape-changing 36

Interaction with the dead 38

$\begin{array}{ll}\text { Conclusion } & 40\end{array}$

Chapter Two: Women and sexual transgressions 42

Introduction $\quad 42$

Incest $\quad 42$

Mythology 43

Hrolf Kraki 44 
Volsungs $\quad 45$

History of the Danes $\quad 48$

Death and Desire $\quad 49$

Disloyalty to family due to romantic relationship $\quad 51$

Adultery $\quad 54$

Riddarasögur $\quad 56$

Trying to stop marital sex $\quad 58$

Making own marital decisions / leaving husband/lover $\quad 60$

$\begin{array}{ll}\text { Seduction } & 62\end{array}$

$\begin{array}{ll}\text { Fornication } & 66\end{array}$

$\begin{array}{ll}\text { Promiscuity } & 68\end{array}$

$\begin{array}{ll}\text { Wanton behaviour } & 71\end{array}$

$\begin{array}{ll}\text { Conclusion } & 75\end{array}$

Chapter Three: Women in the domain of men 77

$\begin{array}{ll}\text { Introduction } & 77\end{array}$

$\begin{array}{ll}\text { Maiden Warrior } & 77\end{array}$

History of the Danes $\quad 83$

$\begin{array}{ll}\text { Maiden King } & 87\end{array}$

$\begin{array}{ll}\text { Valkyrie } & 92\end{array}$

Magic in battle $\quad 99$

Men in the domain of women 100

$\begin{array}{ll}\text { Conclusion } & 103\end{array}$

$\begin{array}{ll}\text { Chapter Four: Murderous women } & 105\end{array}$

$\begin{array}{lr}\text { Introduction } & 105\end{array}$

Suicide and dying of heartbreak 105 
$\begin{array}{ll}\text { Suicide } & 105\end{array}$

$\begin{array}{ll}\text { Dying of heartbreak } & 110\end{array}$

$\begin{array}{ll}\text { Infanticide } & 112\end{array}$

$\begin{array}{ll}\text { Killing natal family } & 115\end{array}$

$\begin{array}{ll}\text { Killing step-kin } & 116\end{array}$

$\begin{array}{ll}\text { Killing of husband } & 118\end{array}$

Killing suitor/lover 122

Killing to gain a husband 123

$\begin{array}{ll}\text { Killing servants } & 124\end{array}$

Helping/inciting to kill 126

$\begin{array}{ll}\text { Post-death } & 130\end{array}$

Killing by supernatural females $\quad 130$

General death 132

Mythology 132

History of the Danes 133

$\begin{array}{ll}\text { Conclusion } & 134\end{array}$

$\begin{array}{ll}\text { Conclusion } & 135\end{array}$

Bibliography 141 


\section{$\underline{\text { Introduction }}$}

'Hefi ek par til unnit alla hluti, at Siggeirr konungr skyldi bana fá. Hefi ek ok svá mikit til unnit at fram kamisk hefndin, at mér er með engum kosti lift. Skal ek nú deyja með Siggeiri konungi lostig, er ek átta hann nauðig.'

(Völsunga Saga VIII) ${ }^{1}$

'To that end I have done all things, so that King Siggeir should go to his death. I have also granted so much to happen so that vengeance be brought about, that for me there is no choice of life. I shall now die with King Siggeir willingly, while I married him unwilling., 2

The last words of Signy Volsungsdottir are despairing in their triumph. Married without choice to the man who would be the bane of her father and brothers, Signy has to make a clear ranking of her loyalties, and she herself is at the bottom of this list. Out of obedience to her father Volsung she allows herself to be given as a 'peace-weaver', and even when she knows that ófriðr, or 'un-peace', is inevitable, she is compelled to stay with her husband. When her family is destroyed, her first priority is to avenge them, and she does all in her power to bring this about. She can only save one of her brothers, but by committing incest with Sigmund she ensures that the Volsung line can continue, untainted by Siggeir's inferior blood. ${ }^{3}$ Yet, despite Signy's decision to place her own kin at the top of her priorities, she does

\footnotetext{
${ }^{1}$ Byock, Jesse L. (trans.). The Saga of the Volsungs. London: Penguin, 1999. Guðni Jónsson and Bjarni Vilhjálmsson (eds), Fornaldarsögur Norðurlanda (Reykjavík: Bókaútgáfan Forni: 1943-4). Retrieved from Perseus Collection: Germanic Materials. URL http://www.perseus.tufts.edu/hopper/text.jsp?doc=Perseus:text:2003.02.0001

${ }^{2}$ Translation mine.

${ }^{3}$ Although Signy herself is not an ancestor of Sigurd the dragon-slayer, the slaying of her children by Siggeir and the birth (and survival) of Sinfjotli, her son by her brother, show that the line of the Volsungs is not lessened in any way, but if anything is strengthened (echoed by Sigemund's infamous lines ending the first act of Die Walküre: 'Braut und Schwester / bist du dem Bruder - / so blühe denn Wälsungen-Blut!'; 'Wife and sister / you'll be to your brother - / so let the Volsung-blood increase!' Richard Wagner, Die Walküre (Munich: National Theatre, 1870). Lyrics retrieved from Zeno.org Meine Bibliothek. URL http://www.zeno.org/Literatur/M/Wagner,+Richard/Musikdramen/Der+Ring+des+Nibelungen/Die+ Walk\%C3\%BCre/1.+Akt/3.+Szene).
} 
acknowledge an obligatory loyalty to her husband. She does not kill him herself in bed. She provides him with heirs, ${ }^{4}$ and although she brings about the end of his life, she does so also at the cost of her own. She completes her revenge by ensuring that her husband knows that he has no kin that will avenge him in turn. She has no desirable option in the choices before her, and in prioritising her loyalties in order to act with honour regarding her blood-kin, she must transgress in other areas, and bring shame upon herself. Signy is very aware that she has not acted towards her husband in an honourable way. She herself is greatly dishonoured by the deeds, which include incest and murder, that she has done in order to bring about his fall. To redeem herself as much as possible, in dying with her husband (thus atoning for her disloyalty to him, and ending the life which she believes she has sullied irremediably) she once more transgresses, in committing the act of suicide.

Signy is both a very complex and a highly intriguing character, and she is my 'hook' into this thesis topic. In researching an honours essay, I was amazed at just how little had been written about her. I expected her to be a major topic for discussion, not least because the episode of her revenge and death appears (in a censored form) in E.V. Gordon's An Introduction to Old Norse: ${ }^{5}$ however, this is not the case. Not only is there very limited critical material about her, but unlike many of the other characters in Volsungs, this appears to be her unique appearance in surviving medieval literature. Due to these limitations, I have broadened my research somewhat, so that while the core springs from Signy's motivations and transgressive actions, I have extended my field of interest to include other

\footnotetext{
${ }^{4}$ Notwithstanding that she orders them to be killed when they do not act to the standard required of Volsungs.

${ }^{5}$ E.V. Gordon, An Introduction to Old Norse, $2^{\text {nd }}$ Ed. rev. A.R. Taylor (Oxford: Clarendon, 1957).
} 
transgressing women in the fornaldarsögur, Saxo Grammaticus' Gesta Danorum Books I-IX, ${ }^{6}$ Snorri Sturluson's Heimskringla ${ }^{7}$ and Edda, ${ }^{8}$ and the Poetic Edda. ${ }^{9}$ These texts contain a great deal of cognate material.

Categorical groupings of texts are at times tenuous. The idea of fornaldarsögur as a genre was not coined until the early $19^{\text {th }}$ century by Carl Christian Rafn. The term means 'tales of ancient times', and they are also known as 'legendary sagas' and 'mythical-heroic sagas'. Rafn put Volsungs into this category, as well as most of the other sagas I have looked at. Generally, these are romances, stories of heroes on adventures and journeys, often involving a bridal-quest. They are mainly set abroad rather than in Iceland, and mostly in pagan times. ${ }^{10}$ As I have not been able to access translations for all of the fornaldarsögur, a small number are not considered in this thesis. ${ }^{11}$ I have considered a few riddarasögur, French chivalric stories translated into Icelandic, in order to compare the two romance styles.

\footnotetext{
${ }^{6}$ Saxo Grammaticus, The History of the Danes, vols 1 \& 2, trans. Peter Fisher, ed. Hilda Ellis Davidson (Cambridge: D.S. Brewer, 1979-80). Saxo Grammaticus, Saxonis Gesta Danorum, ed. J. Olrik and H. Raeder (Hauniae: Levin \& Munksgaard, 1931-).

${ }^{7}$ Snorri Sturluson, Heimskringla. Part Two: Sagas of the Norse Kings, trans. Samuel Laing (London: J.M. Dent, 1961). Snorri Sturluson, Heimskringla eða Sögur Noregs konunga, ed. N. Linder and H.A. Haggson (Uppsala: W. Schultz, 1869-72). Retrieved from Heimskringla. URL http://www.heimskringla.no/wiki/Heimskringla

${ }^{8}$ Snorri Sturluson, Edda, trans. Anthony Faulkes (London: Everyman, 1987). Snorri Sturluson, Edda Snorra Sturlusonar, ed. Guðni Jónsson (Akureyri, Iceland: Prentverk Odds Bjornssonar, 1954). Retrieved from Heimskringla. URL http://www.heimskringla.no/wiki/Edda_Snorra_Sturlusonar ${ }^{9}$ Carolyne Larrington (trans.), The Poetic Edda (New York: Oxford, 1996). Guðni Jónsson (ed.), Eddukvaði Samundar-Edda (Akureyri, Iceland: Islendingasagnautgafan, 1954). Retrieved from Heimskringla. URL http://www.heimskringla.no/wiki/Eddukvæði

${ }^{10}$ Torfi H. Tulinius, 'Sagas of Icelandic Prehistory', in Rory McTurk (ed.) A Companion to Old Norse-Icelandic Literature and Culture (Malden, Massachusetts: Blackwell Publishing, 2005) p. 447.

${ }^{11}$ These are Áns saga bogveigis, Hálfdanar saga Brönufóstra, Hjálmpes saga ok Ölvis, Sturlaugs saga starfsama, Sögubrot affornkonungum and Sörla saga sterka.
} 
I have also examined the Icelander Snorri Sturluson's Ynglinga Saga ${ }^{12}$ and Prose Edda, which are works that deal with the supernatural and the mythological, rather than history.

The earliest source I have looked at is eddaic poetry. This contains analogues to Snorri's mythology, and the heroic tales of the fornaldarsögur.

While Saxo's History was neither written in Iceland nor by an Icelander, like the fornaldarsögur it is looking back at Germanic tales of heroic times, drawing heavily on Icelandic sources. It contains a wealth of stories regarding women, many of whom are transgressive. Saxo's florid Latin style often provides a contrast to the brusque tone of the Icelanders, and he makes comments himself where Icelandic authors do not. 'History' is perhaps not the best description of the work, as it is full of the supernatural and unrealistic.

At times, passing reference is made to other areas of Old Icelandic and medieval literature, but due to the constraints of this thesis my focus will remain on the literature mentioned above, which has not been looked at for this purpose before. As such, this thesis will not take into account the role of women in the already well documented family sagas.

While Volsungs focuses on its main female characters nearly as much as its men, if not more, ${ }^{13}$ this is not the case in the other fornaldarsögur, which, rather than following a dynasty, generally follow a male hero, or pair of heroes, throughout a number of adventures. Nonetheless, a considerable number of transgressive and

\footnotetext{
${ }^{12}$ In Heimskringla.

${ }^{13}$ Grimstad suggests that rather than seeing the narrative as being shaped around the men, an alternative model could highlight the marriages of the three main women as the plot's structural framework. Kaaren Grimstad (ed.), Völsunga sage (Saarbrucken: AQ-Verlag, 2000), p. 22.
} 
strong-willed women are present, often as stock characters, but also as some more individualised depictions. The situation is similar in History. The mythological section of the Poetic Edda mainly focuses on the male asir, with the ásynjur generally background figures, but in the heroic section the women come far more to the forefront. Snorri's Prose Edda is based partly on the poems of the Poetic Edda, but even in the mythological section here the women seem to be more independent than in its source. Signy and the other women in Volsungs are not the sole representations in Scandinavian heroic and mythological literature of women who go beyond the bounds they are normally expected to act within. In the Icelandic texts, defining what these boundaries are is challenging, as very little judgement is provided by the narrators. This can be done to a certain extent by looking at the consequences various women experience, and the reactions expressed by other characters.

The term 'transgression' needs to be defined. To quote the Oxford English Dictionary, ${ }^{14}$ 'transgression' is:

1. a. The action of transgressing or passing beyond the bounds of legality or right; a violation of law, duty, or command; disobedience, trespass, sin. b. The action of passing over or beyond. (Only as the etymological sense of the word.)

I am using both of these senses: firstly, doing what is morally unacceptable or evil, whether in a Christian or pagan context, ${ }^{15}$ but also the etymological trans-gradi 'to

\footnotetext{
14 'transgression'. Oxford English Dictionary, (Oxford: Oxford University Press, 2009). URL http://dictionary.oed.com/cgi/entry/50256254?query_type=word\&queryword=transgression\&first=1 \&max_to_show $=10 \& \operatorname{single}=1 \&$ sort_type $=$ alpha

${ }^{15}$ Nearly all of the literature I am looking at is set in pagan times, but conversely it was all written down, and most of it composed, in a Christian setting. As such, both moral perspectives need to be considered.
} 
step over', as of a boundary, into what is not acceptable (or conventional) behaviour. This can be hard to judge, as the laconic tone of the narrative voice rarely expresses judgement. Generally, I have judged this as being women who act from their own initiative, and do not act passively in response to the men in their lives. I have seldom mentioned the pliant and obedient women of these stories, who do come up at least as much as these more outspoken representatives.

I have approached the thesis thematically, based loosely on Signy's own areas of transgression. It is not structured around 'types' of women (i.e. troll-wives and other supernatural beings are not separated from humans), as I do not find this helpful for gaining an overall perspective of the transgressive actions of women. ${ }^{16}$ Being a troll-wife, in this thesis, is not considered a transgression for its own sake, but because of the actions these trolls take.

Firstly, I will look at women's involvement in magic and the supernatural, which includes witchcraft, prophecy and shapeshifting. Secondly, I will look at various sexual transgressions, such as adultery, incest, fornication and promiscuity. In Chapter Three I discuss an area which does not involve Signy, but that comes up with moderate frequency elsewhere: that is, the denial of womanliness, such as acting as a warrior or king. Finally, Chapter Four discusses various sorts of homicide, including infanticide, suicide, and the murder of kin or spouse.

In sum, the aim of this thesis is to present a survey of the types of women that transgress in Old Icelandic mythological and heroic texts, their reasons for doing so, and the ways in which they do it. As I believe that this has not been looked

\footnotetext{
${ }^{16}$ A certain amount of research has already been done on specific types of women. See further in the notes to Ch. 1: Women, Magic and the Supernatural.
} 
at before, I hope this research will be of use to further study of the role of women in the fornaldarsögur. 


\section{Chapter One: Women, magic, and the supernatural}

\section{Introduction}

Magic and the supernatural are intrinsic aspects of Old Icelandic heroic and mythological literature. The fornaldarsögur are generally now considered a native form of the romance, ${ }^{17}$ and the uncanny and magical are significantly present in most forms of the romance of medieval Europe, as well as, of course, in the heroic and mythological literature of most societies. The important role women play in magic in Icelandic texts is not particularly surprising: they are the wicked stepmothers who later become a part of folktales and fairytales; the prophetesses sometimes in the background of the tales, decreeing the inevitable; and others teaching magic, cursing, and shapeshifting.

These women include troll-wives (both princesses under a curse and trollwives proper), witches, prophetesses and valkyries. I am, however, focusing on their actions rather than their natures: that is, I will be approaching this chapter by looking at different magical motifs that occur, and comparing women within each motif. A number of studies have already been done focusing specifically on troll-wives and valkyries. ${ }^{18}$ My aim is to present an overall picture of the way magic and women are incorporated into the fornaldarsögur, Icelandic mythology, and Saxo's History.

\footnotetext{
${ }^{17}$ Hermann Pálsson and Paul Edwards (trans.), Seven Viking Romances (London: Penguin, 1985), p.

7. Guðni Jónsson and Bjarni Vilhjálmsson (eds), Fornaldarsögur Norðurlanda (Reykjavík: Bókaútgáfan Forni: 1943-4). Retrieved from Perseus Collection: Germanic Materials. URL http://www.perseus.tufts.edu/hopper/text.jsp?doc=Perseus:text:2003.02.0017

${ }^{18}$ For valkyries, see: Charles Donahue, 'The Valkyries and the Irish War-Goddesses', Publications of the Modern Language Association 56.1 (1941) pp. 1-12; Jenny Jochens, Old Norse Images of Women (Philadelphia: University of Pennsylvania Press, 1996), pp. 38 and 95-6; A.H. Krappe, 'The Valkyries', The Modern Language Review 21.1 (1926), pp. 55-73; Olsen, Alexandra O, ‘The
} 
On the whole, these texts contain male-driven storylines. ${ }^{19}$ The magical function of women, therefore, usually relates to the primary story of the male protagonist(s). Sometimes they help the hero, and sometimes they hinder him and provide challenges on his adventures. Sometimes they act on behalf of the hero. In Volsungs, Signy, for example, does not engage in magic for her sake, but for her brother's, her dead father's, and for her paternal line in general. Her own needs and honour are secondary to those of her kinsmen. The stories do not normally follow these women with magical abilities from beginning to end, but bring them in where they are relevant to the central plot. The heroes encounter many troll-wives and giantesses on their journeys, and form relationships with them. Men consult witches, to find people or curse them, for example. Nonetheless, while the main storyline may not revolve around these women, they are often as memorable as the heroes.

\section{Magical protection}

A woman giving the hero magical protection comes up with considerable frequency, both in the fornaldarsögur and the contemporaneous riddarasögur. In the Ivan sagas, Iven/Ivan gets magical protection, in the form of a ring, from the two main

Valkyrie reflex in Havelock the Dane'. Essays on Old, Middle, Modern English and Old Icelandic ed. Loren C. Gruber (Lewiston: The Edwin Mellen Press, 2000) pp. 317-335.

For trollwives, see: Sandra Ballif, 'Nasty, Brutish, and Large: Cultural Differences and Otherness in the Figuration of the Trollwomen of the Fornaldar sogur', Scandinavian Studies, 73.2 (Summer 2001), pp. 105-24; Lorenzo Lozzi Gallo, 'The Giantess as Foster-Mother in Old Norse Literature', Scandinavian Studies 78.1 (Spring 2006), pp. 1-20; Lotte Motz, 'The divided image: a study of the giantesses and female trolls in Norse myth and literature', Mankind Quarterly, 27.4 (1987) pp. 463478.

${ }^{19}$ This is not an absolute of course, as some females, such as Freyja, are more important than their relatively obscure husbands (Od in Freyja's case). However, most of the fornaldarsögur are named for the male protagonist, except for Hervarar saga ok Heidreks. 
female characters. This has several variations: his beloved gives him a magical ring so that he cannot be captured or cut by weapon (Ívens Saga VIII, 66-7). ${ }^{20}$ When he forgets her she demands it back (Iven IX, 68-9). In the Old Swedish version of the story, she says that as long as he is thinking of her, no misfortune can come to him. In this version she also gives him a powerful golden ring which means he cannot be harmed while he remembers her (Harra Ivan 100-1). ${ }^{21}$ When the maid, Luneta, is hiding Ivan, she lends him a golden ring that gives the wearer invisibility (Haerra 48/49). Whereas magical rings come up in original Old Icelandic literature as well, most famously Andvari's ring of the Volsungs, these more often entail a curse than invisibility or protection. ${ }^{22}$ The motif of a ring having the power to protect seems to only occur in the translated French texts. Other jewellery can also bestow a form of magical protection. In Hálfdanar saga Eysteinssonar, ${ }^{23}$ the old woman with magical ability gives Halfdan a necklace which later protects him from Goldball, a monstrous female troll (Halfdan XVI-XVII, 188). ${ }^{24}$

However, the most common type of protection is the magical shirt, jacket or armour. $^{25}$ The best known magically protected character is probably Ragnar Lothbroka, or Ragnar Hairy-Britches. He has his nurse give him a woollen cloak and some shaggy thigh coverings, which protect him (History IX, [281] 252). In

\footnotetext{
${ }^{20}$ Marianne E. Kalinke (ed.), Norse Romance. Vol. 2: The Knights of the Round Table (Cambridge: D.S. Brewer, 1999).

${ }^{21}$ Marianne E. Kalinke (ed.). Norse Romance. Vol. 3: Harra Ivan (Cambridge, D.S. Brewer, 1999).

22 e.g. The curse that the ring of Andvari should be the deadly destruction of whoever possessed it. Skáldskaparmál XLVI, Prose Edda, p. 100.

${ }^{23}$ Hermann Pálsson and Paul Edwards (trans.) Seven Viking Romances. London: Penguin, 1985. Guðni Jónsson and Bjarni Vilhjálmsson (eds), Fornaldarsögur Norðurlanda (Reykjavík: Bókaútgáfan Forni: 1943-4). Retrieved from Perseus Collection: Germanic Materials. URL http://www.perseus.tufts.edu/hopper/text.jsp?doc=Perseus:text:2003.02.0017

${ }^{25}$ In History II, Davidson (p. 26, note 4) says that Grytha, the ancestor of the Danes in Book I, may be that Grid who helps Thor in Skaldskaparmal XVIII by lending him a girdle of might, gloves of iron and a magic staff. This would make magical protection an especially strong motif in History.
} 
Ragnarssona páttr the thigh coverings protect him from the snake in Thora's bower, enabling him to succeed in his bridal quest (Ragnarssons I) ${ }^{26}$ In Ragnars saga loðbrókar and Ragnarssons, Aslaug, Ragnar's wife (and daughter of Sigurd and Brynhild of Volsungs) gives her husband a protective jacket, and he is not killed until this is removed (Ragnarssons III, Ragnar $L \mathrm{XV}$ 237-9). ${ }^{27}$ The valkyrie Brynhild herself does not give anyone magical protection after she disobeys Odin's will, and because of protecting the wrong man is doomed to mortality and marriage. Yet, her rival, Gudrun, made wise by the dragon's heart which Sigurd fed her, prepares her sons magical drink and armour that no iron can bite (Volsungs [XLIV] XLII 108). However, as they disregard her advice on how to fight, they lose their lives all the same and her protection is no use.

In Örvar-Odds saga Olvor promises to makes Odd a protective shirt if he promises in return that he will leave her and her kinswomen alone, and his agreement shows that he values it highly. The shirt would stop him being hungry, cold, tired, burnt, or hurt by weapons, unless he should run away (Arrow-Odd XII 52). ${ }^{28}$ His friend and travel companion, Hjalmar, is not so lucky, because unlike the magically protected Odd, he does not survive the fight with Angantyr and his

\footnotetext{
${ }^{26}$ Peter Tunstall (trans.), The Tale of Ragnar's Sons. Retrieved from Northvegr Foundation. URL http://www.northvegr.org/lore/oldheathen/055.php Guðni Jónsson and Bjarni Vilhjálmsson (eds), Fornaldarsögur Norðurlanda (Reykjavík: Bókaútgáfan Forni: 1943-4). Retrieved from Perseus Collection: Germanic Materials. URL http://www.perseus.tufts.edu/hopper/text.jsp?doc=Perseus:text:2003.02.0034

${ }^{27}$ Margaret Schlauch (trans.), The Saga of the Volsungs; The Saga of Ragnar Lodbrok together with the Lay of Kraka (New York: AMS Press, 1978).

Guðni Jónsson and Bjarni Vilhjálmsson (eds), Fornaldarsögur Norðurlanda (Reykjavík: Bókaútgáfan Forni: 1943-4). Retrieved from Perseus Collection: Germanic Materials. URL http://www.perseus.tufts.edu/hopper/text.jsp?doc=Perseus:text:2003.02.0029

${ }^{28}$ Hermann Pálsson and Paul Edwards (trans.) Seven Viking Romances. London: Penguin, 1985. Guðni Jónsson and Bjarni Vilhjálmsson (eds), Fornaldarsögur Norðurlanda (Reykjavík: Bókaútgáfan Forni: 1943-4). Retrieved from Perseus Collection: Germanic Materials. URL http://www.perseus.tufts.edu/hopper/text.jsp?doc=Perseus:text:2003.02.0028
} 
brothers (Arrow-Odd XIV 68). When Odd returns to tell Hjalmar's beloved, Ingibjorg, of his death, she is sewing Hjalmar a shirt. This echoes Olvor making Odd's shirt, and highlights the different fates of the two men. Whether he appreciates it or not, luck is on Odd's side. He is invincible until his life has run its course, as according to prophecy he cannot die until he returns to his birthplace, Berurjod, aged three hundred (Arrow-Odd II 30). ${ }^{29}$

Discarding protection is a sure way to be injured or to lose life. In Hrómundar saga Gripssonar, Hromund discards the protective shield made for him by Svanhvit because he is teased about the ribbon on it, and he is subsequently injured (Hromund VI-VII 9-10). ${ }^{30}$ On one occasion magical protection is actually intended to cause death. When Ulvild gives her brother Frothi a coat impenetrable to steel, he suffocates under it (History II [50] 46). As she had spent some time devising how to kill him, this consequence of what would usually be seen as a benevolent action is not as surprising as it might be. A final example of protective clothing is in History, when three nymphs give Hother a belt that would guarantee his victory against Balder (History III [75] 69). ${ }^{31}$ While Balder's death fighting against Hother bears little resemblance to Hod killing Baldr with mistletoe (Gylfaginning XLIX, Prose Edda 48), supernatural intervention is involved in both: Baldr's 'Achilles Heel' is his vulnerability to mistletoe, abused by Loki, and his

\footnotetext{
${ }^{29}$ See Ch. 1: Prophecy.

${ }^{30}$ W. Bryant Bachman, Jr and Guðmundur Erlingsson (trans), Six Old Icelandic Sagas (Lanham, Maryland: University Press of America, 1993). Guðni Jónsson and Bjarni Vilhjálmsson (eds), Fornaldarsögur Norðurlanda (Reykjavík: Bókaútgáfan Forni: 1943-4). Retrieved from Perseus Collection: Germanic Materials. URL

http://www.perseus.tufts.edu/hopper/text.jsp?doc=Perseus:text:2003.02.0024

${ }^{31}$ One of the nymphs also wants him to eat from their banquet, although another stops her by saying it would not only deprive Balder but would strengthen his enemy. There is a lacuna in the text, so there may have been further details about the banquet and belt.
} 
protection from everything else is not enough. Hother would probably not have been able to kill Balder without the intervention of the nymphs and the magical belt.

Magical protection is not always in the form of clothing. Again reminiscent of Achilles, Soti, in Göngu-Hrólfs saga, has a bath prepared for him by his sorceress foster-mother which makes him invulnerable to weapons (Gongu-Hrolf XVII 65). ${ }^{32}$ He is described as a berserker and a troll. Hrolf kills him by striking him in the head, which must not have gone under the bathwater (XVIII 67).

In History Kraka tells her son and stepson that all they need to do in order for her to protect them is to say her name. She says she holds a divine power, as she is an associate of the gods (History V [125] 111). When Erik is attacked, he says her name, and his shield drops down from the rafters in front of him and saves his life (V [140] 125). This is similar to the protection that might be expected from a valkyrie, although Kraka is not there in person (compare Sigmund's death in The Saga of the Volsungs, where a spaewoman shields him until Odin comes and strikes him (Volsungs XI 53)).

\section{Healing}

In medieval literature, healing has more to do with knowledge of magic and herb lore than science. While on occasion a man may heal, such as Mondul the Dwarf (Gongu-Hrolf XXV 84), healing is predominantly the domain of women: young, old,

\footnotetext{
${ }^{32}$ Hermann Pálsson and Paul Edwards (trans.), Göngu-Hrólfs Saga (Toronto: University of Toronto Press, 1980). Guðni Jónsson and Bjarni Vilhjálmsson (eds), Fornaldarsögur Norðurlanda (Reykjavík: Bókaútgáfan Forni: 1943-4). Retrieved from Perseus Collection: Germanic Materials. URL http://www.perseus.tufts.edu/hopper/text.jsp?doc=Perseus:text:2003.02.0014
} 
and not always human. Healing is primarily needed to counter battle wounds, but also can cure curses and madness, as demonstrated below.

One distinctive feature of healing in the fornaldarsögur is the ability to reattach severed limbs. In Gongu-Hrolf, Ingigerd preserves Hrolf's chopped off feet with special herbs, and later reattaches them (Gongu-Hrolf XXIV 82). Similarly, in Egils saga einhenda ok Ásmundar berserkjabana, the trollwoman Eaglebeak preserved Egil's hand from when he lost it defending her, and when they met years later she is able to reattach it (Egil and Asmund XIV 249). ${ }^{33}$ These are two contrasting female characters, whose lives have few other parallels. Ingigerd is never transformed into a troll, and Eaglebeak is never the object of the bridal quest. This shows healing can be a skill explored by a range of females.

Herb-lore is a rare ability, both in the fornaldarsögur and the riddarasögur. In Tristrams saga ok Ísöndar only the Queen of Ireland, his enemy, is able to heal Tristram's wounds, and only Ísodd has the ability in Tristrams kvæði (Tristram ok Isondar XXVIII 80-1, Tristrams kvaedi 230-3). ${ }^{34}$ Similarly, in Hromund, Svanhvit has to send Hromund to a particular old man and woman in the woods who understand magic so that he can be healed, as her own healing abilities are not extensive (Hromund VIII 11). The fact that they live in the woods suggests that their magical activities would not be generally approved of. The magical protection they give him continues beyond his healing, and into his future adventures.

\footnotetext{
${ }^{33}$ Hermann Pálsson and Paul Edwards (trans.) Seven Viking Romances. London: Penguin, 1985. Guðni Jónsson and Bjarni Vilhjálmsson (eds), Fornaldarsögur Norðurlanda (Reykjavík: Bókaútgáfan Forni: 1943-4). Retrieved from Perseus Collection: Germanic Materials. URL http://www.perseus.tufts.edu/hopper/text.jsp?doc=Perseus:text:2003.02.0010

${ }^{34}$ Marianne E. Kalinke (ed.). Norse Romance. Vol. 1: The Tristan Legend. Cambridge: D.S. Brewer, 1999.
} 
A motif that recurs with variations is healing needed because a woman unable to give birth. In Volsungs, Volsung's mother is unable to give birth for over six years, and when she realises she is going to die she has Volsung cut out of her (Volsungs II 37). He survives, but she does not. In at least two other situations special attention is needed for a birth to happen. In Oddrúnarkviða, Borgny is unable to give birth until Oddrun comes and sings. Presumably this indicates some special magical ability on Oddrun's part, as 'powerfully Oddrun sang, / bitter spells for Borgny’ (Oddrun VII, Poetic Edda 206). ${ }^{35}$ In Sigrdrífumál, magical assistance for childbirth is also acknowledged necessary by Sigrdrifa, as she tells Sigurd 'Helpingrunes you must know if you want to assist / and release children from women' (Sigrdrifumal IX, Poetic Edda 168), ${ }^{36}$ but there is only one occurrence of a man helping with childbirth in these texts. In Gongu-Hrolf an elf woman lures the hero to her cave, as her daughter is cursed and unable to give birth until human hands have touched her (Gongu-Hrolf XV 58). In this case it is the elf woman's knowledge of the curse, and her ability to attract help magically, rather than any particular healing property on her part or Hrolf's that enables her daughter to give birth.

In History Regnhild chooses her husband by examining his legs (I [30] 30). Unlike Skadi, who also has to choose her husband by his feet (Skaldskaparmal III, Prose Edda 61), her judgement is accurate. She had healed Hading when he was injured, and left her ring in his wound so that she would later be able to identify him. Her healing may not have been particularly magical, but her foresight enables her to marry the man she desires, who saved her from a giant. Although she has her

\footnotetext{
35 'Rammt gól Oddrún, / bitra galdra / at Borgnýju'.

36 'Bjargrúnar skaltu kunna, / ef pú bjarga vilt / ok leysa kind frá konum'.
} 
father's permission to marry whom she wishes, finding the concealed ring would be a sure way of getting the right man.

Madness is more a motif of the translated than the indigenous romances. Icelandic heroes are generally men of action, and their emotional and psychological states are seldom touched upon. In the riddarasögur, however, Ivan suffers madness, due to his troubles in love. He is healed by women, in both the Scandinavian versions of the story (Haerra 11. 2349-2484 114-121 and Ivens IX 68-9). The lady who finds him mad instructs her maid to rub his head with an ointment given to her by Morgan the Wise, which would drive the insanity from a man's mind. Instead, she rubs him all over. In Haerra she throws away the empty jar to conceal this. Her lady is angry with her because the ointment was very precious (Haerra 11.2450-2474, 120-121). It is not stated whether the extra ointment made a difference for Ivan; he makes a full recovery in both versions and the incident is not referred to again.

Troll-wives who are actually princesses under a curse often heal heroes, usually in order to break the curse. Heroes are sometimes saved by trolls who are enchanted princesses and need various favours from the heroes to break the enchantment; they then usually marry. This is the case in Grims saga loðinkinna, where Lofthaena, in the form of a troll, cannot become human again until some human man lets her rescue him, kisses her and sleeps in the same bed with her (Grim Shaggy-Cheek II). ${ }^{37}$ Similarly, in Porsteins saga Víkingssonar, Thorstein is rescued by Skellinefja, the princess Ingeborg under a curse, who requires him to agree to

\footnotetext{
${ }^{37}$ Peter Tunstall (trans.), The Saga of Grim Shaggy-Cheek. Retrieved from Northvegr Foundation. URL http://www.northvegr.org/lore/oldheathen/049.php

Guðni Jónsson and Bjarni Vilhjálmsson (eds), Fornaldarsögur Norðurlanda (Reykjavík: Bókaútgáfan Forni: 1943-4). Retrieved from Perseus Collection: Germanic Materials. URL http://www.perseus.tufts.edu/hopper/text.jsp?doc=Perseus:text:2003.02.0015
} 
marry her before she will heal him (Thorstein Vikingsson XIX 50). ${ }^{38}$ The Saga of Illuga saga Gríðarfóstra has a variation: Illugi is not himself dying, but the men he is with think they will die of cold, so he is sent to fetch fire. He comes to the cave of the troll-wife Grid, who is the cursed princess Signy. He has to tell her three true things in order to get the fire. She then sends him to bed with her beautiful daughter, but three times pulls him up and threatens him with her knife. Because he is not afraid, the curse is broken (Illugi IV-V 68-71) ${ }^{39}$ He goes back to his men with the fire, and later marries the daughter. These saving acts of healing are required so that the women can be freed of their curses, but, nevertheless, the healing is effective.

\section{Prophecy $^{40}$}

Prophecy is commonplace throughout the fornaldarsögur and the Eddas. It has divine associations; Frigg and Odin have powers of prophecy (Prologue IV, Prose Edda 3). With the notable exceptions of Odin and Sigurd's uncle Gripir (see Volsungs XVI 60, Grípisspá in Poetic Edda 143-150), it is generally the domain of women. Prophecy seems to be a mixture of threat and prediction, and it always comes to pass. Sometimes prophecy comes from a divine decree, and on other occasions is due to the whim of the prophetess. It is sometimes interlinked with dream interpretation. Dream interpretation is not necessarily the work of somebody

\footnotetext{
${ }^{38}$ Rasmus B. Anderson and Jón Bjarnason (trans.), Viking Tales of the North (Chicago: S.C. Griggs and Co., 1877). Guðni Jónsson and Bjarni Vilhjálmsson (eds), Fornaldarsögur Norðurlanda (Reykjavík: Bókaútgáfan Forni: 1943-4). Retrieved from Perseus Collection: Germanic Materials. URL http://www.perseus.tufts.edu/hopper/text.jsp?doc=Perseus:text:2003.02.0036

${ }^{39}$ W. Bryant Bachman, Jr and Guðmundur Erlingsson (trans), Six Old Icelandic Sagas (Lanham, Maryland: University Press of America, 1993). Guðni Jónsson and Bjarni Vilhjálmsson (eds), Fornaldarsögur Norðurlanda (Reykjavík: Bókaútgáfan Forni: 1943-4). Retrieved from Perseus Collection: Germanic Materials. URL http://www.perseus.tufts.edu/hopper/text.jsp?doc=Perseus:text:2003.02.0025

${ }^{40}$ See also Jochens pp. 113-131.
} 
designated as 'magical', but is often performed by queens. Professional soothsayers could also be employed to interpret dreams, as happens for Hading in Book One of History: the soothsayer interprets his dream by explaining that the animals in it represented his son and daughter (I [34] 33). ${ }^{41}$ Dream interpretation by women, unless deliberately falsified, is always accurate. Their male counterparts, such as Gunnar and Hogni in Volsungs ([XXXVI-XXXVII] XXXIV-XXXV 98-9), are less likely to interpret matters correctly.

Larrington says in her introduction to the Poetic Edda that the norns are figures of fate, who may be present at a child's birth, prophesying. Sometimes they are blamed when things go badly for humans. ${ }^{42}$ The Prose Edda gives their names as Weird, Verdandi and Skuld, and says they live by the ash-tree and shape men's lives (Gylfaginning XV, Prose Edda 18). They are always grouped as a trio. The prophecy most similar to the fairytale motif of two blessings and one curse is in Norna-Gests páttr. The three norns are travelling around the country together. When they come to the home of Gest's family, the first two norns prophesy good characteristics for the baby. The third norn, however, is annoyed by her treatment, and she says that Gest will only live as long as it takes for the candle to burn down. The other norns blow out the candle and give it to Gest's mother for safe keeping. When Gest has had enough of life, he relights the candle and dies when it is consumed (Norna-Gest XI-XII 186-8). ${ }^{43}$ The expectations of this curse are cleverly

\footnotetext{
${ }^{41}$ Soothsayer: 'augurio'.

${ }^{42}$ Larrington p. xii.

${ }^{43}$ George K. Anderson (trans.), The Saga of the Volsungs, together with excerpts from the Nornageststhattr and three chapters from the Prose Edda (Newark: University of Delaware Press,
} 
upset: rather than an early death, it indirectly gives the option of immortality, which Gest does not take. In History, Fridlef consults three oracles about his son. The first two give him good characteristics, but the third, 'a woman of rather petulant and jealous disposition', gives him meanness (History VI [169] 150). ${ }^{44}$ However, this quality is not very apparent in the following story. In Volsungs the norns set Helgi's fate to be the most famous of kings (VIII 47).

Women can often predict a great deal regarding their marriage. In Volsungs, Signy knows, through foresight and her family fetch, that her marriage to Siggeir will cause great misery (Volsungs IV 39). Yet, while her father does not deny what she says, he tells her it would be dishonourable for them not to keep their promises. Aslaug, her brother's granddaughter, predicts two things on her marriage bed: on the first occasion, she says that if she and her husband consummate their marriage before the time she deems appropriate, their son will be born without bones (Ragnarssaga VI 206); and on the second occasion, says that snakes in the eyes of her unborn son will prove that she is the daughter of Sigurd and Brynhild (Ragnarssaga IX 214). Her predictions are accurate: her children are known as Ivar the Boneless and Sigurd Snake-in-the-Eye. Whereas she did not want to consummate their marriage because of what she knew would happen to Ivar, it seems that she herself was responsible for the snakes in Sigurd's eyes, and not merely the bearer of tidings. In a similar vein in History, on their wedding night, Thyra asks Gorm that they remain abstinent for three nights, as she wants a dream

1982). Guðni Jónsson and Bjarni Vilhjálmsson (eds), Fornaldarsögur Norðurlanda (Reykjavík: Bókaútgáfan Forni: 1943-4). Retrieved from Perseus Collection: Germanic Materials. URL http://www.perseus.tufts.edu/hopper/text.jsp?doc=Perseus:text:2003.02.0027

44 'Protervioris ingenii invidentiorisque studii femina'. meanness: 'parsimoniæ crimen'. 
omen that their marriage would be fruitful. He agrees, and puts a sword between them in the bed. However, he has a dream that clearly indicates progeny, so that she does not even require him to abstain for one night (History IX [295-6] 266-7). This is not magical as in Aslaug's story, but still indicates great faith in dreams and prophecy.

Prophecy and dream interpretation comes up frequently in Volsungs and its cognates. Almost all the women engage in it to some extent. Brynhild is renowned for her wisdom, and although she tells Sigurd she can see little of his future life, she her saying 'it would be better if the hate of your in-laws did not descend upon you', may indicate that she does know more than she says (Volsungs [XXII] XXI 71). ${ }^{45}$ She also tells him that they are not fated to be together, which goes against appearances at this stage (Volsungs [XXV] XXIV 75), yet she also says 'it is unknown what fortune men will have to their dying day' ([XXV] XXIV 74). ${ }^{46}$ Although she downplays her prophetic powers, she accurately predicts the future on several occasions. For instance, Gudrun dreams of Sigurd, and her maid interprets her dream by saying that she will marry a king's son and love him much (XXVI 76). Gudrun goes to visit Brynhild, as she wants her to interpret her dream as well. Although Brynhild first tells her not to worry about it, when pressed, she tells Gudrun all that will come to pass, with the deaths of Sigurd, her brothers and Atli ([XXVII] XXVI 77). Gudrun is grieved by this, and yet does nothing to stop it. On her deathbed, Brynhild prophesies the future in great detail, specifically saying that Atli will outlive the Gjukings and be mightier ([XXXII] XXXI 92). Whether this

\footnotetext{
45 'Eigi skyldi mága hatr á pik koma'.

46 'Háttung er í, hverja giftu menn bera til síns endadags'.
} 
could be a curse, rather than a prophecy, is not clear. Brynhild certainly speaks from a powerful position: she has caused a serious violation by compelling men to break bonds of blood brotherhood, and surely by the power of her own spilt blood she would also be able to call down a heavy curse if she so desired.

Gudrun also plays her part, telling her brothers that when they ride to battle they will realise Sigurd was their luck and their strength ([XXXII] XXX 91). It may not require any prophetic powers to foresee this, but certainly in their next battle they are annihilated. In Guðrúnarkviða in forna in the Poetic Edda, she has a premonition of the death of her brothers, and the revenge she will exact (Gudrun II XXXI Poetic Edda 200). In the same poem, Atli has a dream that Gudrun will run him through, but she deliberately misinterprets this in order to appease him (XXXVII-XXXXIV 201-2, also in Volsungs [XXXV] XXXIII 96).

In both Volsungs and Atlamál in graenlenzku, Kostbera, Helgi’s wife, and Glaumvor, Gunnar's wife, have premonitious dreams about their husbands going to visit Atli, and warn them not to go (Volsungs [XXXVI-XXXVII] XXXIV-XXXV 98-9, Atlamal X-XXVIII Poetic Edda 219-221). Kostbera is worried about the confused runes from Gudrun, and tells her husband they warn of death (Volsungs [XXXV] XXXIV 98). The wives are, of course, ignored. Premonitory dreams tell of the future, and almost always come to pass, but as they are rarely believed they have little effect, other than misery for the dreamers. Usually the men are too set on the course they have already determined upon, and will not be deterred.

Prophecies can seldom be avoided. Arrow-Odd is furious when the prophetess Heid predicts his future, against his will (Arrow-Odd II 29-30). 
Nonetheless, it comes to pass, despite his elaborate attempts of avoidance. He kills his horse so that it may not kill him, as prophesied, and leaves the island where he lives (Arrow-Odd III 30-31). Many years later he returns and is killed by a snake in the skull of his horse (Arrow-Odd XXXI 121). The prophecy, however, meant that in all his travels and battles he was not able to be killed, as his doom lay at Berurjod, and he lived for the predicted three hundred years. In Bósa saga ok Herrauðs, the priestess Kolfrosta predicts that she will die within a month, and so steals a princess to be trained as her replacement (Bosi and Herraud VIII 211). ${ }^{47}$ It is this kidnapping that leads to her death at the hands of the heroes who come to rescue the princess. In Ásmundar saga kappabana the Duke's sister dreams about the coming of Asmund (Asmund VI 93), ${ }^{48}$ and in Hrólfs saga Gautrekssonar Queen Ingigerd predicts on two occasions, due to her dreams, that Hrolf and his companions will come, and she guesses their purpose is courtship (Hrolf Gautreksson VII 43-5, XII 60-1). ${ }^{49}$

Prophecy is employed as a literary device to foreshadow coming events. Prophetic statements and dream interpretation by women are always accurate, and avoidance of the predicted fate is impossible. Although Signy, Brynhild and Gudrun could see into their future, they were powerless to prevent it. No matter what lengths people go to to try to avoid their predicted future, it will always catch up with them

\footnotetext{
${ }^{47}$ Hermann Pálsson and Paul Edwards (trans.) Seven Viking Romances. London: Penguin, 1985. Guðni Jónsson and Bjarni Vilhjálmsson (eds), Fornaldarsögur Norðurlanda (Reykjavík: Bókaútgáfan Forni: 1943-4). Retrieved from Perseus Collection: Germanic Materials. URL http://www.perseus.tufts.edu/hopper/text.jsp?doc=Perseus:text:2003.02.0009

${ }^{48}$ W. Bryant Bachman, Jr and Guðmundur Erlingsson (trans), Six Old Icelandic Sagas (Lanham, Maryland: University Press of America, 1993). Guðni Jónsson and Bjarni Vilhjálmsson (eds), Fornaldarsögur Norðurlanda (Reykjavík: Bókaútgáfan Forni: 1943-4). Retrieved from Perseus Collection: Germanic Materials. URL http://www.perseus.tufts.edu/hopper/text.jsp?doc=Perseus:text:2003.02.0008

${ }^{49}$ Hermann Pálsson and Paul Edwards (trans.), Hrolf Gautreksson, a Viking Romance (Toronto: University of Toronto Press, 1972). Guðni Jónsson and Bjarni Vilhjálmsson (eds), Fornaldarsögur Norðurlanda (Reykjavík: Bókaútgáfan Forni: 1943-4). Retrieved from Perseus Collection: Germanic Materials. URL http://www.perseus.tufts.edu/hopper/text.jsp?doc=Perseus:text:2003.02.0022
} 
in the end. The prophetesses merely see the future, but some of them appear to cross into the related area of cursing.

\section{Cursing}

Cursing is an area which is obviously transgressive, in the sense of being 'wicked' as well as 'different'. It is done both to help and to hinder the heroes, and also affects other people in the sagas. Ordinary women, as well as troll-wives and witches, are able to perform curses, often in retaliation. Sometimes people try to withdraw their curses, but that is never allowed.

Cursing is not limited to native Icelandic romances. It comes up in the riddarasögur such as in Tristram ok Isondar, and where Queen Isodd curses Morhold's slayer and England (Tristram ok Isondar XXIX 84-85), and in Parcevals saga, where a woman wishes that a troll would carry Parceval off (Parceval II 112$113),{ }^{50}$ and when the ugly, fiend-like woman curses anyone who would greet Parceval, as he had not healed the Fisher-King (Parceval XIV 166/167). However, these are empty words, and do not directly cause anything to happen. ${ }^{51}$ Rather, they are an expression of emotion. In the fornaldarsögur, on the other hand, curses are more likely to have an effect. The giantesses Fenia and Menia, when not granted rest from the mill, grind out an army against Frodi (Gróttasöngr, Poetic Edda 260-3). Their feelings of bad will towards Frodi are expressed in a very literal curse, whereby what they say directly comes to pass.

\footnotetext{
${ }^{50}$ Marianne E. Kalinke (ed.), Norse Romance. Vol. 2: The Knights of the Round Table (Cambridge: D.S. Brewer, 1999).

${ }^{51}$ Although Tristram's life does seem a cursed one.
} 
The Volsung story is full of accomplished cursers. Gudrun curses the Gjukis for killing Sigurd, and Brynhild curses the woman who gets Gudrun to speak (Guðrúnarkviða in forna XXI, XXIII, Poetic Edda 180). Gudrun later curses Atli by his oaths to Gunnar (Atlakviða XXX, Poetic Edda 214). Oddrun, sister of Atli and Brynhild, curses Atli’s mother after she has killed Gunnar, Oddrun's lover (Oddrun XXXII, Poetic Edda 209). These are nearly all curses against immediate kin. Gudrun's curses are the only ones which have a direct impact on the plot, perhaps because she has enhanced abilities due to having eaten some of Fafnir's heart (Volsungs [XXVIII] XXVI 79). Kraka (Aslaug), daughter of Brynhild and Sigurd, carries on the tradition when she curses her fosterparents that every day may be worse than the one before (Ragnar L VI 205). Again, we are not shown whether this comes to pass.

Stories of troll-women often revolve around cursing, and they can be both active and passive participants. A troll-woman comes into play in one version of the story of Helgi and Svava. In Helgakviða Hjörvarðssonar, when Helgi's brother Hedin will not accept the company of a troll-woman, she curses him so that he vows to have Svava, which leads ultimately to the death of Helgi. Helgi, however, thinks this troll is his fetch, and that he is destined to die (Helgi Hi XXXII-XXXV, Poetic Edda 129-30).

The Saga of Ali Flekk is the most notable for trolls and cursing, as the point of the saga seems to be to recount the adventures the hero Ali has because of a series of curses between him and a family of trolls. That Ali himself is also able to perform powerful curses seems to be an anomaly, as otherwise he shows no magical ability 
or effeminacy. Ali is rude to the troll-wife Bluetooth, who curses Ali to marry her sister (Ali Flekk IV 45). ${ }^{52}$ He curses her to be a stone slab in the fireplace that would crack in two when he became free (Ali Flekk IV 45). Later, Bluetooth's brother curses Ali to become a wolf in the forest slaying livestock, particularly his own family's, until a woman begged for his release. Ali returns a curse that he must stay where he is, yelling and not getting rest, and that he should be hanged if Ali should get free (Ali Flekk VIII 50). Following this, Nott, his intended troll-spouse, comes to Ali in a dream, cursing him with wounds that would bring about his death after ten years and could only be healed by her brother who lived in distant lands (Ali Flekk XII 53). This is the first curse Ali is unable to reply to, perhaps due to his lack of control over his dream. Luckily, he is eventually healed by the brother, due to his wife's cunning (Ali Flekk XV 56). The brother curses them when they kill him, so that they must find Nott's daughter (Ali Flekk XVI 57). After they have found her, there are no more encounters with trolls, and the series of curses and the story are both at an end. This story is unusual in that so many men perform curses. However, all the curses performed by Ali and the trolls in reaction to Bluetooth's first curse and Ali's escape from Nott.

Stepmothers are frequent cursers. In Hrólfs saga kraka, the elfin woman is made unattractive by her stepmother's curse, and this is only remedied when Helgi lets her join him in bed (Hrolf Kraki [XI] XV 22) ${ }^{53}$ This motif comes up a lot. ${ }^{54}$ In

\footnotetext{
${ }^{52}$ W. Bryant Bachman, Jr and Guðmundur Erlingsson (trans), Six Old Icelandic Sagas (Lanham, Maryland: University Press of America, 1993). For The Saga of Ali Flekk in Old Icelandic see: Agnete Loth, Fornaldarsagas and late medieval romances : AM 586 4to and AM 589 a-f 4 to (Copenhagen: Rosenkilde and Bagger, 1977). I have been unable to interloan this.

${ }^{53}$ Jesse Byock (trans.), The Saga of King Hrolf Kraki (London: Penguin, 1998). Guðni Jónsson and Bjarni Vilhjálmsson (eds), Fornaldarsögur Norðurlanda (Reykjavík: Bókaútgáfan Forni: 1943-4).
} 
Illugi, Grimhild curses her stepdaughter Signy, so that she becomes a troll, and can only be saved by a man who is not afraid of the knife she brandishes when he is in bed with her daughter (Illugi IV-V 68-70). In Grim Shaggy-Cheek, Grimhild turns her stepdaughter Lofthaena into a troll, and she can only be rescued by having a human lover (Grim Shaggy-Cheek II). Similar to this is the story in Thorstein Vikingsson, where Ogautan curses Ingebjorg into being a troll, by swapping forms with his sister Skellinefja, until she might find a noble lover (Thorstein Vikingsson XVII 47). The major difference here, of course, is that Ogautan is a man, but he is effeminate in his cursing and general behaviour, very different to the hero Thorstein. Another example of a stepmother's curse is Hvit's in Hrolf Kraki. When her stepson, Bjorn, rejects her advances, she turns him into a bear (Hrolf Kraki [XIX] XXVI 37). She later ensures that his sons are affected by her curse as well, as she forces Bjorn's lover Bera to eat some of the bear-meat while she is pregnant, although Bjorn had specifically warned her not to do so (Hrolf Kraki [XX] XXVII 38-9). Their children, as a result, all have animal-like characteristics and great strength, but are outsiders ([XX] XXVII 40).

There are many other miscellaneous curses, mostly against close kin. In Helgakviða Hundingsbana, Svava curses her brother after he has killed Helgi (Helgi II XXXI-XXXIII 138). In Gongu-Hrolf, the elfwoman's daughter is cursed, and unable to give birth until human hands touch her (Gongu-Hrolf XV 58). ${ }^{55}$ In Hervarar saga ok Heiðreks, Hervor curses her father Angantyr if he is hiding his

Retrieved from Perseus Collection: Germanic Materials. URL

http://www.perseus.tufts.edu/hopper/text.jsp?doc=Perseus:text:2003.02.0023

${ }^{54}$ See further in Ch. 1: Healing.

${ }^{55}$ See Ch. 1: Healing. 
sword from her, and this makes him hand it over (Heidrek III 15). ${ }^{56}$ Busla threatens the king in Bosi and Herraud's Saga with a powerful curse, unless he should forgive the two heroes. The author calls attention to the fact it is not all recorded, for fear it should be repeated. The king gives in because of the curse (Bosi and Herraud V 205-8). In Halfdan Eysteinsson, Grim, who is Ingigerd in disguise, curses Halfdan, her future husband, that he must seek out her hand and ring (Halfdan VIII 179). This means that he is obsessed with finding her, although he does not know who she is. Cursing happens in History as well: in Book One, after Hading kills a monster at sea, a woman curses him, saying the gods and nature will be against him for slaying a benign deity (History I [29-30] 29).

A curse can sometimes have beneficial consequences. Had Lofthaena and Ingeborg not been turned into trolls, the heroes in each of the sagas might have died without their healing abilities. The 'trolls' are also able to take revenge on their cursers in ways that they never could if they were still princesses, under the domain of their fathers and social customs. The curse enables them to transgress their usual boundaries, and while they are constrained by the curses, they are loosened in other ways. Signy in Illugi never quite loses her troll-like characteristics, but immediately reverts to murder when her daughter's character is questioned (Illugi VI 71).

Being cursed also enables the 'good' characters to react with a more threatening curse. When Ingeborg is turned into a troll in Thorstein Vikingsson, she curses Ogautan so that he may have only a short time with his kingdom, and not enjoy it (Thorstein Vikingsson XVII 47). When Signy is cursed by Grimhild in

\footnotetext{
${ }^{56}$ Christopher Tolkien (ed. and trans.), The Saga of King Heidrek the Wise (London: Nelson and Sons, 1960). The translation and edition are on facing pages.
} 
Illugi, her daughter Hild returns a curse while Signy weeps: she decrees that Grimhild should stand one foot in the house, one in the king's hall, and slaves should build a fire between her legs, which she would drop into at the end of the curse. Grimhild is obviously horrified at this prospect, but when she tries to retract her curse, Hild will not let her (Illugi V 70). In Ali Flekk, Bluetooth also tries to take back her words when Ali retaliates, but to no avail (Ali Flekk IV 45). Being cursed enables the victim to respond in kind and make the curser regret their actions. The victim is often vengeful, and even when there is a chance to have the curse retracted they turn it down. This indicates that they care less about their own state than getting revenge.

\section{Spell-casting}

Spell-casting, and deliberately performing magic, is testament to the power of words and runes in Icelandic literature. Spell-casting is usually performed by 'magical' people, such as witches, whereas curses can also be performed by innocent victims. As shown in the curses above, words make things real and dangerous, and the tradition of flyting extends into the realm of magic in the form of verse-exchanging and chanting spells.

In some ways, magic is a fairly standard part of life in the fornaldarsögur, and is often treated in a matter-of-fact manner. All the same, the accusation of witchcraft is a dangerous one. Roller tries to protect his mother from such an accusation (History V [124] 110), and Bikki succeeds in having Svanhild killed by saying that the reason the horses will not trample her is not because she is beautiful, 
but because she is terrifying them with spells: hence the king agrees to hide her face (in Volsungs in a sack [XLII] XL 107; in History, face down VIII [257] 234). In Bosi and Herraud, the king threatens to torture Busla for being a witch (Bosi and Herraud V 207). Another hint of a possible punishment can be seen in Grim Shaggy-Cheek, as Grimhild, who is a troll-wife and had turned Lofthaena into a troll, is punished by having her head put in a sack and being stoned to death (Grim Shaggy-Cheek III). Witchcraft can be a serious matter.

Verse exchanging happens predominantly between one supernatural being and one human. Curses and spells are often recited in verse, and on some occasions the two parties vie for power. Verse exchanging is a battle of wills, like flyting, but unlike flyting can have a direct impact. For example, Ketil Trout exchanges verses with a troll-woman as they vie for power (Ketils saga hoengs $\mathrm{V}$ ), ${ }^{57}$ and while she says she does not fear his arrows, he kills her with one. Brynhild exchanges verses with a giantess at the gates of Hel, debating about the cause of Sigurd's death and insulting each other (Helreið Brynhildar, Poetic Edda 192-4; also told in Nornageststhattr IX 182-5). Brynhild wins the contest, and when she tells the giantess to 'sink down', the giantess jumps off the cliff. Brynhild's power with words is displayed earlier when she teaches Sigurd magical runes, and in the way she can manipulate Gunnar. Odd speaks in verses with the wicked priestess (ArrowOdd XXIX 113), and the volva answers Odin in verse in Völuspá (Voluspa, Poetic Edda 4-13). The magical power of words is illustrated in History. When Gro sees

\footnotetext{
${ }^{57}$ Gavin Chappell (trans.), The Saga of Ketil Trout. Retrieved from Northvegr Foundation. URL http://www.northvegr.org/lore/oldheathen/011.php Guðni Jónsson and Bjarni Vilhjálmsson (eds), Fornaldarsögur Norðurlanda (Reykjavík: Bókaútgáfan Forni: 1943-4). Retrieved from Perseus Collection: Germanic Materials. URL http://www.perseus.tufts.edu/hopper/text.jsp?doc=Perseus:text:2003.02.0026
} 
Gram and Bess coming she thinks it is her (despised) betrothed, so she flings up her reins and starts exchanging verses with both of them, in order to protect herself (History I [16-9] 14-7). More memorable is Gotvara, who is a 'warrior with words' and can quell anyone, and uses her ability to its fullest extent (V [118] 104) ${ }^{58}$ She is later punished for this, highlighting the transgressiveness of her actions.

While reciting words, as shown above, can have a powerful magical effect, it is not quite the same thing as casting a spell.

Witches are sometimes employed to cast spells. In Friðpjófs saga ins frokna, two witches are paid to raise a great storm against Fridjof, and go to the witchmount with spells and sorcery, later continuing their spell-casting on the back of a whale (Frifthjof V-VI 84, 91). ${ }^{59}$ In Book Seven of History, a woman with second sight is paid to find the two young boys who are hidden on the island by their foster-father, but when she is pulling them towards her they throw money into her lap so that she stops and pretends she cannot reach them (History VII [202] 182). In Hrolf Kraki it is their sister who throws a gold ring, and the seeress is so pleased she says that everything she had said previously was a lie (Hrolf Kraki III 7). Spell-casting is skill that can be bought by the highest bidder.

Spells are mostly cast for personal reasons, not always bad. An elf-woman deliberately lures Hrolf to her with a stag (Gongu-Hrolf XV 58) as her daughter will

\footnotetext{
58 'Pugnabat... verbis' lit. 'she fought with words'.

${ }^{59}$ Rasmus B. Anderson and Jón Bjarnason (trans.), Viking Tales of the North (Chicago: S.C. Griggs and Co., 1877). Guðni Jónsson and Bjarni Vilhjálmsson (eds), Fornaldarsögur Norðurlanda (Reykjavík: Bókaútgáfan Forni: 1943-4). Retrieved from Perseus Collection: Germanic Materials. URL http://www.perseus.tufts.edu/hopper/text.jsp?doc=Perseus:text:2003.02.0012 Chapters differ, and the translation is quite loose. 3 .
} 
die in childbirth unless touched by human hands. In History, Harthgrepa, Hading's giantess nanny-lover, inscribes gruesome spells on a piece of wood and has Hading insert them under the tongue of a corpse they find in a house. It is forced to tell them that they will be beset by demons in the wood, but also tells them that Harthgrepa will not survive, whereas Hading will (History I [23-4] 22-3). Also in History, Roller sees his mother stirring stew, with snakes hanging above providing saliva for it. She serves it to her two sons for wisdom, although they switch bowls and Erik gets the better stew. Erik later takes her with him on his travels due to her skill in magic (and her protection, mentioned in the Ch. 1: Magical Protection) (History V [124] 110).

Spells with malicious intent are far more common. They are useful in battle. In Book Eight of History, the witch Guthrun, with her magic, robs the king's defenders of sight and makes them turn their weapons on each other (History VIII [258] 235). Skuld uses magic in battle against her brother Hrolf and wins (Hrolf Krak [XXXIII] LI 76). Lara, the swan-maiden, howls with magic as she flies above the battle, so that people forget to protect themselves (Hromund VI 9).

Other examples of malicious intent are numerous. In History, Gotvara, the women with powerful words, weakens the Hunnish princess with words and an aphrodisiac (History V [120] 106). In the Volsung stories, Grimhild, who causes a lot of strife among the Gjuking clan, is 'well versed in magic' (Volsungs [XXVI] XXV 75). ${ }^{60}$ In Illugi, Sunnlod bewitches many men with her evil, and is used as a test of Illugi's endurance. When he kills her, Illugi's mother knows that he is ready to leave home (Illugi II 66). In Bosi and Herraud the priestess Kolfrosta travels to Glasir Plain by magic to take the princess Hleid, against her will, as her replacement

\footnotetext{
60 'Fjölkunngu'.
} 
(Bosi and Herraud VIII 211). None of these actions are benevolent in any way, but are at best protecting the spell-caster's kin.

In the riddarasögur spells can be used as a test. Möttuls saga and Skikkju rimur revolves around a beautiful cloak made by elf-women beneath the earth. If an unfaithful woman puts it on, it shrinks (Mottuls IV-X 12-27, Skikkjurimur III XILVII 299-309). ${ }^{61}$ This is very different from anything in the fornaldarsögur. While it shows up the men as foolish for trusting their wives, it portrays women in an especially bad light. This saga is judgemental about morality, which is generally uncharacteristic of native Icelandic literature.

\section{Knowledge/teaching of magic}

The teaching of magic, or wisdom, to a hero, can play a very important part in any saga. Brynhild in her valkyrie role is again a main example. She teaches Sigurd runes at great length, although she says he knows better than her (Volsungs [XXI] XX 67). Her counterpart, Sigrdrifa, will teach Sigurd 'powerful runes... how to speak every single human tongue, medicine' (Gripisspa XVII 145) ${ }^{62}$ She gives him a memory drink, full of 'spells and favourable letters, / good charms and joyful runes' (Sigrdrifumal V 167). ${ }^{63}$ Valkyries are closely associated with Odin, who is renowned for his wisdom. One of their roles seems to be to impart this to his heroes.

It is often the role of the foster-mother to teach magic. In Bosi and Herraud, Busla wants to teach Thvari's sons magic, but Bosi refuses (Bosi and Herraud II

\footnotetext{
${ }^{61}$ Marianne E. Kalinke (ed.). Norse Romance. Vol. 2: The Knights of the Round Table (Cambridge: D.S. Brewer, 1999).

62 'Hon mun ríkjum pér / rúnar kenna, /... ok á manns tungu / mæla hverja, / líf með lækning'.

${ }^{63}$ For Sigrdrifumal see: http://www.heimskringla.no/wiki/Sigrdr\%C3\%ADfum\%C3\%A11

'fullr er hann ljóða / ok líknstafa, / góðra galdra / ok gamanrúna'
} 
200). Groa, in Gongu-Hrolf, teaches Grim Aegir so much about witchcraft that noone in Scandinavia can rival him (Gongu-Hrolf II 31). Magic and wisdom are closely associated. Kostbera, in Volsungs, is able to look at Gudrun's runes and know that they are falsified, and that they warn of death (Volsungs [XXXV] XXXIV 97). Magical knowledge is sometimes actively sought out. The gods are known for doing this, especially Odin, but also Loki and Freyja. ${ }^{64}$ It is certainly no guarantee of a long and happy life. Odin is desperate to find out as much as possible about ragnarök, but in the end, despite all his planning and preparations, the doom of the gods is inevitable (Voluspa LIII-LVI 11).

\section{Magical corruption}

Corrupting a hero is about the worst thing a woman could do in heroic society, and there are plenty of cases of it involving magic. Sometimes corruption is sexual, sometimes it is due to poisoned food or drink, but it is nearly always due to the deliberate actions of the female and the weakness of the man.

Magical drinks are very common. They vary from love potions to fatal poisons. Love potions can be extremely dangerous. The love potion sent by the Irish queen for her daughter and the king to drink on their first night together, and the mistake of Tristram and Isond drinking it, is the axis of all the Tristram sagas (Tristram ok Isondar XLVI 119-121; Saga af Tristram ok Ísodd X 277). ${ }^{65}$ In History, Gotvara gives the Hunnish princess an aphrodisiac to make her stop

\footnotetext{
${ }^{64}$ For example, Odin in Voluspa, Freyja in Hyndluljóð (Poetic Edda 3-13, 253-259), Loki from Frigg in Gylfaginning (Gylfaginning XLIX, Poetic Edda 48).

${ }^{65}$ Marianne E. Kalinke (ed.). Norse Romance. Vol. 1: The Tristan Legend. Cambridge: D.S. Brewer, 1999.
} 
despising Frothi (V [120] 106). Kraka offers Alvild a drink which makes her desire Frothi (V [139] 124). Helgi, in Helga pattr Pórissonar, comes across women who give him food and drink, and offer to sleep with him. Later, one of them gouges his eyes out (Helgi Thorisson I 276-7, III 280) ${ }^{66}$ Valkyries are carriers of love potions with the aim of war: in Sörla páttr Hedin drinks from Gondul's horn, becomes filled with lust and does what she urges. Hild, the girl he kidnaps, knows that he is spellbound (Sorli VII 80-1). ${ }^{67}$ Similarly, when Viking in Thorstein Vikingsson meets Solbjort, he drinks from her horn, falls asleep, and then forgets his past, especially his beloved Hunvor (Thorstein Vikingsson V 11). Poison comes up yet again in Illugi's saga, where Grimhild kills the king with poison in order to have a younger man. Every night a man in the kingdom disappears, and it is thought to have to do with Grimhild. Possibly she is poisoning them as well (Illugi V 70).

Volsungs contains many magical potions. Borghild serves Sinfjotli a poisoned drink. Sigmund, who is immune to poison, consumes it the first two times, but the third time she brings it Sinfjotli gives in, and at Sigmund's suggestion to 'filter it through your moustache' he drinks it himself, and dies. Sigmund, in consequence, drives out his queen, and she dies soon after (Volsungs X 51). ${ }^{68}$

\footnotetext{
${ }^{66}$ Hermann Pálsson and Paul Edwards (trans.), Seven Viking Romances (London: Penguin, 1985). Guðni Jónsson and Bjarni Vilhjálmsson (eds), Fornaldarsögur Norðurlanda (Reykjavík: Bókaútgáfan Forni: 1943-4). Retrieved from Perseus Collection: Germanic Materials. URL http://www.perseus.tufts.edu/hopper/text.jsp?doc=Perseus:text:2003.02.0019

${ }^{67}$ W. Bryant Bachman, Jr and Guðmundur Erlingsson (trans), Six Old Icelandic Sagas (Lanham, Maryland: University Press of America, 1993). Guðni Jónsson and Bjarni Vilhjálmsson (eds), Fornaldarsögur Norðurlanda (Reykjavík: Bókaútgáfan Forni: 1943-4). Retrieved from Perseus Collection: Germanic Materials. URL http://www.perseus.tufts.edu/hopper/text.jsp?doc=Perseus:text:2003.02.0032

68 'Lát grön sía, sonr'.
} 
Brynhild does not give Sigurd a love potion, but, as mentioned above, she does give him a memory drink when she teaches him the runes, and by the end of this encounter in at least one version they are betrothed (Volsungs [XXI] XX 67).

Grimhild is the main administrator of magical potions, particularly potions of forgetfulness. Brynhild predicts that Grimhild will give Sigurd bewitching mead (Volsungs [XXVII] XXV 77), ${ }^{69}$ and so she does: although she sees how much Sigurd loves Brynhild, Grimhild gives him a drink which makes him forget her (Volsungs [XXVIII] XXVI 78). Brynhild later blames Grimhild for bringing Sigurd the ale, although she also berates Gudrun (Volsungs [XXX] XXVIII 84). Grimhild's potions continue with Guttorm, as she gives him evil food and uses witchcraft so that he agrees to kill Sigurd (Volsungs [XXXII] XXX 89-90). The final potion goes to Gudrun, in order to make her forget her grievances against her family (Volsungs [XXXIV] XXXII 94). This reinstates her loyalty, whereas the result might otherwise have been revenge, such as that which Kriemhild takes in The Nibelungenlied, egging Atli on to kill her brothers. ${ }^{70}$ In the prose passage Dráp Niflunga, it is Gunnar and Hogni who give Gudrun the potion, so that she will marry Atli and reinstate peace between the two clans (Niflungs, Poetic Edda 195). However, in Gudrun II, it is definitely done by Grimhild (Gudrun II XXI-XXIV 199).

Flesh, as well as drink, can have magical properties, mentioned above with Guttorm given 'evil food'. Sigurd and Gudrun consume some of Fafnir's heart, which makes them 'grimmer and wiser' (Volsungs [XX] XIX 66, [XXVIII] XXVI

\footnotetext{
69 'meinblandinn mjöð'.

${ }^{70}$ George K. Anderson (trans.),The Saga of the Volsungs, together with excerpts from the Nornageststhattr and three chapters from the Prose Edda (Newark: University of Delaware Press, 1982), p.201.
} 
79). ${ }^{71}$ In Hrolf Kraki, Bera is forced by Hvit to eat some of the bear meat which is the transformed flesh of her lover, and this causes her children to have animal-like qualities ([XX] XXVII 39-40). ${ }^{72}$

\section{Shape changing}

Shape changing is a definite sign of magical ability, and is surprisingly common. Perhaps this is because it links in with Old Norse mythology: valkyries / shield maidens such as Svava are able to fly, and sometimes they turn into swans, as do Svanhvit and her sisters (Völundarkviða I-III, Poetic Edda 103). Wish-maidens, such as the one who acts on behalf of Odin in giving an apple to Rerir (Volsungs [I] II 36), are also able to shape change; she flies in the form of a crow. Performing tasks set by Odin entitles these women to special abilities, especially flying. Some of the Ásynjur also have this ability, such as Freyja who is able to take on a 'falcon shape' (Skaldskaparmal III, Prose Edda 60). ${ }^{73}$ Sometimes they transform, and at other times put on a feather cloak (Prymskviða III, Poetic Edda 97).

Swan maidens can be both good and evil. Certainly Svava/Sigrun is on Helgi's side, but she is also a powerful foe in battle (Helgakviða Hundingsbana I XXX, Poetic Edda 118). Swans sing about Fridlef in Book Six of History, although a belt has to fall from the sky inscribed with letters for him to understand the song (History VI [166-7] 147). Brynhild herself makes an allusion to being a swan

\footnotetext{
71 'Grimmari en áđr ok vitrari'.

${ }^{72}$ Specifically, Elk-Frodi, who is an elk below the navel; Thorir, who has dog's feet from his insteps down, and Bodvar, who in battle is able to project a bear to fight for him.

73 'valshams'.
} 
maiden in Brynhild's Hel-ride (VI 193). ${ }^{74}$ Lara, Helgi the Bold's mistress in Hromund, is a swan in battle, and flying above manages to turn the fighting against the heroes, until she is accidentally killed by her lover (Hromund VII 10). Larrington says in her introduction to the Poetic Edda that the swan cloaks cause the transformation for swan maidens. ${ }^{75}$ In Volund, the three brothers find three women spinning linen, who have swans' garments nearby, as they are valkyries. Although they are grounded for several years, eventually they take on their swan form again (Volund I-III, Poetic Edda 103).

Sometimes direct exchanges happen with shape-changing. In The Saga of the Volsungs, for example, Signy asks the sorceress to change shapes with her, so that her husband will not know she is missing, and so that Sigmund will not know that she is his sister (Volsungs VII 43). Whether Signy has to ask because it is a direct swap, or because she herself does not have shape changing abilities, is unclear. Her brother and son also change shapes when they become wolves (VIII 44-5). There is another direct exchange between Ingeborg and the troll Skellinefja, brought about by Skellinefja's brother (Thorstein Vikingsson XVII 47). This, however, is definitely unwilling on the part of Ingeborg, and we never know what Skellinefja's opinion is.

Sometimes characters change into an entirely different species when they change shape. Examples of complete change include a troll-woman turning into a whale (Ketil Trout V), the she-wolf being said to be Siggeir's mother (Volsungs [VI] $\mathrm{V}$ 42), the giantess in Ironwood breeding many giants as sons, all in wolf shape (Gylfaginning XII, Prose Edda 15), Loki going as a mare to distract Svadilfaeri, and

\footnotetext{
${ }^{74}$ This verse is in a different place in the online edition, at verse VIII.

${ }^{75}$ Larrington p. xvii.
} 
giving birth to the eight-legged foal Sleipnir (Gylfaginning XL, Prose Edda 36), Loki taking on Freyja's falcon shape to look for Idunn, and turning Idunn into a nut (Skaldskaparmal III, Prose Edda 60) and in History the woman who changes herself into a mare, then a sea-cow, and changes her sons into calves (History V [157] 142). It is not explained what Dis, the shape-changer (eloquently translated as ham-leaper, or skin-leaper), changes into, other than the beautiful maiden Solbjort (Thorstein Vikingsson V 11), but the saga says there is no troll such as her (Thorstein Vikingsson V 13).

A notable exception in this shape changing is Hading's nurse Harthgrepa, a giantess. Rather than actually changing her form, she tells Hading that she can change shape and size (History I [22-3] 21-2). This enables her to be his lover, despite the fact that she is a giantess, but it also means that when he calls on her for help she is able to swell to giant size (I [24] 23). The giantess foster-mothers / lovers of sagas such as Hrafnhild in Ketil Trout and Hildigunn in Arrow-Odd' are presumably also able to change their shape and size (Ketil-Trout III; Arrow-Odd XVIII 76-77), although it is not explicitly mentioned. ${ }^{76}$

\section{Interaction with the dead}

There are three main examples of women interacting with the dead in Old Icelandic heroic and mythological literature. Perhaps more could have been expected, considering that Freyja can take half of the warriors from the battlefield as her own (Gylfaginning XXIV, Prose Edda 24), and valkyries are predominantly associated

\footnotetext{
${ }^{76}$ Davidson associates Harthgrepa with Boethius' Dame Philosophy, who in her shape changing represents the possibilities of language and is a display of Saxo's erudition (History II pp. 29-30, note 26).
} 
with dead warriors (Gylfaginning XXXVI, Prose Edda 31). Nonetheless, the examples that exist are very precise.

In Heidrek, Hervor is determined to regain the magical (and cursed) sword Tyrfing from her father. The fact that he is dead does not deter her in the slightest, although the shepherd leaves the island in terror, and her fellow vikings will not leave the ship (Heidrek III 12-13). Hervor commands the undead to awake, and even threatens to curse them if they do not give her the sword she desires (Heidrek III 1415). Angantyr and his brothers arise in flames from their graves, but Hervor remains steadfast (Heidrek III 16). She intimidates them, even when she is warned that things will go badly for her descendents, and she ultimately gets the sword and is satisfied (Heidrek III 18). It is surprising that such a formidable character should quickly afterwards get married and fade into the background of the saga (Heidrek IV 20). This is perhaps due to the integration of the earlier poem into the later saga. The difference between Hervor and Gongu-Hrolf, who is able to get weapons and help from a burial mound relatively easily on two occasions (Gongu-Hrolf XVI 61-2, XXXII 104-5), is essentially gender. Both, however, are less violent encounters than Hromund's in Hromund's Saga battling the dead berserk in his mound (Hromund IV 6-7)

A rather more chilling, and more mysterious interaction with the dead is when Sigrun visits Helgi in the grave in Helgakviða Hundingsbana II. She prepares a bed and wants to sleep with him, but he seems horrified at the idea and rides away with his men, never to return. Before too long she dies of grief (Helgi II XLIII-LI, Poetic Edda 139-141). Whether he is not permitted to interact with her or chooses 
not to is unclear. It shows that there is definitely a separation between valkyries and shield-maidens, as valkyries are expected to interact with the dead: presumably it is not permissible for their human counterparts. The taboo may be limited to sexual encounters. ${ }^{77}$

The third motif comes up a couple of times, all in association with a woman named Hild, a typical name for a valkyrie, who certainly seems to be acting in a valkyrie-like manner. In Skaldskaparmal, at night Hild wakes the dead by magic, so that they can fight all the next day (Skaldskaparmal LXII, Prose Edda 123). In a more emotional version in History, after her husband died Hild would long for him so much that she would conjure up the spirits of dead men at night so that they could resume their fighting (History V [149] 134). Finally, in Sorli, the princess Hild (not a valkyrie) is forced to watch her father Hogni battle Hedin day after day for one hundred and forty-three years, instigated by the valkyrie Gondul (Sorli VIII 83). None of these interactions with the dead have good results, but all bring about death and increased woe.

\section{Conclusion}

Women of all sorts use magic in the fornaldarsögur, as a standard part of the romance world that these sagas are set in. It is presented as natural, in a matter-offact manner. Influence can be seen from Norse mythology, especially the asir, but there are some unique features as well, such as the role of the troll-wife caring for the hero, and the educational role of foster-mothers. While many of these motifs are also found in Saxo's History, magic is encountered far less in the riddarasögur,

\footnotetext{
${ }^{77}$ See Ch. 2: Death and Desire.
} 
although these are also romances. The Icelandic world, on the whole, seems to accept the supernatural relatively easily, and the role of women in this is seldom questioned. 


\section{Chapter Two: Women and Sexual Transgressions}

\section{Introduction}

In medieval literature, a woman's role in life is primarily to be a faithful wife, or a good and chaste daughter if unmarried. Yet, in the selection of texts I have looked at, there is a considerable focus on how women flout this role. There are frequent stories of adultery and fornication, seduction, promiscuity and wanton behaviour, as well as more profound transgressions, such as incest. Many of the women are very independently minded. Women have conflicting loyalties, and are divided over whether to put themselves, their children, husbands or natal families first, or sometimes their lovers. The attitude to sexuality differs from the riddarasögur to the fornaldarsögur to Saxo's more judgemental history, even though there are many parallels, particularly between the last two.

\section{Incest}

Incest is probably the most developed and interesting sexual transgression, as the motif comes up with some frequency, and is usually central to the plot, often engendering heroes. The woman involved usually brings it about intentionally. It occurs in some of the most famous of the fornaldarsögur, namely, Hrolf Kraki and Volsungs, as well as in analogues and other stories in History, and in the mythology. Incest occurs between siblings, parent and child and foster-parent and fosterling, as well as between in-laws. The vanír treat it as normal, but it can be an act of desperation, as in Volsungs, or of malice, as in Hrolf Kraki. In other fornaldarsögur 
it is a point of humour, and one of the hero's many adventures. The different ways in which incest is treated reflect the tone of each text. As with any adultery, incest would leave husbands without a definite idea of whether their wives' children were their own, and the succession would be uncertain. On the other hand, the close relationship of a 'sister-son' would be strengthened if it could be 'sister-and-selfson', making an even stronger alliance with no conflicting loyalties. Great heroes come out of incest. ${ }^{78}$

\section{Mythology}

Incest is an acknowledged characteristic of some of the asir. Most pantheons are somewhat incestuous, as there is usually little scope for anything but intermarrying. This is emphasised in Heimskringla, which says that when Njord was in Vanaland he had taken his own sister in marriage as that was allowed by their law, and that their children were Freyr and Freyja. It goes on to say that in Asaland people were forbidden to marry such near relations (Ynglinga Saga IV, Heimskringla 9). Loki accuses Freyja of incest with her brother Freyr in Lokasenna, but Njord defends her, saying 'that's harmless, if, besides a husband, a woman has a lover or someone else'. Loki goes on to accuse Njord of fathering his son Freyr on his sister (Lokasenna XXXII-XXXVI 90-1). At one point he also accuses Frigg of sleeping with one of Odin's brothers (Lokasenna XXVI 89), which is reported in Ynglinga saga (Ynglinga Saga III, Heimskringla 8). As Loki is obviously stirring up trouble, we are probably supposed to feel sympathy for the vanír, who are, after all, fertility gods.

\footnotetext{
${ }^{78}$ Georges Dumézil, From Myth to Fiction: the Saga of Hadingus (Chicago and London: The University of Chicago Press, 1973), p. 53.
} 
However, Loki's accusations of incest do suggest that from the point of view of the asir , and the human audience, incest would be taboo.

\section{Hrolf Kraki}

There are variations on the story of incest between Helgi and Yrsa in Hrolf Kraki and its analogues, but they follow the same plot in essentials. The incest is always deliberately plotted by Yrsa's mother as revenge on Helgi, and Hrolf Kraki is always the offspring of the union.

In Hrolf Kraki, Helgi plots an ambush and rapes Olof after she has made a fool of him. When she offers to marry him now, he turns her down and leaves her full of hate towards him. She secretly gives birth to Yrsa but does not acknowledge her as her child. She plots to have Helgi come across Yrsa, and Helgi subsequently falls in love with her and makes her his queen (Hrolf Kraki [VI-VII] VII-IX 13-16). Years later, Olof deliberately spoils their happiness by coming to Yrsa and telling her the truth about their relationship. Yrsa leaves Helgi and refuses to return to him, so they are both unhappy (Hrolf Kraki [X] XIII 20-1). However, Yrsa remains loyal to her son by Helgi, Hrolf, and helps him rather than her new husband Adils when Adils betrays him (Hrolf Kraki [XXVIII-XXIX] XLI-XLIV 62-6).

In Heimskringla, nothing is told of any meeting between Alof and Helge. It is Adils who plunders Alof's house and takes Yrsa as his queen, who is in turn taken by Helge. When Alof tells Yrsa about her parentage, Yrsa returns to Adils (Ynglinga Saga XXXII-XXXIII, Heimskringla 29). 
In History there are some significant differences, the main one being Yrsa's knowledge of the incest. Thora (rather than Olof) is a virgin raped by Haldan. Years later, she 'deliberately' sends her daughter to him, and instructs her to seduce her father. Saxo tells us that she cared nothing for the purity of her kin as long as she made him guilty of incest, as she had a depraved female mind. She accumulated guilt, believing she was gaining vengeance. She 'played the step-mother to her child' (History II [51] 47). ${ }^{79}$ Again, Yrsa gives birth to Rolf, and is later loyal to him over her husband Athisl. She is referred to as both Rolf's mother and sister, and Athisl accuses them of 'wanton' behaviour for sitting next to each other (History II [52-3] 48-9). ${ }^{80}$ It is not stated whether the incest is ever revealed to Helgi, but he does loathe his homeland 'because of the shameful thing he had done', and possibly commits suicide (History II [52] 48). ${ }^{81}$

There is one other episode of attempted incest in Hrolf Kraki. Hvit makes advances on her husband's son, but is spurned. In consequence of the rejection, she turns Bjorn into a bear and incites the king, his father, to kill him, thus making him guilty of killing his son and heir (Hrolf Kraki [XIX-XX] XXV 36-7). She also ensures that the king's grandsons will be unable to rule by feeding Bjorn's flesh to Bera, which makes their sons misfits (Hrolf Kraki [XX] XXVII 39).

\section{Volsungs}

The Saga of the Volsungs contains some very well known incest scenes. However, unlike the story of Hrolf Kraki, they do not appear in its analogues. The motif first

\footnotetext{
79 'de industria', 'subolis suæ novercam agendo'.

80 'lasciviæ'.

81 'ob superioris flagitii ruborem'.
} 
occurs with the conception of Volsung. His parents are unable to get pregnant by natural methods, and so, at their prayer, Odin sends a wish-maiden with an apple. Rerir eats it, visits his wife, and Volsung is conceived (Volsungs [I] II 36). Later, Volsung marries the same wish-maiden (Volsungs II 37). With the wish-maiden's role in Volsung's conception, this seems at least to foreshadow the oncoming incest of his children. ${ }^{82}$

The incest of Signy and Sigmund is an act of desperation. Their first priority is to avenge their father and brothers, and to do this, Sigmund needs a companion. ${ }^{83}$ Signy's first two children by Siggeir show cowardice (Volsungs VI 42), and so are not worthy, and perhaps would not have the ability, to be involved in the revenge of the Volsungs. In order to give birth to someone with the necessary tenacity, Signy has to defile herself by changing shapes with a witch, and sleeping with an unsuspecting Sigmund (Volsungs VII 43). The result is the fearless Sinfjotli, and the Volsungs achieve their desired revenge (Volsungs VIII 47). In bringing about the death of all her children by Siggeir his line is extinguished, and he would know that nobody would avenge him. Signy's line is also later extinguished, as Sinfjotli is killed by Sigmund's wife without producing any offspring (Volsungs X 51). ${ }^{84}$ However, the Volsung line, which would probably have been the most important thing for Signy, continues with Sigmund. The bachelor Hrolf Kraki also dies without leaving any progeny (Hrolf Kraki [XXXIV] LII 78). ${ }^{85}$ Presumably, while incest can

\footnotetext{
${ }^{82}$ Byock, Volsungs, p. 9.

${ }^{83}$ Why Signy could not herself kill Siggeir in bed is probably a matter of rank - so long as her brother was alive, it was his task to perform. When Gudrun killed Atli, she did this with Hogni's son. They were the last of their clan to be able to take revenge.

${ }^{84}$ At least, we are not told of any offspring.

${ }^{85}$ LII.
} 
produce great heroes, it is not to be desired as the foundation of a dynasty. ${ }^{86}$ Signy appears to be greatly ashamed of her incest, and it is one of the reasons she ends her life (Volsungs VIII 47) ${ }^{87}$ Byock suggests, as seems likely, that incest is in fact a later addition to the legend. ${ }^{88}$ In Beowulf, Fitela is Sigemund's nephew, rather than son. ${ }^{89}$ As Volsungs is the only remaining record of the Signy story it is impossible to say what, if any, precedents there were. ${ }^{90}$

Incest is hinted at later on in the Volsung stories, regarding Svanhild and Aslaug, both daughters of Sigurd. Svanhild is escorted by the son of her betrothed husband, and when their companion suggests that the prince would be a more suitable husband, they are said to respond to this positively: whether they act on this is not stated, but they are both executed because of it (Volsungs [XLII] XL 106-7). In Ragnarssons one of Aslaug's stepsons, at his death, wants word sent to his 'slender' sweet stepmother (Ragnarssons II). ${ }^{91}$ His choice of words shows some physical attraction. Reading incest into this is going too far, but it does hint at the different sorts of relationships that could be present in a step-family, with the wife often closer to the age of her husband's children than her husband.

\footnotetext{
${ }^{86}$ Wagner's take is of course different: the two lovers produce Siegfried, who goes on to have the role of Sigurd. Nonetheless, his line is still doomed, and there is no mention of Aslaug or any other children.

${ }^{87}$ See Ch. 4: Suicide.

${ }^{88}$ Byock, Volsungs, pp. 21-2.

${ }^{89}$ George Jack (ed.), Beowulf: A Student Edition ( New York: Oxford, 1994), pp.78-9, 11.874b-892.

${ }^{90}$ Suggestions have been made linking Signy both to Hildeburh in Beowulf and the woman in the Old English poem known as Wulf and Eadwacer. Although interesting suggestions, the evidence is not entirely convincing. For more, see Robert A. Alano, 'The role of women in Anglo-Saxon culture: Hildeburh in Beowulf and a curious counterpart in the Volsunga Saga', English Language Notes 32.1 (1994): pp. 1-10 ; Richard North, 'Metre and Meaning in Wulf and Eadwacer: Signy Reconsidered'. Loyal Letters: Studies on Mediaeval Alliterative Poetry and Prose, ed. L.A.J.R. Houwen and A.A. MacDonald (Groningen: Egbert Forsten, 1994) pp. 29-54 ; William H. Schofield, 'Signy's Lament', Publications of the Modern Language Association of America 17.2 (1902), pp. 262-295.

91 'Mjó'.
} 
Saxo largely presents a negative view of incest, as being a crime, either legal or moral. Svanhild is charged (unfairly) with incest, and executed for it (History VIII [257] 234), and Fengi, after killing his brother, 'added incest to fratricide' by taking his wife (History III [83] 80). ${ }^{92}$ Amleth is harsh on his mother Gerutha for submitting to Fengi, comparing her to a mare, clasping her 'husband's murderer to [her] incestuous bosom' and telling her to weep for herself, not him (History III [867] 81). She is recalled to the practice of virtue (History III [87] 81), and, once he is reinstated, Amleth tells his people to 'commiserate too with my unfortunate mother and, as she was once your queen, rejoice that her disgrace is expunged... she was forced to submit her woman's body to a double weight of shame' (History IV [95] 86) ${ }^{93}$ Gerutha is a victim of this incest, and yet Amleth holds her accountable.

Foster-relationships are less clear cut. In Book One of History, Gram marries his foster-sister, with whom he was 'nourished at the same breast', before he marries her on to someone else (History I [16] 13)..$^{94}$ There is no suggestion of this relationship being reprehensible in any way. This motif recurs in the quirky story of Harthgrepa and Hading, with the foster-mother giantess seducing her charge. Moreover, Harthgrepa uses the fact that she had nursed him as justification for them to be lovers, emphasising the incestuous nature of their relationship (History I [22] 21). ${ }^{95}$ Similar stories with troll-lovers crop up in the fornaldarsögur, particularly

\footnotetext{
92 'Incestum parricidio adiecit'.

93 'Miseremini quoque afflictæ genetricis meæ, et reginæ quondam vestræ exstincto congaudete dedecori... geminum ignominiæ pondus femineo perpeti corpore cogebatur'.

94 'Collactaneam' literally 'co-milked', used as a term for foster-sister.

${ }^{95}$ Dumézil uses this to argue that there is a parallel between Hading and Njord, because only among the vanír could this strengthen an argument for marriage (Dumezil p. 60).
} 
with reference to the men of Hrafnista (Arrow-Odd, Ketil Trout, and Grim ShaggyCheek), who are all part-troll. Arrow-Odd, for example, when taken into Hildir's family is put in a cradle by Hildigunn, who thinks he is a baby because he is so much smaller than her. After a while 'she put him in her bed beside her and embraced him. Eventually Odd played all the games he felt like, and after that they got on very well together' (Arrow-Odd XVIII 76). At the end of the winter when he is leaving, Hildigunn says she would like him to return as 'I can't fool myself any longer that I'm not pregnant, though it might seem unbelievable that a useless little thing like you could do so much. But there's no one else involved who could be the father of the child I'm carrying' (Arrow-Odd XVIII 77). ${ }^{96}$ In this case, however, it is Odd who initiates the union. The emphasis in this story is more on the difference in size, rather than the relationship of nanny and baby. This story is a comic episode in Odd's adventures, which continues at the meeting of Odd with his ten-year-old son, who also ridicules him for his size (Arrow-Odd XXI 85). Saxo's version highlights the incest far more strongly.

\section{Death and Desire}

This motif occurs only once, which seems a shame as it is one of the more tragic, romantic and mysterious scenes in Old Icelandic poetry. ${ }^{97}$ In Helgi II, Sigrun's maid

\footnotetext{
96 'Parf ok eigi við pat at dyljast, at ek em með barni, pó at pat mætti ólíkligra pykkja, at pú værir til peira hluta færr, svá lítill ok auvirðiligr sem pú ert at sjá. Er par pó engi í tigi til nema pú at vera faðir at barni pví, er ek geng með.'

${ }^{97}$ See Ch. 1: Interaction with the Dead and Ch. 4: Post-death. A comparable folktale, 'The Lovers', records the story of a young couple separated by the death of the man. She has disturbed dreams, and when a 'wise' old woman helps her, her lover comes to her window and tells her of his death, and that he will never be able to visit again because she locked him out. The girl goes crazy and never totally recovers. Jacqueline Simpson, Icelandic Folktales and Legends (London: BT Batsford Ltd, 1972) pp. 107-8.
} 
sees the dead Helgi returning to his burial mound (Helgi II XL, Poetic Edda 139).

She sends Sigrun to the mound, who greets Helgi, saying 'First I want to kiss the lifeless king' (Helgi II XLIV, Poetic Edda 140). ${ }^{98}$ She makes up a bed in the mound, saying:

'Here I've made for you, Helgi, a bed all ready; descendant of the Ylfings, now free from care in your arms, lord, I'll sleep, as I would with the prince, when he was living.' (Helgi II XLVII, Poetic Edda 140) $^{99}$

His reply is: 'I say that nothing could be less expected...that you should sleep in the arms of a dead man...and you alive' (Helgi II XLVIII, Poetic Edda 140). ${ }^{100}$ Helgi then tells Sigrun it is time for him to leave, and he goes, never returning (Helgi II XLIX, Poetic Edda 140). While it is not clear whether anything sexual happens between them, it seems that he turns down her offer. Her wishes are clear. He does, however, suggest that they drink together (Helgi II XLVI, Poetic Edda 140). The borders between life and death are fuzzy, and drinking with the dead is not so very far removed from greater intimacy. ${ }^{101}$ This scene could be euphemistic for lovemaking. A sexual relationship with the waking dead seems to be unmentionable, while it may not be inconceivable. It would be a transgression from life to death which might be impossible to return from, and indeed Sigrun does not really return, but dies soon after.

\footnotetext{
98 'Fyrr vil ek kyssa / konung ólifðan'.

99 'Hér hefi ek pér, Helgi, / hvílu görva / angrlausa mjök, / Ylfinga niðr, / vil ek pér í faðmi, / fylkir, sofna / sem ek lofðungi / lifnum myndak.'

100 'Nú kveð ek enskis / örvænt vera /... er pú á armi / ólifðum sefr /... ok ertu kvik'.

${ }^{101}$ Relevant folktale motifs are C262 Tabu: drinking in otherworld; E310 Dead lover's friendly return; E474 Cohabitation of living person and ghost. There is no specific reference to eating or sleep with the dead. Inger Margrethe Boberg, Motif-Index of early Icelandic Literature (Copenhagen: Munksgaard, 1966), pp. 51, 95, 99.
} 
Unions between the dead and the living may be taboo, but certainly there is an expectation that lovers are reunited in death. ${ }^{102}$ When Baldr dies, Nanna does the same shortly after, and we see her both her and Baldr with Hel (Gylfaginning XLIX 49-50). Brynhild believes that she will be with Sigurd in the afterlife (Brynhild XIV, Poetic Edda 194), and Hagbarth believes that he and Signe will have a union in the next world (History VII [217] 198). No mention is made of this in the case of Helgi and Sigrun, but it is stated more than once that they are reborn (Helgi Hi, Helgi II, Poetic Edda 131, 133, 141). Unfortunately, their ill fate seems to follow them in each of their incarnations.

\section{Disloyalty to family due to romantic relationship}

Women are frequently in the position of having to prioritise their loyalties. Usually their allegiance to their natal family gets top priority, but this is not always the case. There are many examples of women choosing their husband over their kin, or a man they think is more suited to them than the prospective husband their family has chosen.

In Arrow-Odd, Olvor agrees to marry Odd, although he has killed her father and three brothers (Arrow-Odd XII 55). She wants him to stay to protect her kingdom as there had been so much strife since her male kin died, but he will only stay if she agrees to marry him, so she does.

\footnotetext{
${ }^{102}$ A more snide reference is made when Gunnild kills herself after her husband's death, and she lies 'embracing her husband in the companionship of the tomb, rather more nobly than in the marriagebed'. (History I 27). Other analogues can be seen in the death of Tristram and Isond, when Isond the Dark tries to keep them apart in death by burying them on opposite sides of the church, but trees grow from each grave and intertwine overhead. (Tristram ok Isondar CI 223, Tristrams kvæði XXVI 237, XXX 239).
} 
In Halfdan, Queen Isgerd is initially unwilling to marry Eystein, who had killed her husband in battle, but she does so without too much persuasion (Halfdan III 173). Amleth's mother also marries her husband's slayer, ${ }^{103}$ but unlike Gerutha, Isgerd's transgression is not condemned. Whether or not Isgerd is happy to be married to him is not specified, but she warns him to be on his guard when she knows of an assassination plot, and so is disloyal to the memory of her husband, and her living daughter (Halfdan VIII 179).

In Bosi and Herraud, the princess Hleid is quite happy to marry Herraud if he will take her away from the priestess' temple, but when she says she would like her family's approval he is not at all worried about this, and she accepts this, and put him above her family loyalties (Bosi and Herraud VIII 214). This leads to the death of Herraud's father King Hring and a lot of his army, as the man Hleid's family want her to marry pursues her (Bosi and Herraud X 216). Bosi and Herraud's next adventure is to get Hleid back. While it may not have been the princess's fault that she could not do as her family would have wished, the results are certainly dire.

Sigrun, in the Helgi poems, has conflicting loyalties between her lover Helgi and her family. She had loved Helgi before she saw him (Helgi II XV, Poetic Edda 135), but she fears the anger of her family as she is betrothed to Hodbrodd, and loving Helgi she is breaking her father's word (Helgi II XVI, Poetic Edda 135). Like Herraud, Helgi is less concerned about this than his lover, (Helgi II XVIII, Poetic Edda 135) and, as with Herraud, his attitude helps to bring about disaster. Sigrun curses her brother Dag for killing Helgi (Helgi IIXXXI-XXXIII, Poetic Edda 138), ${ }^{103}$ See Ch. 2: Incest. 
and her brother tells her that she is mad (Helgi II XXXIV, Poetic Edda 138), indicating that her choice of lover over family is not what was expected.

This lack of loyalty can even occur within a marriage. In History, a princess who is in love with Snio plans to leave her husband the Swedish king, even though Snio had defeated her father in battle. She and Snio have a beggar go between them to sort out arrangements to meet, and she is taken away on a boat, along with the king's treasure. The two kings fight over her for some time. Her loyalty is only to herself and her lover, whom she had loved before being forced to marry the Swedish king (History VIII [258-9] 235-6). Saxo does not invite us to sympathise, but speaks of the girl as Snio's 'unlawful possession' (VIII [259] 236).

In History, Signe falls for Hagbarth, and they become lovers even though he killed two of her brothers in retaliation for them killing two of his (History VII [214] 194-5). In bed, Hagbarth asks her if she would be true to him if he were condemned by her father. She says she would die with him, and this matters more to him than his own pending death (History VII [215]). ${ }^{104}$ They are a 'Romeo and Juliet' type of couple, in that the feuding between the families brings about the untimely death of their children.

An example in mythology of a daughter choosing her lover over her father can be found in the story of Gunnlod and Odin. After Odin, under the pseudonym Bolverk, sleeps with her for three nights, Gunnlod lets him drink three draughts of the treasured mead of wisdom which her father had given her to guard. In these three

${ }^{104}$ See Ch. 4: Suicide. 
draughts he consumes it all, then flies away. He had had no interest in Gunnlod, and approaching her was one of his several attempts to gain the mead (Skaldkaparmal VI, Prose Edda 63). Gunnlod puts her feelings towards her lover above her loyalty to her father, and she is shown to have misjudged, so that the episode illustrates the perceived susceptibility of women.

\section{Adultery}

Adultery is one of the more serious common sexual transgressions. ${ }^{105}$ Aside from being a major slight against the husband, it means that his line of succession is also uncertain. With the importance placed on kinship in Norse society, this is a major issue. Adultery, while it comes up in some native Icelandic texts, is found especially in the translated romances of Arthurian legend.

Hávamál warns to 'be most wary of ale, and of another's wife' (Havamal CXXXI, Poetic Edda 33), ${ }^{106}$ and 'never entice another's wife to you / as a close confidante' (Havamal CXV, Poetic Edda 30). ${ }^{107}$ Whether this is because women cannot be trusted, or because their husbands will take revenge, is unclear. However, the intent is the same: close relations with somebody else's wife are not advised.

Heidrek includes an adulterous incident, but the emphasis is mostly on the fact that Heidrek's wife lowered herself by committing adultery with a servant (Heidrek VII 27). It does not impact greatly on Heidrek or the plot. When, in History, Frigg commits adultery with a servant, Odin goes into exile due to the shame, and he only recovers his name with her death (History I [26] 25). Death is

\footnotetext{
${ }^{105}$ For incestuous adultery, see Ch. 2: Incest.

106 'Ver pú við öl varastr / ok við annars konu'.

107 'annars konu / teygðu pér aldregi / eyrarúnu at'.
} 
not uncommon as a possible end to adultery. In Hálfs saga ok Hálfsrekka, when Asa betrays her husband Hjorleif, he kills Hreidar, Asa's new lover, and at the subsequent Thing Asa is sentenced to be drowned in the swamp. Luckily for her Hjorleif shows compassion, and sends her and her dowry to the mountains instead, enabling her to start anew (Half VIII 12). ${ }^{108}$ Gotvara is stoned to death for knowing about Hanunda's adultery, which she herself had instigated (History V [136] 122), but Hanunda, after admitting her guilt, is married to Roller (History V [130, 137] $116,122)$. An expression of regret can make a difference to the outcome. In the same book of History it is decreed that adulterers (the male partners) should be 'deprived of their members' by the husbands of their lovers (V [143]). ${ }^{109}$

It is more common for an adulterous woman to leave her husband for good than to go back to him. One exception occurs in Gongu-Hrolf, but in this case Ingibjorg had been bewitched, so when Mondul takes her to bed with him every night in front of Bjorn she has no memory of her husband, and when her senses are restored she returns to him (Gongu-Hrolf XXIII 78, XXV 84).

Women are sometimes wrongly accused of adultery. It is a powerful accusation to make: Svanhild is trampled for alleged adultery, although not even married (Volsungs [XLII] XL 107). Loki, in Lokasenna, says Tyr's wife had a son by him, although this is denied (Lokasenna XL, Poetic Edda 91). As he puts this in a context of other truthful accusations, such as Njord's incest, it is more believable. A

\footnotetext{
${ }^{108}$ W. Bryant Bachman, Jr and Guðmundur Erlingsson (trans). The Sagas of King Half and King Hrolf (Lanham, Maryland: University Press of America, 1991).

Guðni Jónsson and Bjarni Vilhjálmsson (eds), Fornaldarsögur Norðurlanda (Reykjavík:

Bókaútgáfan Forni: 1943-4). Retrieved from Perseus Collection: Germanic Materials. URL http://www.perseus.tufts.edu/hopper/text.jsp?doc=Perseus:text:2003.02.0018

109 'Adulteros a veris coniugibus corporum parte spoliandos constituit'.
} 
serving maid creates a rumour about an adulterous relationship between Gudrun and Thidrek (Guðrúnarkviða in priðja II, Poetic Edda 203). Gudrun swears they did not do anything except offer each other comfort (Gudrun III III-IV, Poetic Edda 203), but she has to prove her innocence by picking up stones from a scalding cauldron in a trial by ordeal (Gudrun III IX, Poetic Edda 204). This testing definitely comes out of a medieval Christian context, showing the influence of Christianity in the concern about adultery. ${ }^{110}$

\section{Riddarasögur}

On the whole, much more is made of adultery in the imported romances, which are firmly set in a Christian context. Adultery seems to be the only way women can have much autonomy, and the plot of many continental romances revolves around it. ${ }^{111}$

This is particularly true in the various stories of Tristram and Isond, which mainly tell of their love for each other and their ways of hiding it from other people. Although Tristram is given the opportunity to marry Isond, he refuses, both before and after falling in love with her (Tristram and Isodd X 274-277). In a way, he chooses their path of adultery. Their passion is the result of a love potion (Tristram and Isodd X 276-277, Tristram ok Isondar XLVI 118-119). When they are caught in adultery they are banished, but as they are found sleeping together innocently in a cave they are presumed not guilty (Tristram and Isodd XI 280-281, Tristram ok

\footnotetext{
${ }^{110}$ The maid-servant is drowned in a bog for slander, which is more typically Germanic (p. 289, note 204). The trial by ordeal is a test in which God's guidance was expected for the administration of justice (Margaret Kerr et al, 'Cold Water and Hot Iron: Trial by Ordeal in England', Journal of Interdisciplinary History 22.4 (1992): p. 573.)

${ }^{111}$ For example, nearly all the Lais of Marie de France centre around adultery, or desired or supposed adultery.
} 
Isondar with a sword between them LXVI 162-163). ${ }^{112}$ They conceive an elaborate plan to prove Isond's innocence: Tristram dresses as a pilgrim and falls on her, so she can claim that only the pilgrim, aside from the king, ever lay on her (Tristram ok Isondar LVIII 148-149). ${ }^{113}$ A variation is Tristram dressed as a beggar man pulling her from her bogged horse (Tristram and Isodd XII 282-283). Isond's adultery leads her down some dark paths, as she makes her maid Bringven lie with the king instead of herself, as she is not a virgin (Tristram ok Isondar XLVI 120-121, Tristram and Isodd XI 276-277), and later, as she fears Bringven will reveal their secret, Isond orders Bringven's execution but later retracts it (Tristram ok Isondar XLVII-XLVIII 122-125, Tristram and Isodd XI 276-277). The story of Tristram and Isond is a tragic one, as it might easily have been avoided, and their love brings about much unhappiness and their deaths. The plot revolves around their adultery. While the story sympathises with the lovers, their adultery brings much unhappiness, ruining two marriages and presumably weakening the reputation of King Markis. Characters within the story, such as the bishop, do condemn their adultery as they attempt to find them guilty (Tristram ok Isond 146-7).

A story that shows a harsh attitude towards women who commit adultery is told in Mottuls Saga and Skikkjurimur. ${ }^{114}$ A beautiful cloak woven by elfwomen is brought to the court, and the bearer suggests that each of the women try it on, without knowing what it shows (Mottuls IV 12-13). Guinevere tries it first, but it

\footnotetext{
${ }^{112}$ This can be compared to Brynhild and Sigurd sleeping with a sword between them, although in this case they were innocent.

${ }^{113}$ Compare Grettir's Saga where Thorstein, in disguise as a tramp, drops his lover Spes when carrying her across mud, and touches her bare leg. Spes goes on to make a vow that only her husband and the tramp had defiled her (Denton Fox and Hermann Pálsson (trans.), Grettir's Saga (Toronto: University of Toronto Press, 1974) LXXXIX 181-3).

${ }^{114}$ See Ch. 1: Spell-casting.
} 
does not reach her heels (Mottuls VI 14-15, Skikkjurimur III XII 298-299). She is embarrassed, and insists that all of the women try it on (Mottuls VI 16-17). It is a misfit for all the women except one (Mottuls X 26-27, Skikkjurímur III LXIX 310311). The cloak shows their infidelity by the way it leaves gaps (for example, for some it is too short at the front, for others at the back, and in one case it fits an old woman perfectly, except for a hole over 'the goose' (Skikkjurímur III XLIV 304305). ${ }^{115}$ Kay explains to the women that their purity is important to their knights as they risk death in battle for their sakes (Mottuls VI 16-17). The knights decide to find themselves new women (Skikkjurimur III LXXVII 312-313), but there is mention of the fact that the cloak to stay new for a long time, showing little expectation of other faithful women (Mottuls XI 28-29). There is no reflection on the fact that the women needed male partners for their infidelity and that at least some of the knights must also be culpable. As the reactions of Kay and the others knights reveal when confronted with the infidelity of their loved ones, adultery is shameful both for the knights and the women, and it greatly undermines the chivalric ideal.

\section{Trying to stop marital sex}

A few instances occur of a woman trying to prevent, or delay, marital sex. These are usually for good reasons. In Ragnar L, Kraka refuses to sleep with Ragnar until they are married (Ragnar L VI 205). Once married, she tries to put him off for another three nights, saying that otherwise their son will be born boneless. ${ }^{116}$ Ragnar could reasonably think that Kraka was making him wait for no purpose as she had already

\footnotetext{
115 'gásar'.

${ }^{116}$ See $\underline{\text { Ch. 1: Prophecy }}$
} 
made him keep his distance, and because of the lowly status of her foster-parents does not believe that she is foresighted. Ragnar is well within his rights as a husband to expect her to sleep with him, but the outcome shows that she was right and should have been listened to. The birth of Ivar is not a disaster, as he becomes a very powerful man, but he is not the usual type of son a warrior king would desire.

A similar situation occurs in History. Thora, once married, tells her husband that she does not want to sleep with him until she has had an omen that their marriage will be fruitful. ${ }^{117}$ He complies happily enough, dividing their bed with a sword, but he has such a positive dream that very night that she decides there is no reason to abstain any longer, and they consummate their marriage (History IX [2956] 266-7). Thora's husband is perhaps less virile than Ragnar, as he agrees to every request his wife makes of him. However, it turns out well for him, as Thora does not in fact make him abstain and is a good wife.

A third example occurs in Gylfaginning. Skirnir woos the giantess Gerd on Freyr's behalf, and she agrees to marry him in nine days. This timeframe seems to be imposed by Skirnir, rather than Gerd. Freyr is unwilling to wait so long, saying:

'Long is a night, long is a second, how can I suffer for three?

Often has a month seemed shorter to me than half this wedding-eve.'

(Gylfaginning XXXVII, Prose Edda 32) ${ }^{118}$

This further illustrates the dissatisfaction of male characters in a delay of the consummation of their marriage.

\footnotetext{
${ }^{117}$ See Ch. 1: Prophecy.

118 'Löng er nótt, / löng er önnur, / hvé mega ek preyja prjár? / Oft mér mánaðr / minni pótti / en sjá half hýnótt.' Gordon explains that the hýnótt refers to the days before marriage, as well as the three days of abstinence required after the marriage takes place (E.V. Gordon, An Introduction to Old Norse (Oxford, Clarendon Press), p. 198 note 81-84.
} 
A reverse situation occurs in Iven. Luneta pretends to her lady that she has had to summons Ivan from far away, and he will take a few days to arrive in the city. In reality, he is there in hiding all along. Despite her previous reticence, the lady is extremely impatient to meet him, saying that seven nights is too long to wait. Luneta promises to have him there in three nights instead, and the lady sends her off in all haste to accomplish this (Iven V 56-7). This example illustrates the great importance many women in the riddarasögur place on romantic and sexual relationships. They are far less independent than the women of the fornaldarsögur.

\section{Making own marital decisions / Leaving husband/lover}

As I have noted, many of the women in Old Icelandic literature are strong willed, to put it mildly. They are often very independent and act according to their own wishes, although not necessarily in their own interests. Marriage is central to their lives, so it makes sense that they should have opinions on their prospects and be actively involved in the decisions. An unhappy marriage can be a catastrophe, as is especially illustrated in Volsungs. For a woman to leave her husband or lover reflects poorly on the man, so it is better if the suit is well matched.

Some women make their own decisions about marriage, or at least express their opinions. Thornbjorg, the maiden king of Hrolf Gautreksson, tells her father that if someone whom she does not want asks to marry her, it would be better for the kingdom if she made her own answer (Hrolf Gautreksson IV 35). And indeed, all of her suitors suffer for daring to propose to her (Hrolf Gautreksson VI 42). The women of Volsungs are weak in this respect, as Signy, Brynhild and Gudrun (in the 
case of Atli) are unwilling to marry their husbands, but are all coerced into it (Volsungs III 38, [XXIX] XXVII 82, [XXXIV] XXXII 95). Perhaps this is why their stories stand out in their tragedy. Kraka is more assertive, as although she means to marry Ragnar, she does this on her own terms (Ragnar L VI 203). ${ }^{119}$ Sigrun tells Helgi that she will not marry Hodbrodd as her father intends, and she has her way in this, although in two versions with disastrous results, in the death of her family in the first, and the death of Helgi in both (Helgi II XXVI-XXX Poetic Edda 137, Helgi Hi XXXIX Poetic Edda 130). Frothi shows some wise judgement in History when he changes the law so that women can choose their own partners, and can be legally married to men they have not consulted their fathers about (History V [143] 128). By giving women their own authority, undesirable marriages seem more likely to be avoided.

A woman can actively make decisions from within a relationship, especially when she decides to leave a husband or lover. Sometimes this decision is forced by others. It can greatly shame the men, as shown when Brynhild threatens to return to her kin if Gunnar does not kill Sigurd and his son. Gunnar is willing to break his blood oaths to Sigurd in order to keep his wife because it would be a worse dishonour if his wife left him (Volsungs [XXXII] XXX 88-9). In Volund, the swan maidens by their own volition leave their lovers after seven years (Volund III, Poetic Edda 103). Volund stays alone waiting for his lover to return, and this brings about his capture and the ensuing tragedy (Volund V-XI, Poetic Edda 103-4).

\footnotetext{
${ }^{119}$ A different sort of power game is shown in the Ivan sagas, where Ivan's lady love pretends that she does not want to marry Ivan, and makes her courtiers implore her for a long time before she will, although she is actually more willing than they are and will have her way no matter what. (Ivens saga VII 62-63, Haerra 11.1559-1618, 80-83).
} 
Sometimes women are forced to leave their lovers. Ketil's father makes Hrafnhild, Ketil's troll mistress, unwelcome, so she is not willing to stay around (Ketil Trout III). Ring marries Ingibjorg, makes her take off the ring which her lover Frithjof had given her, and gives it away, signalling an end to Frithjof and Ingibjorg's romance (Frithjof VIII 95-6). In History, Gurith is at the point of being forced to marry someone when her betrothed returns and berates her, and when she says she has no choice he kills all the wedding party and gets her as his prize (History VII [224-5] 205-6).

There are also occurrences of women leaving their husbands in mythology. Night, in the Prose Edda, has several husbands, as she marries first Naglfari, then Annar, and finally Delling (Gylfaginnning X, Prose Edda 13-4). No reason is given for her leaving each of them, but sequentiality is implied. The story of Njord and Skadi shows a mutual break up, as neither of them can be happy in the home of the other (Gylfaginning XXIII Prose Edda 23-4). They are both independent deities, and do not rely on each other to perform their divine functions: indeed, as Skadi is a ski goddess, and Njord is god of the sea, their divine functions make them mutually incompatible. This suggests that their break up is the best result in order for them to act as gods, and implies that divorce, among the gods at least, is a possibility.

\section{Seduction}

Women in the fornaldarsögur are assertive, and they know what they want. Normally, it would be expected that the male would be the party to suggest romance, 
marriage, a liaison, or to seduce. This is often the case, but by no means always. Women often take matters into their own hands.

Victims of curses need to be forward in order to free themselves from their curse. As the breaking of the curses usually requires close interaction with a man, often sexual, chastity and prudence must be put aside. In Hrolf Kraki, the elfin woman, made ugly by her stepmother's curse, has to persuade Helgi to share his bed with her. Nonetheless, once she has transformed back to being beautiful, he expects her to remain with him for the night (Hrolf Kraki [XI] XV 22-3). Other occasions of this happening involve trolls, or, more specifically, princesses enchanted into trolls. Thus, in Grim Shaggy-Cheek, the ugly girl that helps Grim refuses to do so unless first he kiss her and then sleep with her. Fortunately, the curse is then broken and she turns back into his considerably more attractive beloved (Grim Shaggy-Cheek II). The situation is similar in Thorstein Vikingsson, where Skellinefja/Ingeborg makes Thorstein promise to marry her before she will heal him (Thorstein Vikingsson XIX 52). In none of these situations does the transformed woman actually require the hero to have sexual intercourse with her; Helgi forces the elf-woman to stay with him, Grim falls asleep as soon as he gets into bed, and it is not said whether Skellinefja/Ingeborg and Thorstein even share a bed. However, each of these unions produces a daughter: the elf-woman and Helgi conceive Skuld, Ingeborg and Thorstein have a daughter, Vefreyja, who was conceived and born in Skellinefja's cave (Thorstein Vikingsson XXV), and Grim and Lofthaena have a daughter, Brynhild, soon after their marriage (Grim Shaggy-Cheek III). Any consequences coming from these unions are the responsibility of the man, not the woman or the 
curse. He chooses to have sex with the women, although only the elf-woman shows any sign of unwillingness.

Some women, however, are dangerous in their forwardness. In Helgi Thorisson, Ingibjorg, the leader of some beautiful women, asks Helgi the formulaic question of whether he would rather sleep with her or alone (Helgi Thorisson I 277). ${ }^{120}$ They sleep together for three nights, and later in the tale for another period, but in the end she sends him back blinded, and he dies within a year (Helgi Thorisson III 280-1). She had decided that she no longer wanted him with her, but did not want anyone else to have him either. Unlike the hideous looking but good trollwives of Grim Shaggy-Cheek, Ketil Trout and Thorstein Vikingsson, she is attractive but lethal.

In Yngvars saga vífförla, seemingly friendly women come to the war camp, and Yngvar warns his men to 'be aware as of a viper'. One woman lies with him, and he stabs her between the legs. Many of his men resist, but those who do not are dead by morning (Yngvar VII 30). ${ }^{121}$

In Helgi Hiorvardsson, Hrimgerd the troll wants to sleep with Helgi as a form of compensation, but he tricks her so that she is exposed to daylight and becomes stone (Helgi Hi XXIV-XXX, Poetic Edda 128-9). She could be a threat if he refused her desired compensation, but he outwits her. Nanna's attraction for Hother when she 'began to seek his embraces' brings him into considerable danger

\footnotetext{
${ }^{120}$ This style of question is found in Grim Shaggy-Cheek II and Ketil Trout III, at the heroes' encounters with troll women.

${ }^{121}$ W. Bryant Bachman, Jr and Guðmundur Erlingsson (trans), Six Old Icelandic Sagas (Lanham, Maryland: University Press of America, 1993). Guðni Jónsson and Bjarni Vilhjálmsson (eds), Fornaldarsögur Norðurlanda (Reykjavík: Bókaútgáfan Forni: 1943-4). Retrieved from Perseus Collection: Germanic Materials. URL http://www.perseus.tufts.edu/hopper/text.jsp?doc=Perseus:text:2003.02.0039
} 
because of Balder's passionate desire for her (History III [69] 63). This is a very different depiction of the deeply-in-love Nanna and Baldr of the Prose Edda (Gylfaginning XLIX, Prose Edda 49). Fortunately Hother is helped to defeat Balder. $^{122}$

Sometimes it is necessary for the woman to be forward to prove that she is interested in the man, and ensure that she is considered as a potential lover. Hading would probably never have considered his giantess nanny Harthgrepa as a lover if she had not offered herself to him (History I [22] 21). The Scottish queen Herminthrud offers herself as a trophy to the already married Amleth, saying that his own wife is not worthy of him (History IV [98-9] 89-90).

In Halfdan Eysteinsson, Ingigerd actually goes to the length of sitting on Halfdan's knee after the battle, and her mother gives herself and her daughter to Halfdan (Halfdan Eysteinsson XX 192, XXIII 195). This must have been unexpected for Halfdan, considering his father had killed Ingigerd's, and she had helped to kill his (Halfdan Eysteinsson III 173, VIII 179). However, the two women make their intentions very clear.

In the story of Svanhvita and Regner, Regner thinks that she is mocking him until she shows her beauty and he falls in love with her (History II [44-5] 41). While she does not exactly give herself to him, she shows her interest by her open admiration of him and by displaying her beauty.

In the riddarasögur, women offer themselves to the heroes on several occasions. In some episodes this is viewed positively, whereas in others it shows the sinfulness and potential danger of the women. There are two examples in Janual.

\footnotetext{
${ }^{122}$ See Ch. 1: Magical Protection.
} 
Presumably in the lacuna the beautiful faery-like woman offers herself and all his desires to Janual (Janual 10-11), ${ }^{123}$ and later Guinevere offers herself to him (Janual 12-13). Guinevere is depicted as a petty and self-centred adulteress, whereas the faery is Janual's salvation.

In the Tristram tales, Blensibly decides she must reveal her love for Kanelangres, although she worries that he will think her promiscuous for doing so (Tristram ok Isondar VII 38-39). Although they are happy for a time, their relationship ends in heartbreak and death (Tristram ok Isondar XV 46-49).

Another example of forwardness is in Parceval, when the maiden who has no knight to fight for her goes to Parceval in the night wearing only her shift. Once he agrees to fight for her, she wants to leave, but he will not allow it. She tells him sin and shame never entered her mind, and indeed, they spend the night 'kissing and embracing with no sin'. It is the next day, with her enemy defeated, that 'they amused themselves in each other's arms' (Parceval VII 132-137). ${ }^{124}$ This is just one of Parceval's many adventures, and if anything reflects on him well compared to some of his other encounters with women.

\section{Fornication}

Fornication, considered here as pre-marital sex, comes up with great frequency, but is rarely dwelt upon. It usually occurs only in one match per woman. Many pairs of lovers do not wait for marriage to consummate their relationship, sometimes because marriage is not an option (viz, Bera and Bjorn in Hrolf Kraki [XX] XXVI 37;

\footnotetext{
${ }^{123}$ Marianne E. Kalinke (ed.). Norse Romance. Vol. 1: The Tristan Legend. Cambridge: D.S. Brewer, 1999.

124 'Með kossum ok halsföngum... var án alla synd' ; 'Skemta pau sér par hvárt í annars faðmi’.
} 
Frithjof and Ingibjorg in Fridthjof IV 82; Oddrun and Gunnar Oddrun XX, Poetic Edda 207; Hagbarth and Signe History VII [214-5] 194-6). It is not uncommon for such alliances to result in pregnancy: Bera becomes pregnant with triplets (Hrolf Kraki [XX] XXVII 40), Ingeborg, still in troll form, becomes pregnant in Skellinefja's cave (Thorstein Vikingsson XXV 73), Bodvild, either raped or seduced, is pregnant when Volund leaves (Volund XXXVI, Poetic Edda 107), and Regner makes a girl pregnant when he disguises himself as a woman in order to spend a night with her (History IX [285] 256). ${ }^{125}$ These relationships rarely result in any sort of slur on the woman's name, except sometimes in the opinions of their fathers, as in the last example. The false accusation of fornication between Hithin and Hogin's daughter is intended to be defamatory for Hithin, rather than the girl (History V [149] 133-4).

Occasionally, women are pushed into fornication by their kin. Because of the curse laid on her, Grid has no choice but to suggest that Illugi, and presumably countless others, sleep with her daughter, and it is no wonder that Hild does not show any happiness in bed (Illugi IV 68-9). In Ketil Trout, Bruni gives Ketil the choice of sleeping with his daughter or alone, and he chooses to sleep with Hrafnhild and falls in love with her (Ketil Trout III). Hrafnhild does not get any say in the matter. In a similar situation, Raum in Frá Fornjóti ok hans aettmönnum has a drinking party with Bergfin, the son of the giant Thrym, and Raum goes to bed with

\footnotetext{
${ }^{125} \mathrm{Cf}$ Ch. 2: Adultery:This story adapts from the motif also used in the Tristram sagas and Grettir's saga: the girl proves her innocence by saying none but a maidservant had shared her bed.
} 
Bergfin's sister, Bergdisa (Fornjoti I). ${ }^{126}$ Parents, and male kin, have the ultimate authority over their unmarried daughters.

\section{Promiscuity}

Promiscuity, in this section, is being regarded as a carefree attitude towards casual sexual partners, without concern for morality or consequences.

There are a number of proverbs regarding promiscuous women. Havamal says 'many a good girl when you know her better / is fickle of heart towards men; / I found that out when I tried to seduce / that sagacious woman' (Havamal CII, Poetic Edda 28), ${ }^{127}$ and similarly in Hárbarðsljóð: 'We'd have had wise women, had they been faithful to us... I slept with the seven sisters, / and I got their hearts, and pleasure from them all' (Harbard XVIII, Poetic Edda 72). ${ }^{128}$

Sleeping with a number of sisters is a recurring image, although restricted to the gods. The áss Heimdall is the son of seven sisters (Gylfaginning XXVII, Prose Edda 25), and Thor helps Eaglebeak get revenge on her sisters by sleeping with each of them in turn, so that they kill each other out of jealousy (Egil and Asmund XII 246). These motifs are almost incestuous, although there are no direct sexual relations between kin. How Heimdall is conceived and born is not elaborated on.

\footnotetext{
${ }^{126}$ George L. Hardman (trans.), Of Fjornjot and his Kinsmen. Retrieved from Northvegr Foundation. URL: http://www.northvegr.org/lore/oldheathen/073.php Guðni Jónsson and Bjarni Vilhjálmsson (eds), Fornaldarsögur Norðurlanda (Reykjavík: Bókaútgáfan Forni: 1943-4). Retrieved from Perseus Collection: Germanic Materials. URL http://www.perseus.tufts.edu/hopper/text.jsp?doc=Perseus:text:2003.02.0011 This translation says that 'they' went to bed with Bergdisa, although the verb is the singular ' $g e k k$ '. 127 'Mörg er góð mær, / ef görva kannar, / hugbrigð við hali; / pá ek pat reynda, / er it ráðspaka / teygða ek á flærðir fljóð’.

128 'Horskar áttu vér konur, /ef oss hollar væri; /... hvílda ek hjá peim systrum sjau, / ok hafða ek geð peira allt ok gaman.'
} 
Freyja, the fertility goddess, is the ultimate in promiscuity. In Lokasenna, Loki accuses her of being everyone's lover (Lokasenna XXX, Poetic Edda 90). By being promiscuous, however, she is performing her function as a fertility goddess. Heimskringla describes her as 'rather fickle' (Ynglings XIII, Heimskringla 15). ${ }^{129}$ In the prologue to Sorli, Freyja agrees to spend a night with each of three dwarves, in order to get a necklace (the Brísinga men) from them. She does not seem to have any qualms about this, other than to try to keep it from her lover, Odin (Sorli I 75). In Hyndluliod, Freyja is riding her transformed lover, Ottar, transformed into a boar. She wants to help him because he worships her, but Hyndla accuses her of promiscuity, recalling that many have thrust themselves up the front of Freyja's skirt (Hyndluliod XLVII, Poetic Edda 259), ${ }^{130}$ emphasising Freyja's reputation.

An episode of promiscuity occurs in History, regarding Odin's wife Frigg. Frigg wants the gold off a statue of Odin so that she can decorate herself in it, and 'subordinating her husband's divine honours to the splendour of her own apparel, Frigg submitted herself to the lust of one of her servants', who gets the gold for her. Saxo says that she was unworthy of being a deified consort, and that she felt no scruples about unchastity, provided that she achieved her desired end (History I [26] 25). ${ }^{131}$ This seems much more in line with descriptions of Freyja than Frigg, who is usually only depicted as the grieving mother of Baldr or wife of Odin (Skaldskaparmal XXVII, Prose Edda 86). However, Davidson points out that Loki accuses Frigg of sleeping with Odin's brothers (Lokasenna XXVI, Poetic Edda 89),

\footnotetext{
129 'Heldr marglynd'.

${ }^{130}$ For Hyndluliod see: http://www.heimskringla.no/wiki/Hyndlulj\%C3\%B3\%C3\%B0

131 'At nihilominus Frigga, cultus sui nitorem divinis mariti honoribus antepotens, uni familiarium se stupro subiecit'.
} 
and as this is also found in Heimskringla it is consistent behaviour for her character (Ynglinga Saga IV, Heimskringla $9 .^{132}$

Loki accuses several other goddesses of promiscuity. He says both Skadi and Sif have been to bed with him (Lokasenna LII, LIV, Poetic Edda 93), and he calls Idunn 'the most man-crazed' and accuses her of embracing her brother's slayer (Lokasenna XVII, Poetic Edda 87). He himself is probably the most promiscuous of all, using sex for any means (and in any form, male or female, animal or human), such as when he goes as a mare to distract the horse Svadilfaeri from its duties for the completion of Asgard (Gylfaginning XLII, Prose Edda 36).

Bosi and Herraud contains several girls whose roles are solely to be promiscuous. Bosi spends a night with each of them, and they all have a great time and make lewd references around an extended metaphor, e.g.

'What do you want to do here?' she said.

'I want to temper my warrior,' said Bosi.

'What sort of warrior's that?' she asked.

'He's still very young and he's never been steeled,' he said, 'but a warrior ought to be hardened early on in life.'

He gave her a gold ring and got into bed beside her. She asked him where the warrior was, and he told her to feel between his legs, but she pulled her hand back and said he could keep his warrior and asked why he was carrying a monster like that on him, as hard as a tree. He told her the warrior would soften in the dark hole, and then she said he could do anything he wanted. So now he set the warrior between her legs. The path before him was rather narrow, and yet he managed to complete his mission.

After that they lay quiet for a while, as long as they pleased, and then the girl asked him if the tempering of the warrior had been a complete success. Bosi asked her in turn whether she felt like tempering him again, and she said she' $\mathrm{d}$ be only too pleased as long as he felt like it.

(Bosi and Herraud VII 210)

${ }^{132}$ Davidson, History II, p. 32, note 43. See Ch. 2: Incest. 
On the next occasion they speak about a 'colt' (Bosi and Herraud XI 217), ${ }^{133}$ and on the third, a 'stump' (Bosi and Herraud XIII 222). ${ }^{134}$ The vivid metaphors highlight the lewdness of the girls and Bosi. In exchange, each girl gives him useful information for their quest. However, the first of these girls does point the people in pursuit of the two heroes along their path (Bosi and Herraud X 216), showing that her interest was only in short term entertainment. These incidents, while in place to amuse, must also be there to emphasise the difference between promiscuous peasant girls and the princess Hleid, highlighting the transgressiveness of one class over another, and the difference between Bosi's pursuit of these girls, and Herraud's pursuit of the princess.

Another example of promiscuity is the Hunnish princess who is overtaken by lust once she has Gotvara's aphrodisiac inside her. The princess' distaste for Frothi before she had taken the potion is obvious, but we are told "every female has a veering mind and shifting aims' and that 'a woman free to be coaxed by smooth, flattering compliments would be easily led and quick to comply' (History V [120] $106) .^{135}$

\section{Wanton behaviour}

Aside from these main categories, there are many other examples of wanton behaviour in the fornaldarsögur and other texts. Troll-women are nearly always described as wearing a shrivelled skin-cloak to her feet in front and very short

\footnotetext{
133 'Fola'.

134 'Stúfa'.

135 'Feminam omnem ut volubilis animi', 'feminæ politioribus blanditiarum delenimentis palpanda, non modo abduci facilis, verum etiam obsequi præceps.'
} 
behind (Thorstein Vikingsson XIX 50), with genitalia 'very plain to see' (Egil and Asmund XI 244). ${ }^{136}$ Trolls in general are more relaxed sexually and are able to approach lovers or make lewd suggestions, ${ }^{137}$ such as when a troll-woman in Ketil Trout tells Ketil that she will stroke his body (Ketil Trout V), and when Grid offers her daughter as a lover (Illugi IV 68). Trolls, and humans transformed into trolls, are not constrained by the same moral limitations as humans, but can act as pleases them.

Sexual insults can be made both by men and women. In Heimskringla, Bera constantly says things along the lines of "happy would be the woman who had Yngve instead of Alf for her husband', and her husband Alf becomes so angry at this slight that he kills his brother Yngve, who also kills him. The blame is put on Bera (Ynglings XXIV, Heimskringla 22). In the flyting match in Volsungs, Sinfjotli accuses Granmar of being a witch on Varinsey who chose him as a husband, then of being a valkyrie at Asgard, and says he later sired nine wolves on him. Granmar in turn accuses him of being gelded by a giant's daughters, while Sinfjotli says Granmar is a mare he rode. To be sexually impotent is an obvious insult, but for a man to be described as the passive partner in a homosexual relationship is worse, and Sinfjotli wins this flyting (Volsungs IX 49). Hrimgerd the trollwife and Atli also flyte with sexual innuendo in Helgi Hi, with her saying that he is gelded, and Atli replying that he will be a stallion for her (Helgi Hi XX-XXIII, Poetic Edda 127).

\footnotetext{
136 'Mátti par sjá viðrlita mikil sköp' (cf. also Ali Flekk V 47 and Illugi IV 68).

${ }^{137}$ See Ch. 2: Seduction.
} 
The virility of a man is the issue for contention in most sexual flyting, although the promiscuity of a woman can also be at issue as in Hyndluliod. ${ }^{138}$

Havamal gives many descriptions of women, mostly derogatory. For example, it says to chat to a girl in darkness and use a girl for kisses (Havamal LXXXII, Poetic Edda 25); 'the bed-talk of a woman...let no man trust' (Havamal LXXXVI-LXXXVIII, Poetic Edda 25-6); ${ }^{139}$ 'such is the love of women, of those with false minds; / it's like driving a horse without spiked shoes over slippery ice' (Havamal XC, Poetic Edda 26). ${ }^{140}$ It also puts things the other way, saying 'the hearts of men are fickle towards women' (Havamal XCI, Poetic Edda 26) ${ }^{141}$ as well as 'many a good girl when you know her better / is fickle of heart towards men' (Havamal CII, Poetic Edda 28). ${ }^{142}$ Men, including Odin, are not paragons of virtue sexually, but the fault far more often is put with the woman, often because it is not seen as a fault in the man. Sexual license with women counteracts their role as loyal wives and daughters, but for men is taken for granted.

Harsh terms can be used when speaking about fickle women. Gram, in History, speaks of Signe making herself:

a token of female frailty.

She entices princes in order to trap them, dishonours them, most of all repudiating the upright; she remains steadfast with none. (History I [21] 19) ${ }^{143}$

\footnotetext{
${ }^{138}$ See Ch. 2: Promiscuity.

139 'brúðar beðmálum... trúi engi maðr'.

140 'Svá er friðr kvenna, / peira er flátt hyggja, / sem aki jó óbryddum / á ísi hálum'.

141 'Brigðr er karla hugr konum'.

142 'Mörg er góð mær, / ef görva kannar, / hugbrigð við hali'.

143 'Femineæ dat levitatis facinus notandum, / quæ proceres illaqueat, pellicit atque fœdat, / ante alios ingenuos præcipue refellens, / nec stabilis permanet ulli'.
} 
An incident that stands out is when Starkather finds Helga, Ingel's sister, being groped by a goldsmith. She is ashamed when they are observed, as he had even asked her to remove the fleas from his groin (History VI [176] 157-8). Starkather hits her in the face, and says 'a woman borne blindly by desire, like a crazy mare, / has sported wretchedly, buried her name in lust'. He tells her she deserves to be sold to grind a millstone 'unless blood squeezed from your nipples / proved you falsely blamed, and a breast empty / of milk cleared you of guilt' (History VI [178] 160). ${ }^{144}$ This is not Starkather's only example of extreme misogynistic language. He speaks of Ingel's wife as 'skittish and wanton, [she] joys to practise Teuton rites, devises orgies and prepares adulterate foods... a pert precocious whore, she feeds her pig of a mate and lets him thrust his penis into her willing buttocks in criminal lust' (History VI [189-90] 173). ${ }^{145}$ Starkather uses this as a way of getting at Ingel, but it inevitably suggests a disgust regarding women's sexuality.

Women can also come across as sexually crude in humorous stories. Loki's way of making Skadi laugh is to tie a cord between the beard of a nanny-goat and his testicles, and squealing go back and forth, before dropping into Skadi's lap (Skaldskaparmal III, Prose Edda 61). This is coarse, but effective.

In Völsa páttr, an old woman preserves a horse's phallus which she and her family worship, before it is thrown to the dog by the visiting King Olaf. The way her household reveres the phallus must be intended to be humorous, despite Olaf's

\footnotetext{
144 'Luserit infelix, quæ cæca libidine fertur / more furentis equæ sepelitque cupidine famam. / Gentibus externis pretio venire mereris digna mola, / ni te falso probet insimulatam / elicitus mammis cruor expurgetque reatum / uber inops lactis.'

145 'Uxor Ingelli levis ac petulca / Theutonum ritus celebrare gestit, / instruit luxus et adulterinas / præparat escas.'... 'Pascit ut porcum petulans maritum, / impudens scortum natibusque fidens / gratis admissum tolerare penem / crimine stupri'.
} 
disapproval of their pagan ways. The bondwoman strokes the volsi, and speaks over it saying:

'For sure I'm not able

To keep from

Thrusting it in me.

If with it we lay -

Fun for both!

$(\text { Volsi 110) })^{146}$

The old woman is dismayed at its loss and is an unwilling convert from paganism to Christianity, making her seem ridiculous (Volsi 105-112). ${ }^{147}$

Another comic moment comes up in Haerra when Ivan thinks that one can quickly change a woman's mind: 'they may say 'no' yet mean 'yes', (Haerra 1.1100 58-59). Immediately after this, Luneta goes on his behalf, and persuades her mistress to accept him, proving his assertion correct (Haerra 60-3). His attitude to women would not work in the fornaldarsögur where women speak their minds, but in the riddarasögur it is appropriate.

\section{Conclusion}

Women's sexuality comes up in many areas of Icelandic literature, and often in ways that could be viewed disfavourably. The attitude towards sexual transgressions is largely dependent on the women involved. Sometimes the opinions of other characters or the narrator are expressed, especially in the riddarasögur and History. In the fornaldarsögur and mythology little judgement is expressed. The way women

\footnotetext{
${ }^{146}$ W. Bryant Bachman, Jr (trans.), Forty Old Icelandic Tales (Lanham, Maryland: University Press of America, 1992). Guðni Jónssson (ed.) Íslendinga sögur (Akureyri, Iceland: Íslendingasagnáutgáfan, 1953). Retrieved from Heimskringla. URL http://www.heimskringla.no/wiki/V\%C3\%B6lsa_\%C3\%BE\%C3\%A1ttr ${ }^{147}$ Motif V1.8.2 Horse worship. Inger Margrethe Boberg, Motif-Index of early Icelandic Literature (Copenhagen: Munksgaard, 1966).
} 
behave sexually reflects their backgrounds: troll-wives and peasant girls are more likely to be promiscuous than queens, but adulterous betrayals by queens have more consequences. On occasion women judge their own actions, and are not happy about what they have done. Although sometimes treated lightly, transgressing sexually can lead to dire consequences. 


\section{Chapter Three: Women in the domain of men}

\section{Introduction}

Women in the fornaldarsögur, the myths, and in Saxo's History are notable for their fiery independence. While there are certainly more timid varieties as well, it is the ones who transgress and act outside their feminine domain or in unanticipated ways who make their mark in the stories. In a heroic society with gender roles clearly divided, the ways of doing this often involve taking on a masculine role. A woman can act as a king, a warrior or a viking, sometimes denying her gender and at other times acknowledging it. She may be dominant over her male kin. Women come to the battlefield in the form of witches, valkyries and of shield-maidens. Sometimes the reverse happens, and men take on the role of women for various purposes. A great deal of scorn appears to be felt for most of these men, but, on the whole, the same is not the case for the women. Below I shall examine several of the different motifs of women taking on masculine roles, or acting within a masculine domain, and the reverse.

\section{Maiden Warrior ${ }^{148}$}

Women in battle are extremely common. They are an important part of Norse mythology, in the form of Freyja, who is entitled to half the dead from any battle, and the valkyries, who bring about Odin's will in battle by choosing the warriors who are to die. Many women in the texts I have looked at actually fight in battle; some figures play quite extensive roles in their respective stories, whereas others are

\footnotetext{
${ }^{148}$ See Jochens pp. 87-112.
} 
more peripheral. The maiden warrior seems to be quite distinctly Scandinavian. The seneschal in the Swedish romance Haerra Ivan says that 'Little defence rests with women, / since they cannot bear arms' (Haerra 11.1583-4, 80-81), ${ }^{149}$ but the Icelandic stories and Saxo's history tell us otherwise. In a few cases, women go back to being warriors, even after being married. In other cases, like Brunhild in Thidrek's Saga, who loses her strength once Siegfried conquers her in bed, their marriage and loss of virginity bring about their loss of warrior prowess. ${ }^{150}$ In a few cases, like Aslaug and Gudrun, their warrior skills are not shown until already married.

Freyja is present as a war-going force, if not as a warrior herself. The Prose Edda tells us that whenever Freyja rides to battle she gets half of the slain (Gylfaginning XXIV, Prose Edda 24). ${ }^{151}$ What Freyja does with the slain is unclear: presumably, like Odin's warriors in Valhalla, they also fight on the side of the gods at Ragnarok.

In Sorli, in order to have the Brísinga men returned to her, she agrees to bring about war between two kings, in which the armies would keep returning to life and fighting until stopped by a Christian who would kill them (Sorli II 76-7). As a deity, she seems untroubled by this; her interest in humans is only in terms of how they can serve her purpose.

The Volsung women are, unsurprisingly, of the warrior type. Brynhild 'wants to go warring and win all kinds of fame' (Volsungs [XXV] XXIV 74). ${ }^{152}$

\footnotetext{
149 'A fruor ligger liten væria, / py at pe kunnæ eigh vapn at bæræ'.

${ }^{150}$ George K. Anderson, (trans.), The Saga of the Volsungs, together with excerpts from the Nornageststhattr and three chapters from the Prose Edda (Newark: University of Delaware Press, 1982), p. 214.

${ }^{151}$ Odin gets the other half of the slain.

${ }^{152}$ See further in Ch. 3: Valkyrie.

XXIV 'Hún vill sik í herskap hafa ok alls konar frægð at fremja'.
} 
Brynhild also claims in Sigurðarkviða in skamma that she had considered killing Atli in battle, as he would not give her inheritance to her until she was betrothed (Sigurd sk XXXVI-XXXVII, Poetic Edda 187). Fighting, and being in battle, is part of her nature. This is not the case for Gudrun, who only fights on one occasion, when she takes up mail and a sword with her brothers against Atli (Atlamal XLIX LI, Poetic Edda 224). Atli calls her a 'monstrous wife' (Atlamal LVI, Poetic Edda 225). ${ }^{153}$ Gudrun acts this way reacting to circumstances, rather than because it is her nature. This warring tradition continues in the next generation, as Aslaug, Sigurd and Brynhild's daughter, takes up arms and wears armour, and travels overland as the commander of an army of fifteen hundred (Ragnarssons II). Initially in Ragnar L she wants to travel with the ships, but her son Ivar the Boneless tells her to lead the ones marching by land. As she does not normally acquiesce to men against her will, it is somewhat surprising that she agrees. She is renamed Randalin (Ragnar L XI 225-6).

Hervor, in Heidrek, is a very striking figure of a female warrior. She is, of course, very beautiful, and as strong as a man. She trains herself with weapons, and creates trouble, becoming a bandit (Heidrek III 10). When she finds out who her father is, she plans to seek him out for his wealth and tells her mother to equip her as she would a son (Heidrek III 11-12). She joins some vikings, using the male name Hervard. Soon she becomes their captain, and decides, against the wishes of her crew, to disembark on Samsey, where her father and his brothers are buried (Heidrek III 12). Although nobody will stay with her on the island, she is unafraid, and tells Angantyr to wake from the dead and give her his sword Tyrfing (Heidrek III 14).

153 'Kona váliga'. 
She does not care when he says it will ruin her family (Heidrek III 16). He says he knows no woman who would dare hold the sword, but she says she will, without fear, and he gives it to her (Heidrek III 17-18). ${ }^{154}$ With the sword, she travels on to Gudmund of Glasisvellir, still calling herself Hervard and behaving like a warrior. When a man draws Tyrfing she snatches it and strikes off his head. Gudmund advises his men not to go for revenge, partly through fear of the sword, and partly as he suspects that she is a woman and there would be little glory to be gained (Heidrek IV 20). This gives little credit to Hervor's prowess as a warrior. She joins some vikings again and goes raiding for a while, and when she tires of this she goes to Bjalmar the jarl, and settles down to fine work and gets married (Heidrek IV 20). This is the end of her career as a warrior.

The change from an incredibly determined and heartless woman, prepared to sacrifice her descendants, to a bored woman who settles to fine work, seems extraordinary, and yet is not unusual in these sagas, as further examples in this chapter show. The poem, The Waking of Angantyr, is older than the saga it is slotted into, ${ }^{155}$ which could explain why Hervor is allowed to drop out of the saga so quickly afterwards. Her granddaughter, also called Hervor, is a warrior woman as well (Heidrek VIII 30). She has a stronghold to defend her land against the Huns. She leads her army out, but the Huns are so many that she falls, and the rest flee (Heidrek X 53). Her trumpeter speaks of her to Angantyr as:

in war more happy than in wooer's converse or at bridal banquet

\footnotetext{
${ }^{154}$ See Ch 1: Interaction with the dead

155 Jochens p. 98.
} 
on bench to seat her.

$\left(\right.$ Heidrek X 54) ${ }^{156}$

Unlike the original Hervor, her early death means that she does not have a chance to change her ways, had she wanted to.

Thornbjorg of Hrolf Gautreksson is both maiden-warrior and maiden-king. She is better at feminine arts than other women, and as good as a knight with weapons (Hrolf Gautreksson IV 34-5). She is her father's only heir, and so believes that she needs to have the skills to defend his kingdom. She also wants to be able to fight so that she does not have to marry anyone against her will (Hrolf Gautreksson IV 35). Having been granted a third of her father's kingdom, she becomes more arrogant, responding only when addressed as a man. ${ }^{157}$ When Hrolf comes courting she fights and ends up chasing him away (Hrolf Gautreksson IX 54). When Hrolf returns she insults him again, and the two sides battle. Hrolf says not to use weapons against her, but when Ketil takes her captive he strikes her, with sexual innuendo, and she strikes him in return, calling him a dog (Hrolf Gautreksson XIII 66). Once she is defeated, Thornbjorg seeks her father's judgement. She lays down her weapons and goes to her mother's room, and agrees to marry Hrolf (Hrolf Gautreksson XIII 68). Towards the end of the saga, Thornbjorg again takes up her sword and shield, and her son, to search for Hrolf when he is absent. She commands the whole army (Hrolf Gautreksson XXXI 133). ${ }^{158}$ When they are reunited, Hrolf meets Thornbjorg at the front of the troop (Hrolf Gautreksson XXXV 142).

\footnotetext{
156 'Léttari gerðist hún at böð / en við biðil ræða / eða í bekk at fara / at brúðar gangi.'

${ }^{157}$ Sometimes even the narrator uses 'he' when talking about King Thorberg (Thornbjorg), and Hrolf treats her as masculine when they first meet, calling her 'herra' (Hrolf Gautreksson IX).

${ }^{158}$ However, Ketil burns all the houses in Ireland although this is against Thornbjorg's wishes, showing that like Hrolf, her power is not absolute (XXXIV 140).
} 
Obviously the warrior instinct never entirely leaves her, although she is able to put it aside until she deems it is necessary in her role as a wife and queen.

There are other more minor female warriors in the fornaldarsögur. ${ }^{159}$ They are not particularly effective, and are never developed as characters aside from a brief description of a few pertinent characteristics. Only female warriors central to the stories are shown to be good warriors. In Arrow-Odd's Saga a skjaldmaer is given to Odd to act as a shield for him. However, Odd tests her, and as she proves to be more fearful than he is he leaves her behind (Arrow-Odd XXVIII 110). ${ }^{160}$ This reflects on Odd's prowess, as the king who lent the skjaldmar to him had been saved by her many times. In Bosi and Herraud, Brynhild the skjaldmaer marries Thvari. He had earlier defeated her in battle, and healed her wounds, but she could no longer fight and 'remained bent and twisted for life', and because of this is called 'StuntBrynhild'. Their marriage is happy, although she wears armour to the wedding. She is only a background figure in the story of her son and his friend, and we are told that she was particularly fond of her younger son, Bosi, who took after her in personality and looks. (Bosi and Herraud II 200).

Both of these sagas with skjaldmeyjar also include fighting priestesses. Bosi and Herraud have to work together to be able to kill the priestess Kolfrosta as she is so fierce (Bosi and Herraud VIII 213). In Arrow-Odd, the priestess shoots arrows from all of her fingers (Arrow-Odd XXIX 113). Both of these priestesses are also

\footnotetext{
${ }^{159}$ skjaldmaer - translated as 'amazon' by both Pálsson and Edwards and Geir T. Zoëga's A Concise Dictionary of Old Icelandic (Oxford: Clarendon Press, 1961). Retrieved from Northvegr Foundation. URL http://www.northvegr.org/zoega/index002.php

Pálsson and Edwards also use 'Amazon' as a chapter title in Hrolf Gautreksson (p. 34). Jochens speaks of skjaldmeyjar when speaking about heroic 'valkyrie' figures, but it is also the usual term for maiden warriors (p. 95).

${ }^{160}$ For Arrow-Odd see: http://www.perseus.tufts.edu/hopper/text.jsp?doc=Perseus:text:2003.02.0028
} 
called 'ogress' in translation. ${ }^{161}$ They are far more fearsome than the experienced

fighting skjaldmeyjar, perhaps because of their skills in magic. ${ }^{162}$

\section{History of the Danes}

Saxo makes the most extensive use of the idea of the woman warrior, as his work encompasses so many stories, and spans so many generations. Again, some of the stories are more detailed and more fabulous than others. Saxo writes a paragraph about the history of women warriors:

In case anyone is marvelling that this sex should have sweated in warfare, let me digress briefly to explain the character and behaviour of such females. There were once women in Denmark who dressed themselves to look like men and spent almost every minute cultivating soldiers' skills; they did not want the sinews of their valour to lose tautness and be infected by selfindulgence. Loathing a dainty style of living, they would harden body and mind with toil and endurance, rejecting the fickle pliancy of girls and compelling their womanish spirits to act with a virile ruthlessness. They courted military celebrity so earnestly that you would have guessed they had unsexed themselves. Those especially who had forceful personalities or were tall and elegant embarked on this way of life. As if they were forgetful of their true selves they put toughness before allure, aimed at conflicts instead of kisses, tasted blood, not lips, sought the clash of arms rather than the arm's embrace, fitted to weapons hands which should have been weaving, desired not the couch but the kill, and those they could have appeased with looks they attacked with lances.

(History VII [212] 192) ${ }^{163}$

\footnotetext{
161 'Gýginni’ Arrow-Odd XXIX 116 from gýgr, meaning giantess or hag (Zoëga); ‘tröllkona' Bosi and Herraud VIII 213 'troll-woman'.

${ }^{162}$ See Ch. 1: Magic in battle.

163 'Et ne quis hunc bellis sexum insudasse miretur, quædam de talium feminarum condicione et moribus compendio modicæ digressionis expediam. Fuere quondam apud Danos feminæ, quæ formam suam in virilem habitum convertentes omnia pæne temporum momenta ad excolendam militiam conferebant, ne virtutis nervos luxuriæ contagione hebetari paterentur. Siquidem delicatum vivendi genus perosæ corpus animumque patientia ac labore durare solebant totamque femineæ levitatis mollitiem abdicantes muliebre ingenium virili uti sævitia cogebant. Sed et tanta cura rei militaris notitiam captabant, ut feminas exuisse quivis putaret. Præcipue vero, quibus aut ingenii vigor aut decora corporum proceritas erat, id vitæ genus incedere consueverant. Hæ ergo, perinde ac nativæ condicionis immemores rigoremque blanditiis anteferentes, bella pro basiis intentabant sanguinemque, non oscula delibantes armorum potius quam amorum officia frequentabant manusque,
} 
These women are literary images, and Saxo probably does not expect them to be understood as literal figures. Women warriors, in Saxo's text, can be split between those who are warriors by nature and those who try the warrior lifestyle for a time.

Some warrior women are part of a longer tale, of which their warrior episode is only a part. Gunvara only shows warrior behaviour on one occasion, when she and Erik both kill an attacker, with her 'matching a man's spirit though her body was a woman's' (History V [140] 125). ${ }^{164}$ Gurith, like Aslaug and some of the others above, dresses as a man and goes to war for the sake of her son, and she sees her husband Haldan die. She carries her son away on her shoulders when his comrades flee. He considers this more shame than help as he gets an arrow in his bottom (History VII [225] 206). Still, the fact that he survives shows the importance of women in battle, and not just as warriors.

Alvild also only takes up the warrior lifestyle for a time. She is married to Alf, but her mother abuses her for this, saying that she is only attracted to Alf for his appearances. The previously feminine Alvild puts on men's clothing and becomes a pirate. Many other girls join her, and she later becomes pirate chief over a group of male pirates, and performs 'feats beyond a woman's courage'. Interestingly, she is appointed as their leader due to her beauty, suggesting that it is partly her femininity that makes her both a good leader and a good warrior. When Alf pursues her, she attacks him. On board her ship one of his men strikes off her helmet and realises 'they ought not to be fighting with weapons but kisses'. When she is conquered, Alf

quas in telas aptare debuerant, telorum obsequiis exhibebant, ut iam non lecto, sed leto studentes spiculis appeterent, quos mulcere specie potuissent.'

164 'Muliebri corpore virilem animum æquans.' 
makes her change back into feminine clothes and they have a daughter (History VII [211-2] 191-2). ${ }^{165}$ She never takes up arms again.

It is not uncommon to come upon women who are warriors by nature in Saxo's History. For example, Orvendil ‘hounded down and slew Koller's sister Sela, a warring amazon and accomplished pirate herself' (History III [83] 77). ${ }^{166}$ Hvirvil defeats the warrior woman Rusila, and 'collected manly fame from his female adversary' (History IV [110] 102). ${ }^{167}$ When King Harald Hyldetan hears of a struggle for a kingdom between King Olaf and two women, Stikla and Rusila, he is 'utterly enraged at such female brashness', and attacks them. Once he has defeated them, he names harbours after them, showing some acknowledgement of their prowess (History VII [227] 208). ${ }^{168}$

Many of these warrior women are also rulers, or aspire to be, and fit into the following section, Maiden King. Hetha and Visna 'whose female bodies Nature had endowed with manly courage' lead troops of Slavs to battle. Visna is a very skilled and tough warrior (History VIII [238] 214). ${ }^{169}$ The two women 'graceful in battlegear' lead their land forces to combat (History VIII [239] 215). ${ }^{170}$ Bruni constructs a battle-line with Hetha on the right flank and Visna as standard-bearer (History VIII [241] 218). Starkather later claims to have sheared off Visna's right hand, which is a point of triumph for him among his many other victories in battle, showing that to

\footnotetext{
165 'Maiores muliebri virtute res edidit'... 'animadvertit osculis, non armis agendum esse'.

166 'Deinde sororem eius, Selam nomine, piraticis exercitam rebus ac bellici peritam muneris, persecutus occidit'

167 'Virilemque gloriam ex muliebri hoste corripuit'.

168 'Feminea admodum præsumptione permotus'.

169 'Quarum muliebri corpori natura virilem animum erogavit'.

170 'Pugnaciter cultæ'.
} 
overcome a maiden warrior is a higher sign of ability than to defeat a male warrior, or perhaps that he himself particularly despises maiden warriors (History VIII [242] 219). ${ }^{171}$ The Sjaellanders are not happy to be ruled by Hetha, as she is a woman, and they ask Oli to take them. He orders Hetha to come to him and forces her to withdraw from all areas but Jutland. Jutland he makes a tributary state 'to ensure that a woman was not given a free hand over that realm'. The Sjaellanders later regret their choice, due to Oli's cruelty (History VIII [244] 220-1). ${ }^{172}$ Saxo shows respect for Hetha by suggesting that she would have been a better ruler, even though she was a woman.

The maiden Rusila, 'surpassing a woman's temperament in her strenuous military activities', clashes frequently with her brother for the throne of Norway. She declares war on all who give their allegiance to the Danes, and defeats Onund's army. Proud and arrogant due to her victory, she aims for the sovereignty of Denmark. When she is defeated, she escapes on foot alone, then defeats her brother, 'turning flight into triumph'. She is expelled from Norway by the commoners, and her brother pursues her until he overcomes her. He receives governorship as a reward for this (History VIII [246] 222-3). ${ }^{173}$

Lathgertha is a warrior woman with 'a man's temper in a girl's body'; she battles at the front of the best warriors. Regner admits that his victory is due to her alone. She is a suitable match for him as she is of distinguished rank, and he begins to woo her. She pretends to acquiesce, but once he is confident, she sets a bear and

\footnotetext{
171 'Abscissamque Wisnæ dexteram'.

172 'Ne feminæ liberum regni usum tribueret'.

173 'Strenuis militiæ operibus muliebrem animum supergressa'...' fugam victoria mutavit'.
} 
hound against him (History IX [280] 251). ${ }^{174}$ He overcomes them and wins her. He later divorces her, saying she was not trustworthy, as she had set the animals against him (History IX [281] 252). Considering he knew this when he married her, this seems to be an excuse for remarrying, rather than a genuine reason. Later on, when Regner asks for her help against his enemies, Lathgertha 'in whose veins there still ran strong feelings of her former love', comes quickly with her son and second husband. She provides him with a hundred and twenty vessels (History IX [282] 253). ${ }^{175}$ She encourages the soldiers with her bravery and causes the enemy to panic. Returning to battle brings back her former ways, and in the night she stabs her husband's throat with a dart. She seizes the whole title and sovereignty, as she prefers to govern alone than share the rule with her husband. Lathgertha has a forceful personality, but it is her love for Regner as much as her pride and independence that drives her (History IX [283] 254).

\section{Maiden King (Meykongr)}

The figure of the meykongr comes up with considerable frequency in the fornaldarsögur, as well as in History. As seen above, it is often closely associated with the maiden warrior, as is natural in a society of warrior kings. ${ }^{176}$ The maiden kings are called meykongr, kongr or occasionally drottning.

There are several different sorts of female rulers. There are the mothers, sisters, widows and daughters who take over their son's, brother's, husband's or

\footnotetext{
174 'Virilem in virgine animum gerens'.

175 'Pristini amoris pertinaciore haustu exuberans'.

${ }^{176}$ For an extended discussion of the meykongr in the fornaldarsögur, see Marianne E. Kalinke, Bridal-Quest Romance in Medieval Iceland (Ithaca: Cornell University Press, 1995), chapter III.
} 
father's kingdom; women who rule until they find someone else to whom they wish to give the reigning power; but the most distinctive group of women are those who actively seize ruling power, and are determined not to lose it. There are also the rare cases of women who are awarded a kingdom because they are considered the best candidate to rule.

There are a number of cases of a woman taking over the kingdom of a close kinsman. These are seldom long stories. In a rare instance in which a woman is mentioned in Fornjoti, Queen Margreta, King Olaf's mother, is made sovereign over Norway and Denmark when Olaf disappears (Fornjoti IX). In Af Upplendinga konungum, Asa the Ambitious travels with her baby son, and takes over the kingdom that her slain father, Harald Redbeard, had held (Upplendings II). ${ }^{177}$ In History, Thyra tells Gorm she will only marry him if she receives Denmark as her wedding present, and he grants this wish (History IX [295] 266). In the most detailed story of this type, again in History, Asmund is 'robbed' of his kingdom by his elder sister. With Harald's help Asmund is restored, and his sister is defeated (History VII [226] 207). ${ }^{178}$ This sort of event also comes up in the riddarasögur in the Ivan sagas, when one woman tries to rob her sister of her share of their father's kingdom (Haerra 188277, Iven XIV 90-91). Here, however, it is a dispute between two women, one innocent and the other malicious, rather than a dispute between a presumptuous woman and her male kinsman. Women in these stories are usually very forceful.

\footnotetext{
${ }^{177}$ Gavin Chappell (trans.), Of the Kings of the Uplands. Retrieved from Northvegr Foundation. URL http://www.northvegr.org/lore/oldheathen/016.php Guðni Jónsson and Bjarni Vilhjálmsson (eds), Fornaldarsögur Norðurlanda (Reykjavík: Bókaútgáfan Forni: 1943-4). Retrieved from Perseus Collection: Germanic Materials. URL http://www.perseus.tufts.edu/hopper/text.jsp?doc=Perseus:text:2003.02.0006

178 'Regno spoliatum' lit 'with the kingdom robbed'.
} 
Silkisif, in Yngvar, is an independent ruler. We are not told how the kingdom came to be under her command. Unlike most of the meykóngar she shows no aversion to men, and is not protective of her independence. She is willing to be converted to Christianity, and when she falls in love with Yngvar she offers him herself and her kingdom (Yngvar V 25). ${ }^{179}$ When only his body returns she is distraught (Yngvar VII 31), but before long is happy to marry his son instead (Yngvar XII 36). Silkisif's main 'transgression' is that she is a pagan. Aside from this, she is almost a model female ruler, who brings good to her kingdom through the introduction of Christianity and her active pursuit of a husband in order to put her kingdom in the hands of a male ruler. She is more than willing to pass on her authority.

The figure of the maiden king is an impressive one, but sadly these women are nearly all conquered by their suitors, and fade into the background of the story, sometimes returning to the fore in the concluding episode. Their role as the prize of a bridal-quest romance is unique to Iceland, ${ }^{180}$ the point of which is to show the prowess of the hero by their conquest. This is the case with Thornbjorg of Hrolf Gautreksson. ${ }^{181}$ The purpose of the story about her is to laud Hrolf. Where many other suitors have failed, he is successful, due to his cunning and his skills in fighting.

Another maiden king is Olof in Hrolf Kraki. She tells Helgi she does not want to marry him, but when he says she must she pretends to agree. When he gets

\footnotetext{
${ }^{179}$ For Yngvar see: http://www.perseus.tufts.edu/hopper/text.jsp?doc=Perseus:text:2003.02.0039

${ }^{180}$ Marianne E. Kalinke, Bridal-Quest Romance in Medieval Iceland (Ithaca : Cornell University Press, 1990), p. 103.

${ }^{181}$ Ch. 3: Maiden Warrior.
} 
drunk she sticks him with a sleep thorn, then shaves and tars him, and packs him in a bag for his crew (Hrolf Kraki [VI] VII 12). He takes revenge, coming back and raping her, and casts her aside when he is finished with her (Hrolf Kraki [VII] VIII 15). Olof has the last word, years later, by revealing his incest with their daughter Yrsa (Hrolf Kraki [X] XIII 20). This is not a case where the maiden king is successfully wooed to the triumph of the hero, but one which leads to his great shame. $^{182}$

Ali, in The Saga of Ali Flekk, comes across a more peaceful maiden king, Thornbjarg. When she loses the commander of her army she asks for another one, and promises herself in marriage to the one who would take it up, who happens to be Ali (under the pseudonym Stutthedin) (Ali Flekk VII 49). She sticks with him through terrible curses when everyone else leaves, and in the end she brings about his cure (Ali Flekk XV 56). ${ }^{183}$ Thornbjarg is not the stereotypical image of an egocentric maiden-king, but is a positive image of a good wife, and sensible monarch (at least, until she leaves her kingdom for ten years). Like Silkisif in Yngvar she is responsible to her kingdom by making sure that she marries a hero to defend it.

Blenzibly, in Tristram and Isodd, shows that the motif of the maiden-king is not limited to the fornaldarsögur. She is displeased when she is not considered for her father's succession, and gathers an army without her brother, the king's, permission (Tristram and Isodd II 245). When the king and her army commander

\footnotetext{
${ }^{182}$ Ch. 2: Incest.

${ }^{183}$ Ch. 1: Curses.
} 
joust, her brother wins and the two sides are reconciled (Tristram and Isodd II 247). Blenzibly then takes on the role of a lover and speaks no more of ruling or battle. ${ }^{184}$

In History, the King of Britain sends Amleth to woo a Scottish queen for him, from whom no wooer had ever escaped with his head. She is 'cruelly arrogant' (History IV [97] 88). ${ }^{185}$ She edits his letter so that it suggests that she marry the messenger, as she wants to marry someone younger than the king. She uses information that she learnt from his shield to gives substance to the letter (History IV [98] 89). This queen is able to get around the wooer by cleverness rather than physical strength. Amleth is a more suitable match for her, as the King of Britain did not even have the courage to woo her in person. ${ }^{186}$

On a rare occasion, a woman is designated ruler by men. In Asmund, the sister is the smartest of the Dukes of Saxland, among whom she is counted, so she is appointed their leader. Unlike many of the male and other female rulers, she can make rational decisions not based on pride, saying, for example, that it is better to pay tribute to Hildibrand for a time, and to fight only when they are stronger (Asmund IV 90-1). In the Prose Edda, Odin throws Hel into Niflheim and gives her authority over nine worlds, so that she has to 'administer board and lodging' for those sent to her, namely those who die of sickness or old age (Gylfaginning XXXIV, Prose Edda 27). ${ }^{187}$ For Odin, this is a way to solve a problem, and to get rid of one of Loki's children. Hel fares relatively well compared to Fenrir, who is chained up, and the Jormungard serpent, who is cast into the sea (Gylfaginning

\footnotetext{
${ }^{184}$ See Ch. 2: Fornication.

185 'Insolentia atrocem'.

${ }^{186}$ See Ch. 2: Seduction.

187 'Hon skyldi skipta öllum vistum með peim'. See Ch 4: General Death.
} 
XXXIV, Prose Edda 27). Nonetheless, while she is a ruler, she is definitely a ruler in exile.

\section{Valkyrie}

Valkyries and shield-maidens are discussed in detail in Jenny Jochens' Old Norse Images of Women. Jochens, like Carolyne Larrington in The Poetic Edda, divides them into two groups, namely as Odinic, mythological valkyries on the one hand, who serve mead to dead warriors in Valhalla and fulfil Odin's will in battle by making sure that victory goes to the right man, and shield-maidens on the other hand, who are human and usually fall in love with the hero, ensure victory, and marry. ${ }^{188}$ This usually ends in disaster, despite the strength of the love. There is a certain amount of overlap between these two groups, especially with figures such as Brynhild who is initially very clearly associated with Odin, but later is primarily a human lover.

Brynhild appears to be made of several conflated figures. In Sigrdrífumál, Sigurd first encounters the shieldmaiden Sigrdrifa, an Odinic valkyrie, who teaches him wisdom (Sigrdrifumal, Poetic Edda 166-73). This had been predicted in Gripisspa: 'The prince's daughter, bright in her mail-shirt, / sleeps on the mountain after the killing of Helgi... / you must... / cut the mail shirt' (Gripisspa XV, Poetic Edda 145). She will teach him powerful runes, how to speak every human tongue, and medicine (Gripisspa XVII, Poetic Edda 145). In this version, through its reference to Helgi (Gripisspa XV, Poetic Edda 145), she is linked to Sigrun rather

\footnotetext{
${ }^{188}$ Jochens, pp. 38-9, 90-6.
} 
than to Brynhild. ${ }^{189}$ Sigurd will forsake all for Brynhild. In Fáfnismál, we are told that Sigrdrifa rebelled by bringing down a different warrior from whom Odin had wanted, which is the reason she is made to sleep on the mountain top (Fafnismal XLIII, Poetic Edda 164). This is reiterated in Sigrdrifumal, where she also gives Sigurd a memory drink to retain his new knowledge (Sigrdrifumal V, Poetic Edda 167).

Brynhild appears separately to Sigrdrifa in the poems of The Poetic Edda. Most of her story is missing in the lacuna, as is the end of the Sigrdrifa story. It picks up again with Brynhild bringing about Sigurd's death, and Gudrun lamenting it (Sigurðarkviða in meiri, Poetic Edda 174-6). Little is said about Brynhild's valkyrie role, although in Brynhild's Hellride Brynhild seems to make a reference to being a swan-maiden (Brynhild VI, Poetic Edda 193), and in Oddrun's Lament Oddrun says their father had wished that Brynhild should be a valkyrie (Oddrun XVI, Poetic Edda 207). ${ }^{190}$

In both Volsungs and in the Prose Edda, as well as in Nornageststhattr, Sigrdrifa and Brynhild are merged. In the Prose Edda Sigurd merely removes Brynhild's armour and wakes her, before riding on to the Gjuki and his family (Skaldskaparmal XLVIII, Prose Edda 102). In Volsungs, Sigurd finds a 'man' asleep on a mountain. When he takes off the helmet he discovers it is a woman, and the armour is so tight it has grown into her skin. He cuts it off, saying she has slept too long; Brynhild knows who he is. Like Sigrdrifa, Odin had made her sleep as punishment. Odin decreed that she must marry, but she in turn vowed that she would

\footnotetext{
${ }^{189}$ Larrington p. 282, note 145.

${ }^{190}$ Larrington pp. 288-9, notes.
} 
only marry a man who knew no fear. She teaches Sigurd, and they become betrothed (Volsungs [XXII] XXI 71-2). ${ }^{191}$ Following this scene, but only in Volsungs, Sigurd rides on the Heimir's hall where he encounters Brynhild, as though for the first time. She is called Brynhild because she 'took up helmet and mail coat and went to battle' (Volsungs [XXIV] XXIII 73). ${ }^{192}$ When she returns and embroiders his deeds, he falls in love with her (Volsungs [XXV] XXIV 74). She says 'It is not fated that we should live together. I am a shield-maiden. I wear a helmet and ride with the warrior kings. I must support them, and I am not averse to fighting.' When he argues, she goes on: 'I must review the troops of warriors, and you will marry Gudrun'. Nonetheless they swear oaths to each other (Volsungs [XXV] XXIV 75). ${ }^{193}$ These two scenes between Sigurd and Brynhild do not sit comfortably together, as the latter ignores the first. The author seems to have been uncertain on how to merge the two stories, or did not know which out of the conflicting traditions he should choose. Sigurd's next encounter with Brynhild, in both texts, is when he rides through the flickering flame and woos her on Gunnar's behalf, changing shapes with Gunnar and exchanging rings with Brynhild, although lying chastely beside her (Volsungs [XXIX] XXVII 80-81 ; Skaldskaparmal XLVIII, Prose Edda 102). Sigrdrifa, the rune-teaching valkyrie, and Brynhild, the shield-maiden, are conflated. Conflation continues with further retellings of the story, such as Wagner's, in which Brynhild is the valkyrie who is meant to make Sigemund lose, comparable to the spaewoman in Volsungs who shields Sigmund until Odin comes and breaks his sword (Volsungs XI 53).

\footnotetext{
${ }^{191}$ See Ch. 1: Knowledge/Teaching of Magic.

192 'Brynhildr fór með hjálm ok brynju ok gekk at vígum'.

193 'Eigi er pat skipat, at vit búim saman. Ek em skjaldmær, ok á ek með herkonungum hjálm, ok peim mun ek at liði verða, ok ekki er mér leitt at berjast', 'Ek mun kanna lið hermanna, en pú munt eiga Guðrúnu Gjúkadóttur'.
} 
The other shield-maiden figure who recurs with some frequency is Sigrun/Svava. There are three poems telling the story of her and Helgi in the Poetic Edda. She always helps Helgi win a battle, and they marry. She is human and there are family conflicts, and she needs Helgi to fight off an unwanted suitor, although she helps from the air. In one version he is killed by her brother, in another by the suitor. Only in one poem is he still alive at the end.

In The First Poem of Helgi Hundinsbani a group of valkyries descends on the hero Helgi, and from amongst them Sigrun tells Helgi that she will not marry Hodbrodd as her father intends, and asks him to fight on her behalf (Helgi I XVIIXX, Poetic Edda 116-7). In the ensuing battle, she protects them from above (Helgi I XXX, Poetic Edda 118). She is described as a 'wound-giving valkyrie' (Helgi I LIV, Poetic Edda 121), who gives herself to Helgi. This poem ends with Helgi winning the battle and Sigrun (Helgi I LVI, Poetic Edda 122).

The following poem, The Poem of Helgi Hiorvardsson, is similar, despite the different names. The valkyrie this time is called Svava. She names Helgi, and tells him to talk to her (Helgi Hi VI, Poetic Edda 125). When Helgi dies, he gives her to his brother Hedin (Helgi Hi XLI, Poetic Edda 131), and Hedin swears vengeance for his death (Helgi Hi XLIII, Poetic Edda 131). The poem states that Svava and Helgi are reincarnated (Helgi Hi, Poetic Edda 131).

In the final poem, The Second Poem of Helgi Hundingsbani, the valkyrie Sigrun is said to be Svava reincarnated (Helgi II, Poetic Edda 133). Sigrun is betrothed to Hodbrodd, as in the first poem, but she flies to Helgi and kisses him, as 
she says she had loved him before she saw him. She fears the anger of her kinsmen as she is breaking her father's word, but Helgi is not afraid of her family (Helgi II XIV-XVI, Poetic Edda 135). The battle is a mixed success, as although Hodbrodd dies, Helgi kills Sigrun's father and brother, and other kinsmen (Helgi II XXVXXVIII, Poetic Edda 137). Sigrun and Helgi marry, but Sigrun's other brother kills Helgi (with Odin's help) (Helgi II, Poetic Edda 137). Sigrun visits Helgi in his burial mound, and soon dies of grief. ${ }^{194}$ This poem also concludes by saying that the two lovers are said to be reincarnated, as Helgi and Kara (Helgi II, Poetic Edda $141)$.

In Volsungs Helgi and Sigrun are permitted a happy ending. She asks him to fight Hodbrodd as she has 'sworn that [she] would no sooner have him than a young crow' (Volsungs IX 48). ${ }^{195} \mathrm{He}$ agrees, and with a large following she later directs Helgi and his men into a good harbour, from the air, showing her usefulness in battle (Volsungs IX 49). In the battle when the shield-maidens arrive it is 'like looking into a fire' (Volsungs IX 50). ${ }^{196}$ Helgi kills Hodbrodd, becomes king, marries Sigrun and they live happily ever after (Volsungs IX 50). This is a fairly significant contrast to the poems, although not incompatible.

One final story can be closely associated with Helgi and Sigrun, which is the account of Regner and Svanhvita in History. Hading's daughter Svanhvita journeys to Sweden with her sisters as retinue in an attempt to prevent the death of Regner and his brother. She stops her sisters dismounting among the monsters (History II

\footnotetext{
${ }^{194}$ See Ch. 2: Death and Desire and Disloyalty to Family Due to Romantic Relationship.

195 'Ek vil eigi eiga hann heldr en einn krákuunga'.

${ }^{196}$ IX 'Svá sem í loga sæi'.
} 
[43] 39), ${ }^{197}$ and admires Regner more after he gives his story, telling him his noble descent is obvious (History II [44] 40). When he is embarrassed about his state of dress and thinks she is making fun of him, she is amazed at his determination, promises him an unbeatable sword, and reveals her beauty. She agrees to marry him and gives him a sword with her blessing. After singing for a while she dismisses her companions and spends the night fighting monsters. She wins the kingdom for Regner, and 'Regner for her own bed' (History II [45] 42). ${ }^{198}$ She later fights her brother Frothi and wins. They are suspicious of each other's actions, and she has to remind him that he had granted her the freedom to marry whom she wished, and requests that he allow her to enjoy her husband (History II [45-6] 42). They make peace, and this story also has a happy ending.

Snorri tells us that those whose function it is to wait in Valhalla are valkyries. Odin sends them to every battle, where they allot death to men, and govern victories.

Gunn, Rota and Skuld always go to choose who will be slain and to govern killings (Gylfaginning XXXVI, Prose Edda 31). They are always associated with death, such as when they are at the burning of Baldr (Gylfaginning XLIX, Prose Edda 49). Saxo shows their magical abilities, such as when Rua has Biarki look through the crook of her arm in order to see Odin in History (History II [63] 60).

Several of the other fornaldarsögur contain valkyries, although their characters are not so complex, nor so well explored. Most are evil. In Sorli, Hedin is told about Hogni by a valkyrie, Gondul. She is tall, beautiful and polite. She tells

\footnotetext{
${ }^{197}$ Davidson in History II, p. 41, note 14, compares her to the 'luck' or dísir of the family, passed on through the generations and personified as a female guardian spirit.

198 'Sibi vero Regneri torum conciliavit'.
} 
him that she knows of one man equal to him, and encourages him to meet Hogni (Sorli V 79). Hedin later meets the valkyrie again and is consumed by lust for her. She gives him magic ale to drink, and tells him he is not Hogni's equal as he has not married a queen of a good family. When he says he could have Hild for the asking she says that he must kidnap her, and slice her mother the queen with the prow of his ship (Sorli VII 80-1). The magic ale makes him forget his vows of bloodbrotherhood. He goes back to see Gondul before leaving, and she is pleased with the result. He falls asleep on her lap after another drink, and she lays Odin's spell on him. He wakes and sees her fading ghost, which seems dark and large (Sorli VII 812). The resulting battle between Hogni and Hedin lasts 143 years, while Hild has to watch (Sorli VIII 83). Gondul is merely the agent of Odin, and the battle is due to Freyja's actions rather than her own. ${ }^{199}$ Nonetheless, she is one of the most sinister valkyries in the fornaldarsögur.

When Asmund is afraid of fighting eleven men, his dísir visits him in his dreams as two armed women, and tells him not to be afraid (Asmund VIII 98). Although dísir were originally fertility spirits, in some stories they are credited with martial behaviour. ${ }^{200}$ They are guardian spirits, so presumably these militaristic apparitions will be on the battlefield protecting him like valkyries.

It is interesting to note that valkyries can be referred to in a variety of ways. There are a number of standard valkyrie names, usually based upon the element hildr (battle), svanr (swan), or sigr (victory). The Prose Edda lists a series of kennings

${ }^{199}$ See Ch. 3: Maiden Warrior.

${ }^{200}$ Jochens p. 38. 
associated with valkyries: battle is the weather of valkyries, and weapons and armour can be referred to in terms of death maidens (Skaldskaparmal LX, Prose Edda 117-8). One kenning given by Viga-Glum for valkyrie is 'Gore-jewel[sword]lady' (Skaldskaparmal LXXV, Prose Edda 138). ${ }^{201}$ They are also called 'ladies of the fray' (Skaldskaparmal, Prose Edda 80). ${ }^{202}$ Freyja, similarly, is possessor of the fallen slain (Skaldskaparmal XXVIII, Prose Edda 86). Women in general can be referred to in terms of the ásynjur, valkyries, norns and dísir (Skaldskaparmal XXXIX, Prose Edda 94). For a man, being called a valkyrie can be an insult to his masculinity, despite their activity in battle, as is depicted in the flyting scene in Volsungs when Sinfjotli accuses Granmar of being a valkyrie in Asgard (Volsungs IX 49). Valkyries are a prevalent image in Old Icelandic heroic and mythological literature.

\section{Magic in battle}

While magic is mostly covered in Chapter 1, it is worth having a short paragraph here to reiterate how it directly influences the battlefield. Battle is the domain of men, but women affect it in more ways than by being warriors or collectors of the dead. Some also use their magic to influence the battle, often from within the fray, and can turn the outcome of a battle. Skuld uses her magic in battle to defeat her brother Hrolf (Hrolf Kraki [XXXIII] LI 76). In Arrow Odd, the priestess stands by the gates of her city and shoots arrows from all her fingers, as well as speaking in

\footnotetext{
20175 'dísar / dreyra mens'.

${ }^{202}$ Verses not in online edition.
} 
verse with Odd (Arrow-Odd XXIX 113). In a battle in Hromund, the sorceress Lara, in the form of a swan, howls with magic so that men forget to protect themselves, so that all Hromund's brothers are killed (Hromund VI 9). Male magicians occur occasionally, such as Grim Aegir (Gongu-Hrolf II 31), ${ }^{203}$ but it is more common for a woman to be magically involved in the battle. They may be outside their usual domain, but with the role of valkyries, shield-maidens and maiden warriors in Old Icelandic literature, women performing magic in battle does not feel out of place.

\section{Men in the domain of women}

Just as women operate in the world of men, sometimes men act in the domain of women, which is possibly more of a transgression in medieval Scandinavian society. ${ }^{204}$ It is more common for the male figures of the myths than of the heroic sagas to dress as women. Sometimes the disguise is a necessity, but sometimes it is a 'perverted' choice. It can be an occasion for humour, as in Prymskviða, but this is not always the case.

Loki is the most notorious cross-dresser, as well as being transgender. Perhaps this should not be surprising, as he often changes shape as well. ${ }^{205}$ Whereas Thor is greatly concerned about his masculine reputation when he is told to dress as Freyja, in bridal clothes, Loki jumps at the chance to dress as a bridesmaid. What for Thor is shameful and demeaning is an opportunity for fun and mischief for Loki: compare Thor's 'The AEsir will call me a pervert, / if I let you put a bride's veil on

\footnotetext{
${ }^{203} \mathrm{cf}$. Odin described as a wizard in Lokasenna XXIV, Poetic Edda 89 and Grim Aegir in battle and casting spells in Gongu-Hrolf III 33-5.

${ }^{204}$ See Ch. 2: Wanton Behaviour.

${ }^{205}$ See Ch 1: Shape-changing.
} 
me' to Loki's voluntary 'I'll go with you to be your maid' when he sees Thor getting dressed up in bridal linen: Loki is excited about the adventure, and dressing up is part of it (Thrym XVII, XX, Poetic Edda 99). ${ }^{206}$ Loki also does a far better job of acting as a woman, and covers up Thor's unconcealed masculinity in Thrym's home (Thrym XXVI, XXVIII, Poetic Edda 100).

Another instance of humour occurs when the AEsir look likely to lose Freyja (and the sun and the moon) to the giant master-builder, due to Loki's suggested plan: Loki is threatened with death if he does not remedy matters. He goes as a mare to distract the builder's horse, Svadilfaeri, and succeeds in preventing the builder from completion. Later he gives birth to a foal, Sleipnir (Gylfaginning XLII, Prose Edda 35-6). Considering that Loki impregnates women and has offspring with them, the fact that he is able to get pregnant and give birth himself implies some considerable ability at gender switching (Gylfaginning XXXIII-XXXIV, Prose Edda 26). Interestingly, it is the creature that he himself gives birth to that is good, as an amazing eight-legged horse, whereas the offspring he has with the giantess Angrboda bring about the end of the gods at ragnarök (Gylfaginning LI, Prose Edda 53-4). Loki's transgender birthing abilities can be viewed negatively, as in Lokasenna Njord, speaking to Loki, says

'That's harmless, if, besides a husband, a woman has a lover or someone else; what is surprising is a pervert god coming in here who has borne children.' (Lokasenna XXXIII, Poetic Edda 90)

\footnotetext{
${ }^{206}$ Thor: 'Mik munu æsir / argan kalla, / ef ek bindask læt / brúðar líni’. Loki: 'Mun ek ok með pér / ambótt vera'.
} 
Njord is on the defensive after being verbally abused by Loki, but nonetheless this does show some consternation at a man giving birth.

Loki can be malicious. Another occasion on which he disguises himself by changing gender is when he goes to learn from Frigg Baldr's vulnerability (Gylfaginning XLIX, Prose Edda 48); later in the same story he disguises himself as the giantess Thanks and refuses to weep for Baldr, thus preventing him from coming back to life (Gylfaginning XLIX, Prose Edda 51). Ironically, the messenger goes to Hel (Loki's daughter) on Sleipnir (Loki's son) in order to bring Baldr back to life, but it is only Loki himself who prevents this.

Loki also accuses Odin of womanish behaviour in Lokasenna, when he says 'But you once practised seid on Samsey, / and you beat on the drum as witches do, / in the likeness of a wizard you journeyed among mankind, / and I thought that the hallmark of a pervert' (Lokasenna XXIV, Poetic Edda 89). ${ }^{207}$ Seiðr is a magical art usually practised exclusively by women and the Vanir. ${ }^{208}$ Exactly what Loki is referring to in this is unclear, but Odin frequently crops up wandering around in disguise, and on at least one occasion he uses a female disguise in a situation which could be described as perverted. In History, Saxo tells the story of Odin attempting to seduce a girl who keeps turning him down. On his fourth attempt he dresses in woman's clothing, pretending to be a female physician. He gets to touch the girl's calves and upper thighs when he washes her feet. When she gets sick he tells her that she must be tied up due to the bitterness of the medicine, and then rapes her (History III [77-8] 71-2). Saxo says the gods threw Odin out for this behaviour. Some

\footnotetext{
207 'En pik síða kóðu / Sámseyu í, / ok draptu á vétt sem völur; / vitka líki / fórtu verpjóð yfir, / ok hugða ek pat args aðal'.

${ }^{208}$ Dumézil p. 40 ; Jochens p. 73-4/
} 
believed he should not be reinstated as by 'adopting actors' tricks and women's duties, he had brought the foulest of slurs on their reputation' (History III [78] 72). ${ }^{209}$ The gods of Saxo's History are flawed, and not intended to be revered. Writing in a post-pagan context, Saxo lowers the gods far more than Snorri in his Edda and Heimskringla, showing the falseness of past worship, and this story of Odin is a particularly vile one.

There are a few instances of heroes dressing as women as well. In Hromund's Saga, when the wise couple are hiding Hromund they dress him as a woman and set him to grinding corn (Hromund VIII 11). Due to their undeniable masculinity, the heroes in disguise sometimes have to pretend to be fighting women. Helgi is thought to be a valkyrie in his disguise (Helgi II II-IV, Poetic Edda 132-3), and when Hagbarth goes to Signe in women's clothing, he pretends to be one of Haki's fighting women. When the slave women asked why his feet were so hairy and his hands not soft, Signe said you couldn't expect a warrior woman to be otherwise (History VII [214] 195). This is interesting, as the warrior women and valkyries in this chapter are nearly always described as beautiful. These female disguises are effective, and do not seem to emasculate the heroes as they do the gods. Nonetheless, they are only applied in desperate situations.

\section{Conclusion}

Throughout Old Icelandic heroic and mythological literature, and Saxo's History, women who act in the world of men are constantly to be found. Sometimes they

\footnotetext{
209 'Scænicis artibus et muliebris officii susceptione tæterrimum divini nominis opprobrium edidisset'.
} 
have to deny their femininity, but if this is the case, they will at some point revert to it, having been overcome by males. Sometimes their femininity plays a key part of their actions, such as in battle or when using magic. On the whole, little judgement is passed on women acting in an arena usually reserved for men. While they may never quite be equal to the optimum male hero, they are not despised. When a man, disguised as a woman, is thought to be a warrior woman, this is not necessarily an insult. Yet, for men to act in the world of woman is far more despicable than the reverse. 


\section{Chapter Four: Murderous Women}

\section{Introduction}

This chapter discusses occurrences of women killing or causing grave injury, elsewhere than on the battlefield. Not all of these attempts are successful, but usually the intent is genuine. On the whole, harm is inflicted on those closest to them: themselves, through suicide; their children, their husbands and lovers; and other members of their households. Women both kill by their own hands and incite others to do so on their behalf. Reasons for killing are diverse, but are usually heartfelt. The women of the Volsung stories are particularly predominant in this section.

\section{Suicide and dying of heartbreak}

Suicide comes up in an array of places. Stories of the Volsung women committing suicide, due to despair, are told again and again. In the riddarasögur women are generally less violent, and in a state of despair are more likely to die of a broken heart. While this is not suicide, the fact that they give up on life means that the result is the same, and that they have some control over their lives. Suicide and dying of a broken heart are different ways of showing the same emotion, appropriate to each genre. These genres overlap a little, as there is at least one episode in the fornaldarsögur of a woman dying of a broken heart, and, on occasion, suicide does happen in the riddarasögur as well.

\section{Suicide}


In Volsungs, Signy's tragic suicide is arguably the most poignant scene. Her actions do not have Brynhild's deliberate grandeur, but are no less heartfelt. She has done what she believed she had to, in bringing about the death of her husband at any cost. However, the lengths she has gone to mean that she no longer regards herself as worthy to live: 'I have also granted so much to happen so that vengeance be brought about, that for me there is no choice of life' (Volsungs VIII). ${ }^{210}$ In order to act with honour for her kin, and avenge them, she has had to defile herself in incest, and kill her children. ${ }^{211}$ She has not been able to honour her husband as she should have. At last, she is able to put her husband first, and she chooses to burn with him, thus acting as proper loyal wife, and purging herself of her crimes. Like Njal's wife Bergthora, the suggestion of leaving her husband to burn alone is not an option (Njal's Saga CXXIX 221). ${ }^{212}$ Unlike Bergthora, Signy does not love her husband, but she is nonetheless faithful to him when her conflicting loyalties allow her to be. She herself is at the bottom of her personal rank of loyalties. The honour which her unwitting brother offers is unacceptable to her: she does not see herself worthy of any honour, as she has totally abased herself (Volsungs VIII 47). Brynhild's death, to a certain extent, is of her own choosing, but Signy sees hers as obligatory.

Brynhild's Dido-esque suicide is most certainly more famous, and is told in many texts: Nornageststhattr, Volsungs, Gudrun I, Sigurdarkvida in skamma, Niflungs, Oddrun and Skaldskaparmal are the Old Icelandic versions. Her reason and method are always the same. From the moment she finds out about Sigurd's

\footnotetext{
210 'Hefi ek ok svá mikit til unnit at fram kæmisk hefndin, at mér er með engum kosti líft.' Translation mine.

${ }^{211}$ See Ch. 2: Incest, Ch, 3: Infanticide.

${ }^{212}$ Robert Cook (trans.), Njal's Saga (London: Penguin, 2001). E.V. Gordon, An Introduction to Old Norse (Oxford: Oxford University Press) p. 97.
} 
treachery, she no longer wants to live (Volsungs [XXXI] XXIX 88). She kills herself because of her grief at the death of her beloved Sigurd, which she had brought about, and because she had unwittingly broken her vow to marry only the best warrior. Both she and Signy are driven to kill themselves because of their tainted honour. Brynhild's honour was damaged by the deceit of other people, whereas Signy soiled her own. She runs herself through with a sword and is burnt on a pyre with Sigurd, as she requested, in a re-enactment of their 'marriage' bed (Volsungs [XXXIIXXXIII] XXXI 92-3). Gunnar tries to stop her committing suicide, and offers her compensation, but she is not interested (Volsungs [XXXII] XXXI 91). Hogni refuses to try to stop her, as 'she has never been any good to us or to any man since she came here' (Volsungs [XXXII] XXXI 92). This suicide has repercussions, as Atli blames Gunnar and Hogni for his sister's death, and demands Gudrun as a wife by way of compensation. He later kills the brothers, at least partly because of Brynhild's death, as well as his desire for Sigurd's gold (Niflungs, Poetic Edda 195).

Gudrun wishes to kill herself on several occasions, but never actually does. When she is in the woods with the dead Sigurd, Gudrun also wants to die (Gudrun II XII, Poetic Edda 197). Atli later tells her she ought to be stoned and burned, but she seems to be aware of some other future, as she says that this will not be her death (Volsungs [XL] XXXVIII 104). After burning down Atli's hall she does not want to live, but 'her final day had not yet come' (Volsungs [XL] XXXVIII 105). She goes into the sea with stones in her arms to try to drown herself, but somehow the waves carry her across the sea, and she is married to King Jonakr and starts another family (Volsungs [XLI] XLIX 106). In Guðrúnarhvöt Gudrun intends to die and wants a 
pyre built, but we do not see this carried out (Gudrunarhvot XXI, Poetic Edda 237). She wants to die because of despair, rather than damaged honour. The emphasis is placed on the fact that she has seen everyone she loved die, usually bad deaths, but her punishment is surviving them all: 'May fire burn up the breast so full of wrongs, / may sorrows melt, heavy about the heart' (Gudrunarhvot XXI, Poetic Edda $237)^{213}$

Other stories of suicide can be found among the fornaldarsögur. In Yngvar, the elder two daughters of King Siggeus kill themselves because they begrudge their sisters their share of the inheritance (Yngvar VII 28). In Heidrek, Helga is so distraught when her husband Heidrek kills Harald, her father, that she hangs herself (Heidrek VII 26). The story of Ingebjorg and Hjalmar is tragic, in both its variations. Her father will not allow them to marry, and on his journeys with Arrow-Odd, Hjalmar is killed by Angantyr and his brothers. When Odd returns to give Ingebjorg the song and bracelet which Hjalmar sent, in Arrow-Odd she dies upon hearing the news (Arrow-Odd XV 69), and in Heidrek she kills herself (Heidrek III 10). Ingebjorg is an obedient, courtly woman, and because of obeying her father's wishes her life and chance of happiness are destroyed. Arrow-Odd hopes that they will be able to enjoy each other in death (Arrow-Odd XV 69). These two variations illustrate the relationship between suicide and dying of a broken heart. Ingeborg, in Thorstein Vikingsson (different to the Ingeborg above), says that she would rather kill herself than marry Ogautan (Thorstein Vikingsson XVII 47), so he turns her into a troll. In this case, the threat of suicide is intended as an insult.

\footnotetext{
${ }^{213}$ Verse in online edition is XX: 'Megi brenna brjóst / bölvafullt eldr, / prungit um hjarta / piðni sorgir.'
} 
History also includes some stories of suicide. Gunnild does not want to survive her husband, so she stabs herself in order to follow him in death (History I [27] 27). The story of Signe and Hagbarth is more developed. Signe unexpectedly, and secretly, falls in love with Hagbarth. The drama heightens as her brothers kill his brothers, and Hagbarth kills Signe's brothers in return (History VII [214] 194). Hagbarth's life is forfeit, and so the lovers are now doomed. During their one night together Hagbarth wants to know whether Signe will die if he does: she promises that she will (History VII [215] 195-6). He tests her by asking for a fake signal to be given when he is at the gallows. She and her maids all commit suicide by hanging themselves by their gowns and setting the room alight. When her rooms go up in smoke he knows she has done as she promised, and he is pleased at her loyalty, and happy to die (History VII [217] 197-8). ${ }^{214}$ He seems convinced they will be reunited in death. Her loyalty to him, through suicide, makes him happier than if she had continued to live without him.

There are a couple of examples of women dying of heartbreak in the Eddaic sources: when the dead Helgi does not return to Sigrun, she soon dies of grief (Helgi II, Poetic Edda 141). This is a contrast to the other, more forceful shield-maiden, Brynhild, who takes her own life when she cannot have the man she wants. Nanna dies of grief at Baldr's funeral, and is burnt on a pyre (Gylfaginning XLIX, Prose $E d d a 49)$. This suits her personality as she is only ever spoken about in terms of her relationship with Baldr. It would be hard to imagine her living without him, and yet she is not of the martial type who could take her own life. In both of these cases it is ${ }^{214}$ See Ch. 4: Killing Servants. 
hoped or presumed that the couple will meet again after death: reference is made to Helgi and Sigrun being reborn, and both Nanna and Baldr are kept in Hel's domain.

\section{Dying of heartbreak}

The idea of dying of heartbreak comes up again and again. Some cases are borderline suicide. To commit suicide usually shows a deep grief, which is certainly the case with Signy and Brynhild, but is more of an active choice than passively fading away. Dying of heartbreak, or wishing to die, comes up most often in the riddarasögur. It suggests deep grief and despair, but often the phrase 'dying of a broken heart' can be a huge exaggeration of the truth, and may function more as a threat.

In the Ivan stories, the lady first says that she loved her dead husband so deeply that she wants to die of grief (Haerra 11.1161-2 62-63), but she quickly recovers. In Iven, after saying she wants to kill herself, she tells her maid Luneta that it is better to die of grief than live (Iven V 52-53). Luneta recognises this as rhetoric, and pushes on with her matchmaking. Later, when Iven has forgotten his lady, a messenger comes and tells him that he, Iven, has killed by forgetting her, as she lies in her bedroom heartsick and grieving, and cannot rest (Iven IX 68-69). In reality, it is only Luneta's life that is in danger, due to her lady's rapidly changing mind. ${ }^{215}$

The stories of Tristram and Isond are more sincere in their approach to dying of a broken heart. Tristram dies of a broken heart when he thinks Isond has left him, and she dies upon seeing him dead: in Tristrams ok Isondar this is almost as soon as she sees him (Tristram ok Isondar CI 220-3), and in Tristram and Isond after three

${ }^{215}$ See Ch. 4: Killing Servants. 
days (Tristram and Isond XIV 288-289). In the same stories, Blenzibly has a similar experience. When Kanelangres leaves she is devastated, and talks about dying (Tristram ok Isondar XIII 44-45). She says she would rather have sudden death than their love ripped apart (Tristram and Isond III 250-251). When he dies in battle, in Tristrams saga ok Isondar she tries to kill herself, but goes into labour for three days before she dies (Tristram ok Isondar XV 46-9). In Tristram and Isond, when Kalegras is wounded in battle Blenzibly dies a couple of days after him, from grief (Tristam and Isond V 256-257). Another genuine case of dying of grief occurs in Parceval, with Parceval's mother dying of grief when he leaves (Parceval XII 152153). In these cases grief is a powerful enough force to bring about the end of a life without any physical assistance.

Examples of threatened suicide can be found in the Tristram sagas, when the Queen tells Tristram that Isond would kill herself rather than marry the steward (Tristram ok Isondar XXXIX 104-105), and later Isond herself tells Mariadokk that she would rather take her life than love him (Tristram ok Isondar LXXII 174-175). The maiden in the castle says she plans to kill herself in Parceval, as she has nobody to fight on her behalf (Parceval VII 132-133). This makes Parceval take on the challenge. In Erex Saga Evida intends to kill herself when Erex appears to be dead, although Earl Placidus arrives and prevents her, saying it is inadvisable to lose life, soul, and eternal salvation (Erex Saga XI 250-251). ${ }^{216}$ None of these are examples of actual suicide, but of people who are desperate enough, at least to use such rhetoric, to think that death is a better option than life. The only people to actually die of

\footnotetext{
${ }^{216}$ Marianne E. Kalinke (ed.), Norse Romance. Vol. 2: The Knights of the Round Table (Cambridge: D.S. Brewer, 1999).
} 
broken hearts are Tristram, Isond, Blenzibly, Parceval's mother, and Ingebjorg in Arrow-Odd.

\section{Infanticide}

Some of the highest drama in the Eddaic tales and the fornaldarsögur occurs when Signy and Gudrun bring about the deaths of their children. The Signy episodes only happen in Volsungs. She hopes her children will be of assistance to Sigmund when the time comes to avenge their father's death. However, her first child is afraid of the snake in the sack, and Sigmund does not want him as a companion. Signy says that Sigmund should kill the child, and so he does. The same happens with her next child, although the story is not actually told (Volsungs VI 42). When she brings Sinfjotli to Sigmund, he passes the tests, and Sigmund spends the next few years preparing him further, protecting him from harm where possible (Volsungs VII-VIII 43-5). When the appointed day of revenge comes, another son of Signy's discovers Sigmund and Sinfjotli hidden in the hall. The child tells his father Siggeir, and Signy takes both her young children, and asks her kinsmen to kill them (Volsungs VIII 45). Sigmund says he could not kill her children, but Sinfjotli does so (Volsungs VIII 46). ${ }^{217}$ These deaths seem unnecessary: while the deaths of the first pair could be seen as a protective action, enabling Sigmund's survival to remain a secret, there is nothing more that the last pair of children could reveal, and their murders can only have two purposes: either to punish the children for revealing the secret, or to ensure

\footnotetext{
${ }^{217}$ Presumably the two stories of killing Signy's children are merged from different sources, and in one version Sigmund kills her children, whereas in the other Sinfjotli kills them. If this is the case, Signy probably only ordered one pair of children to be killed, rather than two. The important thing is that she asked her kinsmen to put her children to death.
} 
that Siggeir knows that he will have no heirs to succeed and avenge him. ${ }^{218}$ While Signy seems extremely cold-blooded and unloving in her actions, she later shows remorse: 'I have worked so hard to bring about vengeance that I am by no means fit to live' (Volsungs VIII 47). ${ }^{219}$ She never expresses a personal attachment to the dead children, but does acknowledge the dishonourable nature of her actions. The infanticide is shocking, but from her perspective she only does what is necessary in order to act honourably on her own terms on behalf of her dead father and brothers.

Gudrun is responsible for the death of her children both directly and indirectly. Some she sends to their deaths, such as Svanhild in her marriage to Jormunrekk (Volsungs [XLII] XL 106), and her sons by Jonakr when she sends them to avenge Svanhild ([XLIII] XLI 107). Svanhild's death was not foreseen, but Gudrun probably expected her sons to die. Much more violent is the episode following the ambush on her brothers in Atli's hall. Before Brynhild died, she had predicted that Gudrun would kill Atli and his sons, and Atli himself dreamt about his sons dying. ${ }^{220}$ This story of infanticide occurs in Volsungs, Atlakvida, Atlamal and Skaldskaparmal. Once her brothers have been killed, Gudrun seizes her two sons by Atli and kills them, although they tell her she will be ashamed. According to Atlamal, her 'fierce children' are 'aghast but they did not cry' (Atlamal LXXVII, Poetic Edda 229). ${ }^{221}$ When they ask her what she intends, she says 'I've long wanted to cure you of old age'. They tell her that her 'anger will not be slaked for long'

\footnotetext{
${ }^{218}$ Jochens p. 140.

${ }^{219}$ Byock's translation has a slightly different emphasis to the original 'I have no choice to live'.

${ }^{220}$ See Ch. 1: Prophecy.

221 'Glúpnuðu grimmir / ok grétu peygi'.
} 
(Atlamal LXXVIII, Poetic Edda 229), ${ }^{222}$ but she ruthlessly cuts their throats. In all the versions, she has their skulls smithed into goblets, and has Atli drink wine (or mead) mixed with his children's blood from these goblets (Atlamal LXXXII, Poetic Edda 229), and has him eat their roasted hearts (Atlamal LXXXIII, Poetic Edda 230). When Atli finds out, he tells her she is cruel and ought to be stoned to death and burned on a pyre (Atlamal LXXXV-LXXXVII, Poetic Edda 230). She tells him that her desire was to bring grievous shame on him (Volsungs [XL] XXXVIII 104). She hurts him in the deepest ways possible, by proving her disloyalty to him, killing his sons who might have avenged him and continued his kingdom, and making him guilty of a great shame in eating his children. ${ }^{223}$ In doing so, she commits a great crime herself. Gudrun is ruthless but thorough in her revenge of her brothers.

While Signy and Gudrun both seem able to bring about the deaths of their children due to their heightened passion, this is not ordinarily the case. Besides these two women, the only other episode of attempted infanticide I have come across in the fornaldarsögur is in Ali Flekk, where Solbjart is told by her husband that if her baby is a boy it must be exposed (Ali Flekk I 43). It is later revealed that her husband had had premonitions about his association with trolls (Ali Flekk IV 46). Nonetheless, although she is sad, when the boy is born she has two slaves take him and put him under a tree, and she believes that he is dead (Ali Flekk II 44). He is rescued by another couple, and later reunited with his parents (Ali Flekk II-III 44-5).

\footnotetext{
222 'Lyst várumk pess lengi / at lyfja ykkr elli' 'skömm mun ró reiði'.

${ }^{223}$ Compare to Hvit forcing Bera to eat Bjorn's flesh in Hrolf Kraki. See Ch. 1: Corrupting hero.
} 
This episode bears little relevance to the rest of the plot, except in the importance of his relationship to his foster-mother. ${ }^{224}$

\section{Killing natal family}

A woman is rarely directly responsible for the death of natal kin, but occasionally she may be indirectly. Hervor gives her son Heidrek the cursed sword Tyrfing which she had been told would harm her descendants (Heidrek IV 22). It does not bring harm to Heidrek, but his son Angantyr kills his brother Hlod with it (Heidrek X 57). She is heedless of Angantyr's warnings, as she is only intent on the honour it can bring her (Heidrek III 16). The sword would have been better left buried, and because it is not, kin-slaying comes about.

Most often, if women kill their male kin it is through plotting or inciting other people. Ulvild in History finally manages to bring about her brother Frothi's death, but by giving him a gift, a coat impenetrable to steel, under which he later suffocates (History II [50] 46). ${ }^{225}$ This is successful where her more overt attempts of fratricide failed. In other sibling rivalry, in Egil and Asmund, Eaglebeak enlists

\footnotetext{
${ }^{224}$ Although there is nothing else like this incident in the Icelandic texts I have looked at, a couple of comparisons can be made with other texts. In The Lays of Marie de France, the story Le Fresne examines child exposure. One lady slanders another when she has twins, saying that there must have been two fathers. The slandering lady herself later gives birth to twins, and so she plans to kill one in order to save her honour. The people with her do not allow this, but one woman takes the child and abandons it at the church. Years later the mother is reunited with the child, who was brought up by the Church, and she is forgiven both by her daughter and her husband. Glyn S. Burgess and Keith Busby (trans), The Lais of Marie de France (Harmondsworth, Middlesex: Penguin, 1986), pp. 61-7. In The Mabinogion, in the story Pwyll Lord of Dyved, Rhiannon is unable to give birth for two years, and when she does the child is stolen away. The other women falsely accuse her of murder, and she is treated appallingly. Again, the child is fortunately brought up by kind people, and mother and child are later reunited, while the slandering women are punished. Jeffrey Gantz (trans.), The Mabinogion (Harmondsworth, Middlesex: Penguin, 1976), pp. 59-65. Child exposure is a serious matter, and it is surprising that is does not come up more in Old Icelandic tales of pagan times, especially since child exposure was allowed even after the conversion to Christianity. Jesse Byock, Viking Age Iceland (Harmondsworth, Middlesex: Penguin, 2001), p. 300. The infanticide of the Volsungs is grimmer. ${ }^{225}$ See Ch. 1: Magical Protection.
} 
Thor's help, so that her sisters all kill each out of jealousy (Egil and Asmund XII 246). Eaglebeak does not kill them herself, but she desires their deaths and brings them about. Here, however, they are trolls, so it is perhaps to be expected that they might not feel the same familial loyalties. ${ }^{226}$

Offspring as well as siblings can be dangerous. In Book I of History, Hading's dead wife warns him in a dream that he has borne a bird, dangerous to him. A soothsayer interprets this as being his daughter. His daughter is Ulvild, and she does try to have him killed as she is insulted that he married her to a commoner (History I [34-5] 33-4). She provokes this husband into attempting regicide. In Book VI, Starkather warns Ingel to 'escape from your barbarous wife, / lest the she-wolf bear a litter like herself / and from you a beast arise which will prey on its father'. He fears her children might seek revenge because they have killed all her family (History VI 194). ${ }^{227}$ Whereas in Volsungs Siggeir and Signy's children are not deemed brave enough to avenge the murder of their mother's kin on their father, and perhaps would not want to, it could be expected that Ingel's wife might want to rear a child to exact vengeance for the murder of all her kin. Where the supposed child's loyalties might lie is uncertain.

\section{Killing step-kin}

Because families in Icelandic sagas can so often include a mixture of alliances, chances for conflicting loyalties abound: loyalty to your birth family should come

\footnotetext{
${ }^{226}$ Cf. The Saga of Ali Flekk where Nott's brother is quite happy to kill her in order to win his bride, as he never much liked her anyway (Ali Flekk XV 56).

227 'Sævam, si quid sapis, effuge nuptam, / ne lupa consimilem sibi fetum gignat et ex te / belua consurgat proprio nocitura parenti.'
} 
first, and loyalty to a husband's family second. Borghild exhibits this conflict in Volsungs, when, because her stepson, Sinfjotli, had killed her brother in a fight about a prospective bride, she tries to exact revenge on Sinfjotli on behalf of her family. Sigmund will not allow it, and instead pays compensation for the first time in his life. While she accepts it, she is not appeased and proceeds to try to poison Sinfjotli. He has the presence of mind to refuse to drink the first two times she offers the cup to him, and his invulnerable father drinks it instead. However, when she approaches him for the third time her taunting riles him, and the drunk Sigmund tells him to 'filter it through your mustache'. Sinfjotli drinks, presumably knowing his fate, and dies. Sigmund casts Borghild out because of this, and she soon dies (Volsungs X 501). Sigmund's great grief shows that his loyalty was to his son rather than his wife.

In Halfdan Eysteinsson loyalties are possibly even more entangled. Isgerd's husband is killed by Eystein, and she becomes his new wife, albeit reluctantly at first (Halfdan Eysteinsson III 173). One winter two men known as 'Grim' come to their court, and on a certain day the younger Grim whispers to the queen, who turns white and warns the king to be on his guard. He is killed in his bed by the older Grim (Halfdan Eysteinsson VIII 178-80), and it is later revealed that the younger Grim was actually the queen's daughter Ingigerd in disguise, who had plotted to kill her stepfather, in order to avenge him killing her own father. The cycle of killing has to be broken later when she wishes to marry Halfdan, Eystein's son and her own stepbrother. She promises amends for having had his father killed (Halfdan Eysteinsson XX 192-3). 
Other incidents include Hild cursing her step-grandmother, Grimhild, with an unpleasant death if she and her mother ever get free from Grimhild's curse (Illugi V 70), ${ }^{228}$ Atli's mother killing Gunnar (Oddrun XXXII, Poetic Edda 209), and Thorild trying to kill her stepsons by appointing them royal herdsmen in order to put them in danger, and then joining with the monsters that attack them (History II [43] 39). In these relationships it is usually the stepmother who is responsible for the killing, and she does it herself, rather than relying on other people. In a household of mixed loyalties this might be necessary. Stepmothers often have a bad reputation and are 'wicked', as is illustrated in History when Saxo accuses Thora of being a stepmother to her daughter, as a way of describing the horror of the incest she forces her into (II $[51] 47){ }^{229}$

\section{Killing of husband}

Yet again, about half of the examples in this section concern the women of Volsungs, specifically Signy and Gudrun, who both avenge the killing of their natal kin. ${ }^{230}$ Signy is compelled to kill her husband Siggeir because of her loyalty to her family. She had married him for the same reason, being obedient to her father, although she was unwilling (Volsungs III 38). Twice after her marriage she tells Volsung that she wants to leave Siggeir, but her father will not let her, saying it would be dishonourable (Volsungs IV-V, 39-40). What comes about instead is surely worse for Signy's honour. Her enforced loyalty to Siggeir comes through her loyalty to her family, but her family loyalty remains pre-eminent, at her own cost. She has

\footnotetext{
${ }^{228}$ See Ch.1: Cursing.

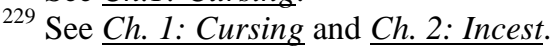

${ }^{230}$ See $\underline{\text { Ch. 1: Shape-changing, Ch, 2: Incest, } \text { Ch. 3: Maiden Warrior, } \text { Ch, 4: Suicide. }}$
} 
dishonoured herself in every way possible, through infanticide, incest and witchcraft, in order to kill her husband, which is also a dishonourable act. Her need to kill Siggeir goes far beyond her own personal desires; really, she is acting for a cause to which she had unswervable loyalty, which is ironically a system of honour. Her vengeance against Siggeir is not personal, but because of what he has done. She expresses no dislike of him as she brings about his downfall. Signy is first of all a daughter, and with those loyalties abated, is able to be a wife and share his death (Volsungs VIII 47).

This motif recurs later in the saga. Brynhild speaks of killing Gunnar, but Hogni puts her in chains and prevents this (Volsungs XXXI 85). She does bring about the death of Sigurd, whom she considers her first husband (Volsungs XXIX 82). The motif is played out fully in the story of Gudrun's second marriage. Like Signy, Gudrun shows reluctance in marrying Atli, but is compelled not only by family loyalty, but also by her mother's potions (Volsungs [XXXIV] XXXII 95). Different versions of the tale give different impressions of their relationship. Volsungs shows no sympathy between the two, but some of the poetry suggests that their marriage might have been happy, such as Gudrun III (Gudrun III, Poetic Edda 203-4). Brynhild prophesies on at least two occasions that Gudrun will marry Atli and kill him, first when Gudrun wants her to interpret her dream about Sigurd (Volsungs [XXVII] XXV 77), and later when she is about to die, saying in Sigurdarkvida in skamma it would have been better for Gudrun to have died with Sigurd (Sigurd sk LXI, Poetic Edda 190). Atli also had ominous dreams about Gudrun thrusting at him with a sword (Volsungs [XXXV] XXXIII 96). Like Signy, 
Gudrun seems to believe that she has no choice in what she does. She tries to warn her brothers to keep away from Atli, and when that fails she takes their side in battle, and later avenges them (Volsungs [XXXVIII, XL] XXXVI, XXXVIII 100-1, 104). The necessary part of her revenge entails killing her husband, and letting him know that he will not be avenged by any heirs. Even burning the hall and retainers is necessary, as he did not fight alone against her brothers. ${ }^{231}$ However, the way in which she does things adds a vicious dimension to her personality. To not merely kill (or have killed, like Signy) her children, but to turn them into food and eating vessels is moving into the barbaric, and Atli can rightfully call Gudrun 'cruel' (Volsungs [XL] XXXVIII 104). ${ }^{232}$ She kills him with the help of Hogni’s son, who is also entitled to see the slayer of his father dead. In Volsungs, Atli tells her she is not completely unjustified in killing him, but says it is dishonourable as their marriage was legitimate. She, in return, seems to acknowledge this, by promising him a magnificent burial (Volsungs [XL] XXXVIII 105). ${ }^{233}$

There are very few stories in the fornaldarsögur in which a wife is held responsible for her husband's death or attempted murder. In Half's Saga, Asa reveals her husband Hjorleif's hiding place, and at her bidding Hreidar hangs him up by his shoe thongs between two fires in the hall. He is freed by his other wife, and chooses not to have Asa drowned in a swamp, as he is entitled to, but sends her away with her dowry (Half VIII 12). She is an example of a 'bad' wife in her

\footnotetext{
${ }^{231}$ Cf. Njal ch. 130-158 where Kari escapes from the burning hall and continues the feud.

232 'Grimm'.

${ }^{233}$ This probably does not come to pass, as after burning down the hall Gudrun is carried away by the sea ([XLI] XXXIX 106). Perhaps it is ironic, and the burning hall is meant to be Atli's funeral pyre.
} 
disloyalty (with no reason except, perhaps, because she wants to be his only wife). In Heimskringla, Skjalv is compelled to marry Agne, who had killed her father. She requests a funeral feast for her father, at which her new husband gets very drunk. She tells him to be careful of his gold ornament, so he binds it around his neck and she hangs him by it (Ynglings XXII, Heimskringla 21). In doing this she is justifiably taking revenge, although she is secretive about her intent. Another incident in Heimskringla occurs in the story of Bera, Yngve and Alf. Bera is often complimentary of her brother-in-law, Yngve, with whom she gets on better than with her husband, Alf. Eventually, Alf gets angry and kills his brother, who also kills him. The blame for these deaths is given to Bera (Ynglings XXIV, Heimskringla 22).

History has a couple of instances of husband-killing, or attempted husbandkilling. Ulvild, a woman who is always plotting against her family, decides to kill her husband when he rejects her suggestions to kill her brother Frothi. However, her waiting woman reveals the plot, so her husband goes to bed in a cuirass. When Ulvild asks him why he has done this, he attributes it to a whim. When the plotters break in he annihilates them, prevents Ulvild from 'weaving stratagems against her brother', and warns other men 'to beware their wives' treachery' (History II [46] 43). ${ }^{234}$ Much later in the History a very different sort of husband-killing occurs. Lathgertha, formerly married to Ragner and an outstanding fighter, decides after a battle that she prefers to govern alone than to share the role with her husband, so she

\footnotetext{
234 'Insidiis fratri nectendis', 'uxorum perfidiam cavendi'.
} 
sticks a dart in her husband's throat, and seizes the whole title and sovereignty (History IX [283] 254). ${ }^{235}$

In Tristrams saga ok Isondar, Isodd the Dark brings about her husband's death. She deliberately lies to him, and tells him the approaching ship has black sails, which she knows for him would mean that Isond was not on board. He thinks Isond has forsaken him, and dies because of it (Tristram ok Isondar IC 220-221). This is not the same thing as actively plotting to bring about his death, but Isodd certainly intends to hurt him and cause mischief. The saga shows no sympathy for her although her husband was so engrossed in another woman that he had never paid attention to his wife.

\section{Killing suitor/lover}

Women, at times, kill both suitors and lovers. Thornbjorg the maiden-king tires of all the men who seek her hand, and some of them are killed (Hrolf Gautreksson VI 42). They know the risk they are taking when they attempt to woo her. Ingeborg, transformed into a troll, goes back to Ogautan, her suitor and curser, and hangs him before she returns to her human form. As she is in the form of a troll this does not reflect on her human personality, but means that Ogauatan can no longer be a problem in her life (Thorstein Vikingsson XIX 51). ${ }^{236}$

Killing a suitor is less personal than killing a lover. Some liaisons between lovers are, of course, not really relationships. When Yngvar's warcamp is approached by women he warns his men to be wary of them, and those men who do

\footnotetext{
${ }^{235}$ See Ch. 3: Maiden Warrior.

${ }^{236}$ See $\underline{\text { Ch. 1: Curses. }}$.
} 
not resist them are dead by morning (Yngvar VII 30). At Ingibjorg's instigation, Helgi of Helgi Thorisson is her on-and-off lover, but when she can no longer bear to sleep with him herself, yet does not want the women of Norway to do so, she gouges out his eyes and sends him away. He dies shortly after, although it is not made clear whether this is because of his wounds (Helgi Thorisson I-III 177-281). This Ingibjorg seems very cruel, and she and the women of the warcamp are probably supernatural.

Women sometimes express a wish to get revenge on their lover. Brynhild in Volsungs says that her greatest regret is that she cannot kill Sigurd herself (Volsungs [XXXI] XXX 87), as she sees him as the cause of her broken vows, broken heart and shame. Yet, she loves him and cannot bear to live without him. Her desperation causes her to destroy the two most important people in her life, herself and Sigurd. On a less grand scale, in Janual the queen Guinevere demands that the king get justice for Janual's disparaging words to her: she is ashamed because he rejected her advances and belittled her beauty (Janual 14-15). Her shame makes her act unjustly to hide her embarrassment and remove the one person who could tell the true story.

\section{Killing to gain a husband}

It is perhaps surprising that killing in order to gain a husband never really comes up as a motif, although the opposite, killing to gain a wife, is so common. It is never more than hinted at, such as when in Grim Shaggy-Cheek Geirhild dies and the following year the king marries Grimhild. While Grimhild is a troll and has wicked intentions, it is not even really suggested that she was the cause of Geirhild's death, 
although this might be conjectured (Grim Shaggy-Cheek I). Women are seldom shown in active pursuit of a desirable husband, but are either pursued themselves or given away by their fathers.

\section{Killing servants}

The killing of servants occurs sporadically. In some cases it is merely in the background of the story, but in the riddarasögur it is a test of character. In this section I am including the killing of ladies' maids, as they are subject to their mistresses, if not servants as such.

Brynhild, when she prepares to kill herself, in most accounts also kills a number of her servants. How many exactly varies: Volsungs recounts that she asks for four of her men, five bondswomen, eight attendants and two hawks to be burned on one pyre with her and Sigurd, as well as those who died with Sigurd, so that 'our funerary procession will not be unworthy' (Volsungs [XXXIII] XXXI 92-3) ${ }^{237}$ In Nornageststhattr, she herself slays seven of her thralls, and five handmaidens (Nornagestthattr 182). In Gudrun I it is eight slaves and five serving maids (Gudrun I, Poetic Edda 181). This killing shows the heightened setting which is the world of the Volsungs, with Brynhild almost godly in her authority. In one rendition of the story, Sigurdarkvitha in skamma, some of her maids and ladies seem to have killed themselves, rather than being killed to order (Sigurd sk XLVII, Poetic Edda 188). This shows Brynhild must have engendered a great loyalty among some of her followers, although some of her women refuse to kill themselves (Sigurd sk L, Poetic Edda 189). The story of her maids killing themselves is replicated in History,

\footnotetext{
237 'Er vár leiðsla pá ekki aumlig'.
} 
where all Signe's maids hang themselves with her, by their gowns, at her request. Although they had told her that they would do whatever she wanted, they may not have expected that she would want their lives. Nonetheless, they all go through with it, and Signe gives them wine for courage (History VII [217] 197).

Other examples of intending to kill servants can be found in the riddarasögur. In the stories of Ivan, Luneta is blamed when Ivan does not return to his wife, and the counsellors and lady together come to the decision to execute her. She is accused of treachery against her lady (Iven X 74-75, Haerra 1. 2915 140-141). In one version it is made clear that the steward envied her position, and it was he that brought about her predicament (Haerra 142-143). As a single woman without a knight to defend her, she is an easy target. Luckily, Ivan is able to step in and rescue her.

The story of Tristram and Isond shows Isond putting her maid, or fostermother, to the test. When Isond realises that Bringven is the only one who would be able to reveal her relationship with Tristram, she has her slaves take her to the forest to burn her on a bonfire. In Tristram and Isond, when the slaves ask her what she has done to incur Isond's wrath, Bringven makes an excuse without giving away the lovers, and Isond saves her life, as she knows she can be trusted (Tristram and Isond XI 276-9). In Tristram ok Isondar there is a different emphasis, as it is the slaves that save Bringven: when Isond finds out that Bringven had not betrayed her, she regrets her decision and decides she wants Bringven back. She threatens to put the slaves themselves to death if they do not restore her, and is very pleased when Bringven is returned to her (Tristram ok Isondar XLVII-XLVIII 122-25). This 
episode reveals far more about Isond than it does about Bringven. Threatening death to a servant in the riddarasögur is a way of trying to appease guilt about things that are not comfortable to acknowledge.

\section{Helping/inciting to kill}

Women are perhaps best known for their role in Icelandic literature as whetters, or inciters. ${ }^{238}$ Here, I will briefly discuss some women who bring about killing, either by inciting or by assisting the killer.

The best known inciters are Brynhild and Gudrun. Their precursor, Signy, also incites to a certain extent. Signy works on willing objects, as it is both her desire and Sigmund's to get revenge for their family by killing Siggeir. However, he does show more qualms when it comes to killing her children. ${ }^{239}$ Signy also provides the means for Sigmund to kill the she-wolf, Siggeir's mother, by having her man smear honey all over his face, which attracts the wolf and allows Sigmund to kill her (Volsungs V 41). She helps Sigmund survive so that one day he might avenge their family. Even when Sigmund and Sinfjotli are in the pit she aids them, by supplying them with Sigmund's sword (Volsungs VIII 46). Signy's role in the killing of Siggeir is at least as important as Sigmund and Sinfjotli's.

Sigmund's wives also try their hands at inciting, but with less success. Borghild wants him to outlaw Sinfjotli for killing her brother, but he refuses and offers her compensation instead (Volsungs X 51). Hjordis, when Sigmund is dying, says she wants him to avenge her father, but he tells her this is destined for another

\footnotetext{
${ }^{238}$ See Jochens pp. 162-203 for a much more in depth analysis.

${ }^{239}$ See Ch. 4: Infanticide.
} 
(Volsungs XII 54). When Sigurd asks for the fragments of his father's sword, she hands them over, and tells him he is likely to win renown (Volsungs XV 60). She does not need to whet him at all. Once the sword is repaired, his first task is to avenge both of their fathers (Volsungs XV 60).

In all the Icelandic tales regarding Brynhild, she incites the Gjukings to kill Sigurd. In Volsungs, when she finds out that she had been deceived by Sigurd into marrying Gunnar, ${ }^{240}$ she tells Gunnar she will never be cheerful again (Volsungs [XXXI] XXIX 85). In both Volsungs and Sigurdakvida in skamma, she threatens to leave Gunnar if he does not kill Sigurd and his son (Volsungs [XXXII] XXX 89, Sigurd sk X-XII 183). This is a very effective threat, and Gunnar agrees to kill Sigurd, despite their vows of blood-brotherhood (Volsungs [XXXII] XXX 89). However, due to their vows, he and Hogni are unwilling to do it themselves, so they persuade their brother Guttorm (who had not sworn vows) to do so instead: this is done with a mixture of witchcraft and Grimhild's inciting (Volsungs [XXXII] XXX 89-90). Brynhild is reported to both laugh and cry once the murder is done, which baffles them (Volsungs [XXXII] XXXI 91). Having Sigurd killed is a way for her to restore her honour, but it does not mean she is happy with the consequence. As Hogni says, her passion is too great, as she both loves and hates Sigurd in the extreme (Sigurd sk XIX 184).

\footnotetext{
${ }^{240}$ In the wooing scene with Sigurd disguised as Gunnar, Brynhild demands that he kill all who ask to marry her. He declines, saying he has already fulfilled her condition by passing through the flames ([XXIX] XXVII 81). But, the real Gunnar is in time called on to kill Sigurd, Brynhild's suitor, and complies ([XXXII] XXX 89).
} 
Gudrun continues this type of behaviour. Although, unlike Brynhild or Signy, she takes matters into her own hands against Atli, ${ }^{241}$ when her daughter Svanhild is trampled by horses she incites her sons to avenge her death. They are unwilling, but agree, and she advises them on how to attack (Volsungs [XLIIIXLIV] XLI-XLII 107-8). However, because they are unhappy about being sent off to die, two of them kill their brother Erp in order to hurt her, and because of this they are unable to follow her advice on how to attack, which required the three of them: they are killed themselves (Skaldskaparmal L, Prose Edda 105). In Gudrunarhvot her sons remind her that her brothers killed Sigurd, and that she killed her sons (Gudrunarhvot IV-V, Poetic Edda 235). In Hamdismal, her sons tell her that she will weep for them as well as her other dead kin (Hamdismal X, Poetic Edda 239). There is a hint that Erp is actually Gudrun's stepson, although she loves him more (Hamdismal XIII, Poetic Edda 240). Their deaths seem to be certain before they have even set out. Aslaug, daughter of Brynhild and Sigurd, later acts in the same way as Gudrun, as she sends her own sons to take revenge for her stepsons when they are killed, saying that she will help them in every way possible (Ragnar L X 222).

There are many other incidents of inciting. Asa, in Upplendings, incites a man to kill her husband Gudrod (Upplendings II). In a variation in Heimskringla, Aasa contrives that her husband, Gudrod, kills his brother Halfdan, and she also brings about Gudrod's death, before fleeing to her father (Ynglings XLIII, Heimskringla 37). When she is taken away by another Gudrod, she has her pageboy run up to him ${ }^{241}$ See Ch. 4: Killing husband. 
one night and thrust a spear through him. The pageboy is killed, and Aasa does not hide the fact that she had caused the killing (Ynglings LIII, Heimskringla 41-42). Also in Heimskringla, Driva bribes the witch Huld to bewitch Vanlande to return to Finland or to kill him. When he decides not to return, his nightmare treds on him and crushes him (XVI 17).

Skuld incites her husband against her brother Hrolf Kraki, and this causes his death (Hrolf Kraki XXXI 69-70). In Ragnar L, Grima incites her husband to kill Heimir so that they can get his gold, and, when he is unwilling, her threat of leaving him makes him do as she wishes (Ragnar L I 188). In Ali Flekk Thornbjarg incites Jotunoxi to kill his sister Nott, pretending that she will marry him if he does so (Ali Flekk XV-XVI 56-7). In Asmund, Asa causes Asmund to kill his brother in combat, and later asks for forgiveness (Asmund X 102). Gondul the valkyrie persuades Hedin to slice the queen with the prow of his ship, as well as to kidnap the princess (Sorli VII 81). In Egil and Asmund, Eaglebeak gives the two heroes information on how to kill her (troll) brothers (Egil and Asmund XV 252).

In History, Ulvild incites her husband to murder her father, saying she prefers to be queen than princess. She plans the murder by holding a banquet, but the plot is overturned (History I [35] 34). When Ulvild is remarried, she attempts to persuade her husband to kill her brother and take the kingdom, but when he will not respond to her plans she tries to kill him instead (II [46] 43). All these examples of inciting show that for women in these stories, the best way to get what they want is to persistently call the attention of their menfolk to it, or to 'nag'. Women in the fornaldarsögur and cognates get what they want through words more than actions. 


\section{Post-death}

Transgressions regarding the afterlife are rare. The story of Helgi and Sigrun in the mound, ${ }^{242}$ and other stories of women at gravemounds, ${ }^{243}$ show women interacting with the dead, but they had nothing to do with the killing. There is certainly a hint in other stories, such as Brynhild (Brynhild XIV 194) and in the Hagbarth and Signe episode of History (History VII [217] 198), of an afterlife to be shared by lovers. The various stories of Isodd the Dark incorporate both these aspects. Because of her deception, Tristram and Isond die of broken hearts. However, this is not enough for her jealousy: when they are buried, she makes sure that they are on opposite sides of the church, to ensure that they are still kept apart. Nature, or destiny, is against her, however, as trees grow out of each of their graves and intertwine overhead (Tristram ok Isondar CI 222-223). Isodd the Dark is depicted as a mean and small-minded person who gets in the way of true love.

\section{Killing by Supernatural Females}

Supernatural females are often responsible either for killing or for attempted killing. Troll-wives are the main culprits, but are not always successful. There is a recurring motif of troll-wives shaking boats. This happens in The Saga of Grim Shaggy-Cheek I, Ketil-Trout III, and Arrow-Odd V, all of which are stories about the men from Hrafnista. In each case the troll-wife (or troll-wives) is unsuccessful in what she is trying to do, presumably to injure or kill the hero, although she does wake him up.

\footnotetext{
${ }^{242}$ See Ch. 2: Death and Desire.

${ }^{243}$ See $\underline{\text { Ch. 1: Interaction with the Dead. }}$
} 
Troll-wives are shown as greedy and easily violent. In Arrow-Odd, the troll-wife tries to kill Odd and Asmund for a bracelet (Arrow-Odd V 40). In Ketil Trout, Ketil is told by a troll-wife that she has killed many men (Ketil Trout V). The troll Goldball attacks Halfdan, but he, thanks to a magical necklace, is able to rip her apart (Halfdan Eysteinsson XVII 188). ${ }^{244}$ Unimportant characters can be sacrificed to monsters and trolls, as in Arrow-Odd where a female monster kills sixty men (Arrow-Odd XX 83), and Geirrid kills eighteen men (Arrow-Odd XXIII 90). Another example of a troll-wife being violent is Nott, beating Ali in his dream with an iron lash, giving him wounds that will not heal and will kill him after ten years (Ali Flekk XII 53). Eaglebeak, the jealous troll-wife of Egil and Asmund, tries unsuccessfully to take revenge on the bride of a man she had wanted (Egil and Asmund XII 246). In Illugi, Grid is shown to be an effective killer, even once the curse is broken and she is no longer a troll: together, she and Illugi finish off the seven witches whom she had had to fight alone every night. When Bjorn calls her daughter Hild a troll-woman, Grid comes and hangs him as punishment (Illugi V-VI $71)$.

Other examples of supernatural females involved with killing attempts are more diverse. ${ }^{245}$ In Grimnismal, we hear that 'the dísir are against you' (Grimnismal LIII, Poetic Edda 59), showing that the dísir have the ability to appoint death. In Hymir, a giantess offers to hide Tyr and Thor, then deliberately reveals their hiding place, endangering their lives (Hymir IX-XII, Poetic Edda 79). In Volsung, the shewolf, possibly Siggeir's transformed mother, methodically bites the Volsung

\footnotetext{
${ }^{244}$ See Ch. 1: Magical Protection.

${ }^{245}$ See also $\underline{\text { Ch. 3: Valkyrie. }}$.
} 
brothers to death, one each night. It is only when her animal instincts are attracted to the honey in Sigmund's mouth that she acts differently, and so loses her own life instead of taking Sigmund's (Volsungs V 41-2). In Skaldskaparmal, the giantess Gialp makes a river rise when Thor is trying to cross it, so he throws a stone at her to stop her. Two other giantesses try to lift a seat under him, and he forces it down, breaking their backs (Skaldskaparmal XXVI, Prose Edda 82). The giantesses Fenia and Menia justifiably cause the death of their master, Frodi, as he makes them grind him wealth without resting; eventually, they grind an army against him (Gróttasöngr, Poetic Edda 260-3). Often, the expected role of supernatural females is to bring about death or violence to human men. Their differences to domestic human women are emphasised so that their violent behaviour is less shocking.

\section{General Death}

Mythology

Some general background to women and death is given in Gylfaginning. Old age, the ultimate killer, is depicted as the old woman Elli, who is able to bring even Thor down onto one knee, no matter how hard he struggles (Gylfaginning XLVI, Prose Edda 44). The dísir, norns, and valkyries are all female, and all have important roles in the death of men through battle and other prescribed ways. ${ }^{246}$ Loki's daughter Hel is thrown by Odin into Niflheim, where she is given authority over nine worlds and the people sent to her. These are the people who die of sickness or old age: ' $[\mathrm{H}] \mathrm{er}$ dish [is called] Hunger, her knife Famine... her threshold... Stumbling-block, her bed

\footnotetext{
${ }^{246}$ Larrington p. vii.
} 
Sick-bed, her curtains Gleaming-bale' (Gylfaginning XXXIV, Prose Edda 27). ${ }^{247}$ Her power, though designated by Odin, becomes independent. When a messenger is sent to her, she permits that Baldr may be returned to the living, but imposes very exact conditions which are not fulfilled: that all the living and the dead weep for him (Gylfaginning XLIX, Prose Edda 50). Odin is not able to over-ride this, and Baldr remains among the dead, with his wife Nanna. Interestingly, in History, the goddess of death (unnamed) appears to the injured Balder. She tells him she will have him in her arms in three days, and this comes to pass (History III [75] 69).

\section{History.}

Women are involved with death in History in a number of ways, both as killers and protectors from death. When he is attacked at night, Erik is saved from death by both his wife and stepmother ( $\mathrm{V}$ [140] 125). Frothi is killed by the horn of a woman disguised as a sea-cow, but she and her sons are killed in turn by his soldiers (V [157] 142). When Gunni stabs the queen, she threatens him and says he would not have got away if she were still alive (VIII [254] 231). Sivard's female relatives, who had been put in a brothel, flock to Regner in men's clothes, saying they would put death before dishonour (IX [280] 251). When Gorm says he will kill the one who tells him of his son's death, it is his wife Thora who lets him know what happened by acting out mourning rituals, so that nobody need be killed for uttering the fateful words (IX [297] 268).

\footnotetext{
247 'Heitir... Hungr diskr hennar, Sultr knífr hennar... Fallandaforað presköldr hennar... Kör sæing, Blíkjandaböl ársali hennar.'
} 


\section{Conclusion}

Brynhild, Gudrun and Signy are exemplary figures of women killers, as their stories and untimely death are inextricably intertwined. The influence of women on death is felt throughout these texts, in the instigation, if not always in the killing itself. Women do not need to get their hands bloody to bring about a killing, but Brynhild and Signy hold themselves as much to blame for the deaths of Sigurd and Siggeir, which they bring about, as Gudrun does for Atli, whom she stabs. Other women are more callous, especially troll-wives, and show no remorse. Death and despair are closely linked, especially as seen in the relationship between suicide and dying of heartbreak. For women to kill is a serious matter, but usually so are the reasons for which they do it. 


\section{Conclusion}

This thesis is a survey of a large number and variety of texts, and as such it is difficult to draw any over-arching conclusions. While some generalisations can be made, there are nearly always exceptions to these. Below are summarised some of the key points of my findings, although they are by no means all encompassing.

This survey did not show what I expected to find when I set out to examine the figures of transgressive women in the fornaldarsögur. When I began, I expected to find many characters like the women in Volsungs, acting with similar motivations. There are other women who can be compared to them in some aspects of their behaviour, but there are few such fully developed examples of transgressive women. Some others, such as Aslaug in Ragnar Lothbrokar, feel like relatively poor imitations, less passionate, and more difficult to sympathise with. Volsungs developed from a considerable body of Eddaic poetry, and probably other lost Icelandic texts, over several hundred years. ${ }^{248}$ This period of gestation, not to mention the varied sources, perhaps let the story develop its complexity. Sometimes this is to its detriment, as the stories of Signy and Brynhild are roughly put together in places.

Although traditionally included among the fornaldarsögur, the two most famous sagas, Volsungs and Hrolf Kraki are different from the others in several ways. One of the major differences is the fact that these sagas are tragic. Fate plays

\footnotetext{
${ }^{248}$ Larrington pp. x-xiii. Volsungs was written in the thirteenth century, whereas the poems about the Volsungs written in Codex Regius were composed several centuries earlier. The contemporary German Nibelungenlied and Norwegian Thidreks saga have some significant differences, especially a total lack of a Signy figure, and Gudrun's alliances, which in the Icelandic are to her kin, rather than her second husband, Atli.
} 
a large part in them, and usually goes against the heroes after a time. The best intentions can be destroyed in accidentally broken vows and the connivings of both men and women. Whereas in Volsungs and Hrolf Kraki honour is of great importance, this is not emphasised to the same extent in the other fornaldarsögur. These two are not so much episodic as dynastic. Because of these differences, the women in these two sagas would not necessarily suit other sagas of the corpus they have been put within.

Most of the fornaldarsögur are relatively cheerful, as the hero goes from adventure to adventure, often meeting interesting women along the way. While bad things, such as curses, may happen to women or be caused by women, the hero fixes them by the end of the sagas. In such a variety of sagas, there is a variety of women to be encountered: humans and trolls, queens and peasants, married and unmarried.

Women in the fornaldarsögur and the other texts I have looked at transgress in different ways according to their status. Queens have different opportunities from peasant girls: among other things, they can have their servants killed, or order other people to act on their behalf. Princesses are generally more helpless, and to get away from the authority of their fathers some, such as Ulvild, try to kill, and others, such as Thornbjorg, take on a masculine role. Peasant girls may be promiscuous, but they are seldom given the opportunity to be involved in a highly dramatic adulterous affair. Similarly, trolls and other supernatural figures live in a different realm and by a different code from humans, and are not expected to be chaste or peaceful. Trollwives are usually limited to trying to kill, save, or seduce heroes, and occasionally curse them. 
Transgressions can have beneficial consequences. Incest and pre-marital couplings in troll-caves bring about children who become heroes such as Hrolf Kraki, as well as villains like his sister Skuld, both in Hrolf Kraki. Being cursed can enable a usually passive person to equalise the situation by cursing in response, such as Hild in Illugi. What is sometimes disastrous, such as fighting in battle, can be of enormous benefit somewhere else, depending on the point of view of the narrator. In Helgi I, for Helgi Hundingsbani having a shield-maiden fight in battle with him is a great help, whereas in Hromund the swan-maiden Lara is devastating for the hero and his family. Transgressing is a way in which women who might ordinarily be silent figures can have their voices heard, and influence their life.

Interactions with the dead are extremely few. Even though the Prose Edda tells us that valkyries select the men to die on the battlefield and serve them in Valhalla, this is alluded to, rather than shown, in the other texts I have looked at. Shield-maidens come up with more frequency, but they cannot interact with the dead in the same way. Helgi accepts drink from Sigrun, as he would from a valkyrie, but he is unsettled by their interaction and never returns. She hopes for their romantic and sexual relationship to continue after death, but this does not happen. Hervor also encounters the undead at their gravesites, but unlike Sigrun she comes away satisfied. Their motives are different, but each ultimately gets what she desires: Sigrun is reunited with Helgi when she dies, and they are reincarnated, and Hervor gets the sword that will continue to bring fame to her family, although at a cost.

The fornaldarsögur in general are action-packed. The plots are driven by exploits rather than thought, and it is rare for the thoughts of the protagonists to be 
revealed in much detail. The women about whom I have written are usually as action-driven as the men, although sometimes they are limited by babies or other obligations. Unlike in Saxo's History, little commentary is given regarding the storyline or people's motives. Saxo likes to interject frequently, explaining and passing judgement. He disapproves of adultery, as in the story of Gunnvara; incest, regarding Yrsa and Haldan; and plotting against family members, such as the in the story of Ulvild, but he seems quite intrigued by the idea of women, like Lathgertha, in battle. These judgements can be useful to assess what might be considered transgressions in a medieval Christian Scandinavian society, but the Icelanders, also writing in Christian times, do not overtly pass judgement on their pagan past. It can be difficult to know what is transgressive, although the consequences for women, their judgements on themselves and the way other characters judge them can reveal this: in Volsungs, Signy shows that incest, adultery, shape-changing and infanticide are transgressive, at least in some cases, and Atli's reaction to Gudrun shows that disloyalty to a husband is also a heinous crime. In Thorstein Vikingsson the stepmother Grimhild is stoned because of turning her stepdaughter into a troll. Judgements can be made about transgressions by the place in which people live. In a world where different supernatural beings live in different realms, and by different values, the fact that these are already physical boundaries to cross in order to encounter these women suggests that they would be considered as transgressive merely by their location and natural differences.

The fornaldarsögur are set in a different reality from the myths. They are based on humans, rather than the asir, although sometimes the heroes, such as 
Arrow-Odd, seem as indestructible as gods. Yet, the characters in these sagas are more vulnerable than the asir, and women can have a more serious effect on them. Whereas the worst the ásynjur can do to the aesir is to cause them shame, as when Freyja is unfaithful to her husband, women in the fornaldarsögur, such as Hvit in Hrolf Kraki, can bewitch, curse and kill men, as well as dishonouring them.

Although both the riddarasögur and fornaldarsögur are medieval romance genres written in Iceland, the role of women within them is considerably different. The fornaldarsögur are about pagan Germanic times, whereas the riddarasögur are about a Christian Arthurian court, or similar. By far the most common transgression for women in the riddarasögur is adultery, which is to the shame of their lovers and husbands, more than to themselves, as is shown in Mottuls. Women are mostly background figures. They are often quiet, but involved in deceit regarding their fidelity, as is Isond in the Tristram sagas. In the fornaldarsögur, transgressive actions reflect on the women themselves, as well as on their close male kin. They are more likely to own their actions, as does the troll-wife Eaglebeak in Egil and Asmund. Women in the fornaldarsögur are not passive, and do not spend years lamenting their fate like Isond in the Tristram sagas. In her situation they would more likely dispatch one of the men, or themselves.

The women I have studied in the fornaldarsögur are fascinating characters, neither afraid to stand up for themselves, nor to transgress social norms. They can have a serious impact on the story, although they are seldom protagonists. Although some are stock characters, it is often the scenes with women that make the male heroes engaging and unique, such as in the romance of Ketil and Hrafnhild in Ketil 
Trout. Whether the reader is meant to pass judgement on these women, or just enjoy them as entertainment, these sagas are to be understood as stories of olden times, and are not necessarily meant to be realistic. Transgressing women in the fornaldarsögur are one of the most interesting literary aspects of the genre. 


\section{Bibliography}

\section{$\underline{\text { Primary sources }}$}

\section{Editions}

Gordon, E.V. An Introduction to Old Norse. $2^{\text {nd }}$ Ed. rev. A.R. Taylor. Oxford: Clarendon, 1957.

Grimstad, Kaaren (ed). Völsunga sage. Saarbrucken: AQ-Verlag, 2000.

Jack, George (ed.). Beowulf: A Student Edition. New York: Oxford, 1994.

Jónsson, Guðni and Bjarni Vilhjálmsson (eds). Fornaldarsögur Norðurlanda. Vols 1-3. Reykjavík: Bókaútgáfan Forni: 1943-4.

Jónsson, Guðni and Bjarni Vilhjálmsson (eds). Fornaldarsögur Norðurlanda. Retrieved 15 June 2009 from Perseus Collection: Germanic Materials. URL http://www.perseus.tufts.edu/hopper/collection.jsp?collection=Perseus:collection:Ge rmanic

Jónsson, Guðni (ed.). Eddukvaði Samundar-Edda. Akureyri, Iceland: Islendingasagnautgafan, 1954. Retrieved 15 June 2009 from Heimskringla. URL http://www.heimskringla.no/wiki/Eddukvæði

Jónsson, Guðni (ed.). Thithreks saga af Bern. Vols 1-2. Reykjavik:

Islendingasagnautgafan, 1954.

Jónssson, Guðni (ed.). Íslendinga sögur. Akureyri, Iceland: Íslendingasagnáutgáfan, 1953. Retrieved 15 June 2009 from Heimskringla. URL

http://www.heimskringla.no/wiki/\%C3\%8Dslendinga_s\%C3\%B6gur

Pope, John C. (ed.). Eight Old English Poems. $3^{\text {rd }}$ ed. rev. R.D. Fulk. New York and London: Norton, 2001.

Saxo Grammaticus. Saxonis Gesta Danorum. Ed. J. Olrik and H. Raeder. Hauniae: Levin \& Munksgaard, 1931-.

Sturluson, Snorri. Edda Snorra Sturlusonar. Ed. Guðni Jónsson. Akureyri, Iceland: Prentverk Odds Bjornssonar, 1954. Retrieved 15 June 2009 from Heimskringla.

URL http://www.heimskringla.no/wiki/Edda_Snorra_Sturlusonar

Sturluson, Snorri. Heimskringla eða Sögur Noregs konunga. Ed. N. Linder and H.A. Haggson. Uppsala: W. Schultz, 1869-72. Retrieved 15 June 2009 from

Heimskringla. URL http://www.heimskringla.no/wiki/Heimskringla 


\section{Translations}

\section{Fornaldarsögur}

Anderson, Rasmus B. and Jón Bjarnason (trans.). Viking Tales of the North.

Chicago: S.C. Griggs and Co., 1877.

Anderson, George K. (trans.). The Saga of the Volsungs, together with excerpts from the Nornageststhattr and three chapters from the Prose Edda. Newark: University of Delaware Press, 1982.

Bachman, W. Bryant, Jr and Guðmundur Erlingsson (trans). Six Old Icelandic Sagas. Lanham, Maryland: University Press of America, 1993.

Bachman W. Bryant, Jr and Guðmundur Erlingsson (trans). The Sagas of King Half and King Hrolf. Lanham, Maryland: University Press of America, 1991.

Bachman, W. Bryant, Jr (trans.). Forty Old Icelandic Tales. Lanham, Maryland: University Press of America, 1992.

Byock, Jesse L. (trans.). The Saga of the Volsungs. London: Penguin, 1999.

Byock, Jesse L. (trans.). The Saga of King Hrolf Kraki. London: Penguin, 1998.

Chappell, Gavin (trans.). The Saga of Ketil Trout. Retrieved 15 June 2009 from Northvegr Foundation. URL http://www.northvegr.org/lore/oldheathen/011.php

Chappell, Gavin. (trans.). Of the Kings of the Uplands. Retrieved 15 June 2009 from Northvegr Foundation. URL http://www.northvegr.org/lore/oldheathen/016.php

Edwards, Paul and Hermann Pálsson. Arrow-Odd: A Medieval Novel. New York: New York University, 1970.

Hardman, George L. (trans.). Of Fjornjot and his Kinsmen. Retrieved 15 June 2009 from Northvegr Foundation. URL http://www.northvegr.org/lore/oldheathen/073.php

Pálsson, Hermann and Paul Edwards (trans.). Göngu-Hrólfs Saga. Toronto: University of Toronto Press, 1980.

Pálsson, Hermann and Paul Edwards (trans.). Hrolf Gautreksson, a Viking Romance. Toronto: University of Toronto Press, 1972. 
Pálsson, Hermann and Paul Edwards (trans.). Gautrek's Saga and other medieval tales. London: University of London Press, 1968.

Pálsson, Hermann and Paul Edwards (trans.). Seven Viking Romances. London: Penguin, 1985.

Pálsson, Hermann and Paul Edwards (trans.). Vikings in Russia. Edinburgh:

Edinburgh University Press, 1989.

Schlauch, Margaret (trans.). The Saga of the Volsungs; The Saga of Ragnar Lodbrok together with the Lay of Kraka. New York: AMS Press, 1978.

Tolkien, Christopher (ed. and trans.). The Saga of King Heidrek the Wise. London: Nelson and Sons, 1960.

Tunstall, Peter (trans.). The Tale of Ragnar's Sons. Retrieved 15 June 2009 from Northvegr Foundation. URL http://www.northvegr.org/lore/oldheathen/055.php

Tunstall, Peter (trans.). The Tale of Eirek the Traveller. Retrieved 15 June 2009 from Northvegr Foundation. URL http://www.northvegr.org/lore/oldheathen/032.php

Tunstall, Peter (trans.). The Saga of Grim Shaggy-Cheek. Retrieved 15 June 2009 from Northvegr Foundation. URL

http://www.northvegr.org/lore/oldheathen/049.php

\section{Riddarasögur}

Kalinke, Marianne E. (ed.). Norse Romance. Vol. 1: The Tristan Legend. Cambridge: D.S. Brewer, 1999.

Kalinke, Marianne E. (ed.). Norse Romance. Vol. 2: The Knights of the Round Table. Cambridge: D.S. Brewer, 1999.

Kalinke, Marianne E. (ed.). Norse Romance. Vol. 3: Harra Ivan. Cambridge: D.S. Brewer, 1999.

Schach, Paul (trans.). The Saga of Tristram and Ísönd. Lincoln: University of Nebraska Press, 1973.

\section{Eddas}

Larrington, Carolyne (trans.). The Poetic Edda. New York: Oxford, 1996.

Sturluson, Snorri. Edda. Trans. Anthony Faulkes. London: Everyman, 1987. 


\section{Islendingasögur}

Cook, Robert (trans.). Njal's Saga. London: Penguin, 2001.

Fox, Denton and Hermann Pálsson (trans). Grettir's Saga. Toronto: University of Toronto Press, 1974.

Thorsson, Örnólfur (ed.). The Sagas of the Icelanders: A Selection. London: Penguin, 2001.

\section{Other primary texts}

Burgess, Glyn S. and Keith Busby (trans). The Lais of Marie de France. Harmondsworth, Middlesex: Penguin, 1986.

Gantz, Jeffrey (trans.). The Mabinogion. Harmondsworth, Middlesex: Penguin, 1976.

Haymes, Edward R. (trans.). The Saga of Thidrek of Bern. New York: Garland, 1988.

Heaney, Seamus (trans.). Beowulf. London: Faber and Faber, 1999.

Hollander, Lee M. (trans.). The Skalds. Ann Arbor: University of Michigan Press, 1968.

Murdoch, Brian O (trans.). Kudrun. London: Everyman, 1987.

Saxo Grammaticus. The History of the Danes. Vols 1-2. Trans. Peter Fisher, Ed. Hilda Ellis Davidson. Cambridge: D.S. Brewer, 1979-80.

Simpson, Jacqueline. Icelandic Folktales and Legends. London: B.T. Batsford Ltd, 1972.

Sturluson, Snorri. Heimskringla. Part Two: Sagas of the Norse Kings. Trans. Samuel Laing. London: J.M. Dent, 1961.

Wagner, Richard. Das Rheingold. Dir. Patrice Chéreau, Bayreuth 1976. DVD copyright Unitel 1980, Philips Classics 1988.

Wagner, Richard. Die Walküre. Dir. Patrice Chéreau, Bayreuth 1976. DVD copyright Unitel 1980, Philips Classics 1988. 
Wagner, Richard. Siegfried. Dir. Patrice Chéreau, Bayreuth 1976. DVD copyright Unitel 1980, Philips Classics 1988.

Wagner, Richard. Götterdämmerung. Dir. Patrice Chéreau, Bayreuth 1976. DVD copyright Unitel 1980, Philips Classics 1988.

\section{$\underline{\text { Secondary Sources }}$}

Alano, Robert A. 'The Role of women in Anglo-Saxon culture: Hildeburh in Beowulf and a curious counterpart in the Volsunga Saga'. English Language Notes 32.1 (1994): 1-10. Regents of the University of Colorado, 1995.

Anderson, Sarah M. and Karen Swenson (eds). Cold Counsel: women in Old Norse Literature and Mythology. New York: Routledge, 2002.

Anderson, Theodore M. The Legend of Brynhild. Islandica XLIII. Ithaca and London: Cornell University Press, 1980.

Archibald, Elizabeth. 'Gold in the Dungheap: incest stories and family values in the Middle Ages'. Journal of Family History 22.2 (1997): pp. 133-149.

Bitel, Lisa M. Land of Women: Tales of Sex and Gender from Early Ireland. Ithaca, New York: Cornell University Press, 1996.

Boberg, Inger Margrethe. Motif-Index of early Icelandic literature. Copenhagen: Munksgaard, 1966.

Byock, Jesse. Viking Age Iceland. Harmondsworth, Middlesex: Penguin, 2001.

Byock, Jesse. Medieval Iceland: Sagas, Society and Power. Berkeley and Los Angeles, California: University of California Press, 1988.

Byock, Jesse. Feud in the Icelandic Saga. Berkeley: University of California Press, 1982.

Donahue, Charles. 'The Valkyries and the Irish War-Goddesses'. Publications of the Modern Language Association 56.1 (1941): pp. 1-12.

Dumézil, Georges. From Myth to Fiction: the Saga of Hadingus. Chicago and London: The University of Chicago Press, 1973.

Gallo, Lorenzo Lozzi. 'The Giantess as Foster-Mother in Old Norse Literature'. Scandinavian Studies 78.1 (2006): pp. 1-19.

Gardiner, Edwin. Fornar Smásögur Noregs Kununga Sögum. Reykjavik: 1949. 
Gruber, Loren C. (ed.). Essays on Old, Middle, Modern English and Old Icelandic. Lewiston: The Edwin Mellen Press, 2000.

Hermannsson, Halldór. Bibliography of the Mythical-Heroic Sagas. Islandica V. Ithaca, New York: Cornell University Library, 1912. New York: Kraus Reprint, 1966.

Houwen, L.A.J.R. and A.A. MacDonald (eds). Loyal Letters: Studies on Mediaeval Alliterative Poetry and Prose. Groningen: Egbert Forsten, 1994.

Jesch, Judith. Women in the Viking Age. Woodbridge: Boydell Press, 1991.

Jochens, Jenny. Old Norse Images of Women. Philadelphia: University of Pennsylvania Press, 1996.

Jochens, Jenny. Women in Old Norse Society. Ithaca: Cornell University Press, 1995.

Kalinke, Marianne E. Bridal-Quest Romance in Medieval Iceland. Ithaca: Cornell University Press, 1990.

Kerr, Margaret H., Richard D. Forsyth and Michael J. Plyley. 'Cold Water and Hot Iron: Trial by Ordeal in England'. Journal of Interdisciplinary History 22.4 (1992): pp. 573-595.

Krappe, A.H. 'The Valkyries'. The Modern Language Review 21.1 (1926): pp. 5573.

Lewis, Lillian Lohr. Wild Woman Archetype: Myth, Magic and the Feminine Personality. PhD thesis. Carpinteria, CA: Pacifica Graduate Institute, 1998.

Loth, Agnete. Fornaldarsagas and late medieval romances. Trans. Peter Foote. Copenhagen: Rosenkilde and Bagger, 1977.

McTurk, Rory (ed.). A Companion to Old Norse-Icelandic Literature and Culture. Malden, Massachusetts: Blackwell Publishing, 2005.

Motz, Lotte. 'The Divided Image: A study of the giantesses and female trolls in Norse myth and literature'. The Mankind Quarterly 27.4 (1987): pp. 463-478.

O'Donoghue, Heather. Old Norse-Icelandic Literature: A Short Introduction. Malden, MA: Blackwell Publishing Ltd, 2004. 
Rumball, Jean. Secgas on Searwum: Early Anglo-Saxon Weapons and Warfare. MA thesis. Wellington: Victoria University of Wellington, 2001.

Schofield, William H. 'Signy's Lament'. Publications of the Modern Language Association of America 17.2 (1902): pp. 262-295.

Straubhaar, Sandra Ballif. 'Nasty, Brutish and Large: Cultural Difference and Otherness in the Figuration of the Trollwomen of the Fornaldar Sögur'.

Scandinavian Studies 73.2 (2001): pp. 105-24.

Thompson, Stith. Motif-index of folk-literature. Vols 1-6. Bloomington: Indiana University Press, 1955-58.

Welsh, Andrew. 'Doubling and Incest in the Mabinogi'. Speculum 65.2 (1990): 34462.

Werner, Cynthia. Madness and Battle-Fury in Greek and Old Germanic Mythology and Literature. MA thesis. Wellington: Victoria University of Wellington, 2006.

Zeno.org Meine Bibliothek. URL

http://www.zeno.org/Literatur/M/Wagner,+Richard/Musikdramen/Der+Ring+des+N ibelungen/Die+Walk\%C3\%BCre/1.+Akt/3.+Szene

\section{$\underline{\text { Dictionaries }}$}

Collins Latin Dictionary Plus Grammar. Glasgow: HarperCollins Publishers, 1997.

Oxford English Dictonary. Oxford: Oxford University Press, 2009. Retrieved 15 June 2009 from Oxford English Dictionary. URL http://dictionary.oed.com/

Zoëga, Geir T. A Concise Dictionary of Old Icelandic. Oxford: Clarendon Press, 1961. Retrieved 15 June 2009 from Northvegr Foundation. URL http://www.northvegr.org/zoega/index002.php 